\title{
PORADNIK
}

JEZZYKOWY

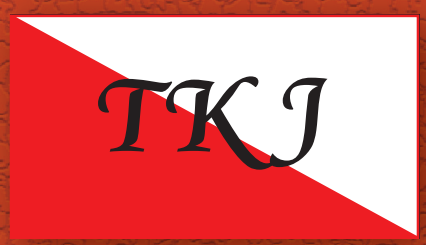

INDEKS 369616

ISSN 0551-5343

NAKŁAD 500 egz.

TOWARZYSTWO KULTURY JĘZYKA

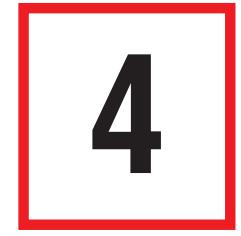

(783) DOM WYDAWNICZY ELIPSA 


\section{PORADNIK JĘZYKOWY}

MIESIECZZNIK ZAŁOŻONY W R. 1901 PRZEZ ROMANA ZAWILIŃSKIEGO

ORGAN TOWARZYSTWA KULTURY JEZYKA

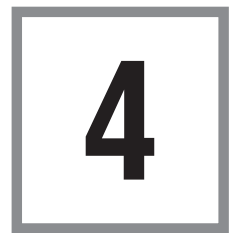

Zarząd Główny ul. Krakowskie Przedmieście 26/28, 00-927 Warszawa Wydział Polonistyki - Uniwersytet Warszawski http://www.tkj.uw.edu.pl

TOWARZYSTWO KULTURY JEZZYKA DOM WYDAWNICZY ELIPSA WARSZAWA 2021 


\title{
KOLEGIUM REDAKCYJNE
}

prof. dr hab. Stanisław Dubisz (redaktor naczelny), dr hab. Jolanta Chojak, dr hab. Wanda Decyk-Zięba (zastępca redaktora naczelnego), dr Ewelina Kwapień, prof. dr hab. Radosław Pawelec, dr Marta Piasecka

\section{RADA REDAKCYJNA}

Prof. dr hab. Stanisław Dubisz (przewodniczący, Warszawa), doc. dr Mirosław Dawlewicz (Wilno - Litwa), prof. dr hab. Andrzej Markowski (Warszawa), prof. dr hab. Alicja Nagórko (Berlin - Niemcy), prof. dr Marta Pančiková (Bratysława - Słowacja), prof. dr hab. Józef Porayski-Pomsta (Warszawa), prof. dr hab. Danuta Rytel-Schwarz (Lipsk - Niemcy), prof. dr Olga Šapkina (Moskwa - Rosja), prof. dr hab. Hélène Włodarczyk (Paryż - Francja)

\author{
Sekretarz Redakcji \\ dr Milena Wojtyńska-Nowotka \\ Redaktor naukowy zeszytu \\ dr Ewelina Kwapień \\ Redaktor językowy \\ Urszula Dubisz \\ THumacz \\ Monika Czarnecka \\ Korektor \\ Halina Maczunder \\ Adres redakcji \\ 00-189 Warszawa, ul. Inflancka 15/198
}

http://www.poradnikjezykowy.uw.edu.pl; e-mail: poradnikjezykowy@uw.edu.pl Dział Handlowy DW ELIPSA: tel. (48) 2263503 01, e-mail: sklep@elipsa.pl Księgarnia internetowa: http://www.elipsa.pl

Czasopismo jest rejestrowane na listach ERIH i IC Master List, indeksowane - w bazach Scopus, CEEOL, Pol-index, Scholar Google

Zeszyt opublikowany w wersji pierwotnej

(C) Copyright by Towarzystwo Kultury Języka and Dom Wydawniczy ELIPSA, Warszawa 2021

PL ISSN 0551-5343

Ark. wyd. 7,3. Ark. druk. 6,25. Papier offsetowy 80 g/m² 


\section{W ZESZYCIE}

- Zachodzące współcześnie zmiany sytuacji komunikacyjnej, rozwój mediów społecznościowych, komercjalizacja sportu powoduja przyśpieszoną ewolucję języka sportu jako odmiany polszczyzny ogólnej. Przyczynia się to m.in. do zaniku granic między dotychczas wyróżnianymi podtypami tego wariantu komunikacyjnego języka.

- Profesjonalizmy sportowe, które przechodzą do słownictwa języka ogólnego, to zjawisko charakterystyczne dla współczesnej polszczyzny; w dużej mierze jest to spowodowane przez media, które propagują modę na sport i wiąże się z popularnościa poszczególnych dyscyplin sportowych.

- Analizy tekstów (mówionych i pisanych) dziennikarzy sportowych wskazują na to, że ich medialny charakter znajduje niejednokrotnie odzwierciedlenie w potocznym i oficjalnym rejestrze języka, a zarazem sa dowodem na to, że wielu dziennikarzy telewizyjnych, radiowych, internetowych i prasowych poszukuje własnego stylu wypowiedzi.

- Słownictwo różnych dziedzin sportu, w tym m.in. wyścigów konnych, ma w dużej mierze charakter zapożyczeń z języków obcych; procesy adaptacji tego słownictwa do systemu językowego polszczyzny są wyraźne w leksyce $z$ tego zakresu w okresie 20-lecia międzywojennego.

- Ważną kwestią natury metodologicznej w słowniku ortoepicznym jest wprowadzanie informacji pragmatycznej; tradycyjnie służą temu kwalifikatory, jednakże niejednokrotnie zadania słownika wymagaja tego, by była ona przedstawiona w sposób opisowy lub w postaci haseł tematycznych.

\section{$* * *$}

Język sportu - mediolingwistyka - komentarz sportowy - profesjonalizmy sportowe - mówione warianty wypowiedzi - konstrukcje porównawcze - zapożyczenia leksykalne - słownik ortoepiczny - norma językowa.

Red. 


\section{SPIS TREŚCI}

\section{ARTYKUŁY I ROZPRAWY}

Beata Grochala: Język sportu w perspektywie mediolingwistycznej

- zarys problematyki

Anna Niepytalska-Osiecka: Stadiony świata, żadło i o błysk szprychy.

Profesjonalizmy sportowe na materiale rejestrowanym przez Wielki słownik

języka polskiego PAN

Mariusz Koper: Nokaut jest tu nieunikniony jak zmarszczki po sześćdziesiątce.

Kilka uwag o konstrukcjach porównawczych w mówionych wariantach

wypowiedzi dziennikarza sportowego Andrzeja Kostyry

Milena Wojtyńska-Nowotka: Zapożyczenia w słownictwie wyścigów konnych w dwudziestoleciu międzywojennym (na podstawie czasopisma

„Jeździec i Hodowca”)

Dorota Zdunkiewicz-Jedynak: Informacja pragmatyczna w słowniku ortoepicznym.

Stan obecny i potrzeby

\section{OBJAŚNIENIA WYRAZÓW I ZWROTÓW}

Magdalena Smoleń-Wawrzusiszyn: Czy grupa może być średniowalna?

Głos w sporze o nowy termin w matematyce

\section{RECENZJE}

Marta Piasecka: Przemysław E. Gębal, Władysław T. Miodunka, Dydaktyka i metodyka nauczania języka polskiego jako obcego, Warszawa 2020

SŁOWA I SŁÓWKA

S.D.: Społem, społeczność, społeczeństwo

BIOGRAMY I WSPOMNIENIA

Elżbieta Wierzbicka-Piotrowska: Teresa Iglikowska (1926-2021) 


\section{CONTENTS}

\section{PAPERS AND DISSERTATIONS}

Beata Grochala: Language of sport from the medialinguistic perspective: outline of the issue

Anna Niepytalska-Osiecka: Sport professionalisms on the material recorded by Wielki słownik jezyka polskiego PAN (Polish Academy of Sciences Great Dictionary of Polish)

Mariusz Koper. Knockout is unavoidable here like wrinkles in your sixties. A few comments on the comparative formations in utterances by Andrzej Kostyra, a sports journalist

Milena Wojtyńska-Nowotka: Borrowings in the horse-racing vocabulary of the interwar period (on the basis of the „Jeździec i Hodowca” ("Rider and breeder") magazine)

Dorota Zdunkiewicz-Jedynak: Pragmatic information in an orthoepic dictionary. Current state and needs

\section{EXPLANATIONS OF WORDS AND EXPRESSIONS}

Magdalena Smoleń-Wawrzusiszyn: Can a group be średniowalny (amenable)? An opinion in a dispute about a new term in mathematics

\section{REVIEWS}

Marta Piasecka: Przemysław E. Gębal, Władysław T. Miodunka, Dydaktyka $i$ metodyka nauczania języka polskiego jako obcego (Didactics and methodology of teaching Polish as a foreign language), Warszawa 2020

\section{WORDS AND EXPRESSIONS}

S.D.: Społem (together), społeczność (community), społeczeństwo (society)

BIOGRAPHICAL NOTES AND REMINISCENCES

Elżbieta Wierzbicka-Piotrowska: Teresa Iglikowska (1926-2021) 


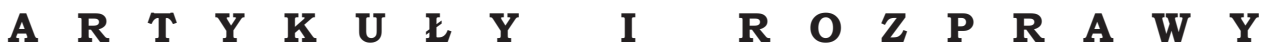

Beata Grochala

DOI: 10.33896/PorJ.2021.4.1

(Uniwersytet Łódzki,

e-mail: beata.grochala@uni.lodz.pl)

ORCID: 0000-0002-3885-8964

\section{JEZZYK SPORTU \\ W PERSPEKTYWIE MEDIOLINGWISTYCZNEJ - ZARYS PROBLEMATYKI}

Badania nad językiem sportu to obszar lingwistyki, który nie został dotychczas wystarczająco poznany. Dzieje się tak z kilku powodów. Po pierwsze, jest to język, który istnieje w bardzo wielu wymiarach, o czym mowa będzie dalej. Po drugie, kompleksowe badania nad nim wymagałyby uwzględnienia bardzo wielu dyscyplin sportowych, ponieważ w obrębie każdej $z$ nich wykształcony został specyficzny repertuar środków językowych, zwłaszcza leksykalnych, służących danej profesji. Po trzecie wreszcie, dziś sport to nie tylko zawody na arenie, ale także ogromne przedsięwzięcie finansowe, co wpływa choćby na sposób mówienia o sporcie.

Celem niniejszego artykułu jest przyjrzenie się współczesnemu językowi sportu w perspektywie mediolingwistycznej, innymi słowy zbadanie, w jaki sposób rozwój mediów przyczynia się do zmian w zakresie badanej odmiany języka. Dla zachowania spójności wywodu należy najpierw zdefiniować sam przedmiot badań, czyli odpowiedzieć na pytanie, czym jest język sportu.

\section{JEZYK SPORTU - PRZEGLĄD DEFINICJI I TAKSONOMII}

Literatura przedmiotu nie dostarcza zwartej, konkretnej definicji języka sportu. Stał się on przedmiotem badań w drugiej połowie XX wieku, ale lingwiści nie wskazywali na zakres ogólny tego pojęcia, koncentrując się raczej na analizach konkretnego materiału. Co prawda w roku 1970 ukazała się książka pod znamiennym tytułem Polskie współczesne słownictwo sportowe, jednak jej autor, Jan Ożdżyński [1970], traktował język sportu jako odmianę socjolektu młodzieżowego, co $z$ perspektywy czasu wydaje się pewnym uogólnieniem. Otwarte pozostaje pytanie, czy o języku sportu można mówić jako o odmiennym socjolekcie, a może profesjolekcie, jednak dziś ograniczanie tej odmiany wyłącznie do młodych użytkowników języka byłoby znaczącym błędem. Pewną próbę upo- 
rządkowania opisu języka sportu odnaleźć można w dwóch publikacjach $z$ przełomu XX i XXI wieku, to jest w artykule Artura Tworka [2000] oraz w tekście Janusza Taborka [2012]. Obaj badacze, germaniści, wskazują przede wszystkim na szeroki zakres omawianego pojęcia, które obejmuje swoim zasięgiem różne grupy zawodowe i środowiskowe związane ze sportem. W pierwszej chronologicznie pracy A. Tworek odwołuje się do niemieckich opracowań leksykograficznych, w których język sportu uznawany jest za

język używany przez społeczność sportową w trakcie aktywności sportowych lub w rozmowach na temat sportu, przy czym członkami owej społeczności sportowej sa zarówno osoby uprawiające sport, jak też nauczyciele, opiekunowie, trenerzy sportowi, sędziowie sportowi, osoby relacjonujace wydarzenia sportowe i wreszcie widzowie wszelkich aktywności sportowych [Tworek 2000, 332].

$\mathrm{Na}$ tej podstawie badacz stwierdza, że język sportu jest zjawiskiem niejednolitym, wielowarstwowym, obejmującym takie pola aktywności komunikacyjnej jak: język przepisów, reguł itp., język naukowy, język relacji, komentarza i publicystyki sportowej, język sportowych programów telewizyjnych, język sportowych programów radiowych, język sportowców i trenerów, język kibiców, język spikera widowiska sportowego, język wywiadu (jako kompilacja języka dziennikarzy i sportowców / trenerów). Te dwanaście pól aktywności komunikacyjnej zdaje się nie wyczerpywać repertuaru sytuacji komunikacyjnych, w których aktywizuje się język sportu. J. Taborek w artykule, który ukazał się 12 lat po tekście A. Tworka, zwraca uwagę na fakt, że zmiany cywilizacyjne, m.in. rozwój Internetu, sprawiły, że w jego opinii należałoby mówić o czterech polach: język przepisów i nauki, język mediów (prasy, radia, telewizji, Internetu), język kibiców, język sportowców, trenerów i sędziów [Tworek 2012]. ${ }^{1}$ W jeszcze innej publikacji poświęconej językowi sportu Mariusz Koper wskazuje na niekompletność wspomnianych klasyfikacji. Badacz konstatuje:

Już jednak na podstawie pobieżnej analizy daje się zauważyć, iż autorzy tych prac nie uwzględnili w swoim wykazie innych odmian charakterystycznych dla tej kategorii bądź też nie poddali ich szczegółowej charakterystyce. Zaliczyć można do nich m.in. coraz częściej analizowany we współczesnych pracach naukowych, a zyskujący na popularności gatunek medialny, jakim jest relacja sportowa emitowana na żywo $\mathrm{w}$ internecie, sportowe serwisy informacyjne, blogi, fora internetowe o tematyce sportowej, wreszcie książki i filmy ukazujące w różnych aspektach tę złożoną problematykę [Koper 2016, 16]. ${ }^{2}$

1 The language of regulation and science; the language of media (press, television, radio, the Internet, mobile); the language of supporters; the language of sportsmen, coaches and referees - tłum. na język polski B.G.

2 Nie do końca zgadzam się z zaprezentowana przez M. Kopera propozycją uzupełnienia klasyfikacji A. Tworka i J. Taborka. M. Koper wskazuje bowiem na konkretne gatunki w obrębie przede wszystkim dziennikarstwa sportowego, 
Na zakończenie rozważań nad wielościa interpretacji terminu język sportu warto przytoczyć taksonomię Julii Murrmann [2015]. Na podstawie wspomnianych powyżej koncepcji, ale także opierając się na publikacjach A. Burkhardta [2006] i M. Lewandowskiego [2008] odnoszacych się jedynie do języka piłki nożnej, badaczka podzieliła socjolekt sportowy (ten termin jest przez nia używany wymiennie $z$ terminem jezyk sportowy) na odmianę wewnątrzśrodowiskowa (język zawodników, kibiców, trenerów, przepisów, literatury fachowej etc.) oraz odmianę medialna (język sprawozdawców, komentatorów, dziennikarzy prasowych itd.). W obrębie obu tych warstw J. Murrmann wskazała na pododmiany związane $z$ kanałem przekazu, tj. jezzyk mówiony i język pisany. Ta próba uporządkowania podziałów w języku sportu warta jest odnotowania, jednak wydaje się, że zbyt łatwo zostały tu postawione linie demarkacyjne między poszczególnymi płaszczyznami - nie uwzględniono w pełni złożonej sytuacji komunikacyjnej związanej z funkcjonowaniem języka sportu we współczesnym świecie, o czym mowa będzie poniżej.

Zaprezentowane powyżej próby opisania obszarów dotyczacych języka sportu pokazują, że jest to język wielowarstwowy, niehomogeniczny. Warstwę najbardziej zróżnicowaną stanowi bez wątpienia leksyka. Ta różnicowana jest przede wszystkim ze względu na dyscyplinę sportu, której dotyczy, ale także sytuację nadawczo-odbiorcza (relacja trener - zawodnik a relacja dziennikarz - widz). Jak wspomniano, leksyka należy do najwcześniej i najlepiej zbadanych elementów języka sportu. Trzeba pochylić się na moment nad wymienioną już pracą Jana Ożdżyńskiego. Choć została ona opublikowana w 1970 roku, a więc 50 lat temu, to pewne zawarte w niej uwagi maja charakter ponadczasowy. Autor wydzielił bowiem m.in. dziesięć obszarów tematycznych, które da się wyodrębnić w języku sportu niezależnie od dyscypliny. Sa to nazwy: miejsc rywalizacji sportowej; uczestników imprez sportowych; sprzętu, ubioru zawodników, urządzeń i obiektów sportowych; zawodów, dyscyplin, konkurencji; klubów, stowarzyszeń i organizacji sportowych; kategorii zawodniczych oraz cech czynności i przedmiotów spotykanych w środowisku sportowym; pojęć związanych $z$ organizacją zawodów i przepisami sportowymi; położenia ciała, ruchów i czynności treningowych; stanów psychicznych i fizycznych zawodników; pojęć dotyczących przejawów życia kulturalnego w kręgu środowiska zwiazanego ze sportem [Ożdżyński 1970, 10]. Podział ten śmiało można zastosować do leksyki sportowej także dziś, podobnie jak kryterium językowego opisu słownictwa, na podstawie którego J. Ożdżyński wyróżnia zapożyczenia, neologizmy słowotwórcze, neosemantyzmy oraz specjalistyczne połączenia wyrazowe. Oba sposoby prezentacji leksyki sportowej sprawdzaja się jako narzę-

tymczasem kryterium podziału we wspomnianych wcześniej klasyfikacjach był nadawca rozumiany jako główny użytkownik danego podtypu języka sportu (stąd język zawodników, trenerów, dziennikarzy itp.). 
dzia badawcze również współcześnie. W tym zakresie nic się nie zmieniło - owszem, pewne elementy dominuja, jak np. zapożyczenia, pewne, jak słownictwo zwiazane $z$ przejawami życia kulturalnego środowisk sportowych, maja charakter recesywny, ale to zjawiska właściwe dla leksyki jako takiej, a słownictwo sportowe podlega tendencjom ogólnym. Element, który w mojej opinii najbardziej wpłynał na zmiany w zakresie języka sportu to bardzo szybki rozwój mediów i, co za tym idzie, ogromna popularyzacja sportu.

\section{SPORT A MEDIA}

Mówiąc o sporcie i języku sportu w perspektywie dynamicznej, trzeba pamiętać także o rozwoju mediów, które dla zmian w obrębie sportu i omawianej odmiany języka są kluczowe. Oczywiście sport, a zatem i język go dotyczący, jest znacznie starszy niż media rozumiane jako prasa, radio, telewizja czy Internet. ${ }^{3}$ Jednak po starożytnym zachwycie igrzyskami olimpijskimi trzeba było czekać aż do czasów Piere’a de Coubertina, aby odżył duch olimpizmu i sportowej rywalizacji. Media zaś przyczyniły się do popularyzacji sportu, ale także do jego komercjalizacji. $Z$ drugiej zaś strony duża jest zasługa sportu w zwiększeniu wyników finansowych koncernów medialnych (rywalizują one między sobą o prawa do transmisji największych imprez sportowych, gdyż zawody typu igrzyska olimpijskie czy mistrzostwa świata zapewniają bardzo duże grono odbiorców, a tym samym - reklamodawców). Dotychczasowe analizy języka sportu nie uwzględniały raczej wzajemnych powiązań mediów i sportu. Rozprawa J. Ożdżyńskiego [1970] jest silnie osadzona w typowym dla tamtych czasów nurcie badawczym - strukturalizmie, wiele jest też prac normatywistycznych, które koncentrują się na języku sportu w odmianie medialnej [m.in. Miodek 1974; Podracki 1978; Cockiewicz 1990] bądź też opracowań ściśle leksykologicznych [Nowowiejski 2011]. XXI wiek to $z$ kolei prace o nachyleniu tekstologicznym i pragmalingwistycznym [Polok 2007]. Wydaje się jednak, że mediolingwistyka daje asumpt do nieco innego spojrzenia na język sportu.

\section{JĘZYK SPORTU A MEDIOLINGWISTYKA}

Mediolingwistyka w założeniu ma stanowić interdyscyplinarne spojrzenie na język, uwzględniające przede wszystkim dorobek nauk o mediach. Jest to jednak spojrzenie językoznawcze, jak pisze bowiem B. Skowronek:

3 Sport był obecny w mediach od początku ich powstania, o czym obszernie pisze Войтик [2017]. 
media wpływaja (niedeterministycznie) na konceptualizowanie zjawisk rzeczywistości, rozumienie ich, wartościowanie i następnie werbalne określanie (poprzez charakterystyczne dla swoich przekazów konstrukcje językowe) [Skowronek 2014, 17].

W innym miejscu krakowski badacz zauważa:

Mediolingwista musi łączyć w swych analizach prymarną dla niego warstwę werbalną komunikatu $z$ szeroko ujmowanym kulturowym, społecznym i rzecz jasna medialnym kontekstem [Skowronek 2013, 95].

Z tych bardzo elementarnych założeń podejścia mediolingwistycznego wynika, że jest to perspektywa metodologiczna skoncentrowana nie tyle na badaniu języka mediów, ile na badaniu wzajemnych relacji i wpływów. W artykule utrzymanym w duchu mediolingwistyki, dotyczącym związku mediów, sportu i języka, Iwona Loewe stawia pytanie: „co ze sportem w mediach może zrobić językoznawca?” i odpowiada na nie: „Przedmiotem oglądu i opisu lingwisty sa teksty stowarzyszone $z$ zawodami powstające na użytek telewizji, a dokładniej masowego widza" [Loewe 2016, 72]. Odpowiedź tę można rozszerzyć na inne media - ważny jest tu masowy odbiorca. Można także postawione przez śląską badaczkę pytanie odwrócić i zastanowić się, co z językiem sportu robią media - i na tak postawione pytanie postaram się pokrótce odpowiedzieć.

1. Zacieranie granicy pomiędzy odmianą wewnątrzśrodowiskowa a medialna języka sportu

We wspomnianej na początku niniejszego tekstu taksonomii języka sportu J. Murrmann zaproponowała uogólnienie dotychczasowych klasyfikacji i dychotomiczny podział języka sportu na odmianę wewnątrzśrodowiskową i medialną. O ile w odniesieniu do języka sportu w wieku XX jest to rozróżnienie trafne, o tyle w XXI wieku może budzić wątpliwości. Przede wszystkim dlatego, że trudno o jasny podział ludzi „władających" językiem sportu na zawodowych dziennikarzy, którzy mieliby posługiwać się odmiana medialną, i osoby ze świata sportu (trenerów, zawodników etc.) związane $z$ odmianą wewnątrzśrodowiskowa. Specjalistyczne dziennikarstwo sportowe, uprawiane przez osoby właściwie do tego przygotowane, powoli przestaje istnieć. Coraz częściej dziennikarstwem parają się ludzie sportu - zawodnicy, trenerzy, ale także działacze sportowi i kibice. Nie ma tu miejsca na rozważania, czy taka działalność można nazwać dziennikarstwem, czy też należałoby określić ją innym mianem. Dla czynionych rozważań najważniejsze jest jedno - mówimy o języku sportu używanym w mediach, czyli pozornie o odmianie medialnej. Jednak dziś zawodnik czy trener współkomentujacy transmisję telewizyjna (np. piłkarze Tomasz Hajto, Artur Wichniarek, lekkoatleta Sebastian Chmara, trener skoczków narciarskich Apoloniusz Tajner), współrelacjonujący zawody w radiu, piszacy felietony do gazet (wspomnę tylko tych publikujacych w „Przeglądzie Sportowym”: Krzysztof Ignaczak 
- siatkarz, Jerzy Dudek, Dariusz Dziekanowski - piłkarze) to element na stałe włączony w medialny przekaz sportowy [por. Grochala 2012]. Język, którym opisuja prezentowane wydarzenia, to bez wątpienia język sportu, ale czy można go nazwać medialnym? Albo precyzyjniej - czy osobom zawodowo związanym ze sportem udaje się oddzielić ów język środowiskowy od języka medialnego? Oczywiście nie ma takiej możliwości, ale też żadne $z$ mediów nie wymaga tego od współpracujących $z$ nim ludzi sportu. Co więcej, ów „język szatni”, „język treningów” jest elementem pożądanym, dzięki niemu wypowiedź staje się autentyczna, ma znamiona spontanicznej, a odbiorca ma wrażenie współuczestniczenia $\mathrm{w}$ omawianym wydarzeniu. A to za sprawa języka, który powoduje skracanie dystansu, włączanie widza, słuchacza, czytelnika do wspólnoty osób zaznajomionych $z$ prezentowana problematyką. Poniżej przedstawiono kilka wypowiedzi medialnych sportowców (występujących w roli dziennikarzy), które zawierają elementy specjalistyczne. Nie sa one jednak w żaden sposób tłumaczone, uznaje się, że odbiorca je zna:

Jest po bloku, lewy atak się otwiera. (...) Zagraliśmy opcja, chyba za szybko Kochanowski pokazał to odejście (...). Zawaliliśmy trochę sprawę z tym zejściem się do przyjęcia. Paweł Zatorski się pcha nie w swoja pozycję [Wojciech Drzyzga, były siatkarz, Polsat]. ${ }^{4}$

Najpierw Vida, Mandzukić wyskoczył, spadając dotknął, spóźniony był. (...) Oddalenie przez Pogbę, zablokowany ten strzał. (...) Dotknięcie piłki przez Vidę było kluczowe. Stały fragment gry, wyćwiczony, na choragiewkę, dwa kontakty, Kante został [Andrzej Juskowiak, były piłkarz,TVP1]. ${ }^{5}$

Fenomenalne zagranie Roberta. Wrócił, odzyskał piłkę, podanie w boczny sektor boiska (...). Oni dalej się nie otwieraja, dalej czekaja w średnim pressingu, wynik mamy otwarty. (...) To jest ewidentnie murawa, on liczył, że ona się odbije, a ona mu siadła, siadła mu pod nogę [Tomasz Hajto, były piłkarz, Polsat]. ${ }^{6}$

Spodziewam się futbolu bardziej spokojnego, mniej kontaktowego (Jerzy Dudek, były piłkarz, „Przegląd Sportowy”]. ${ }^{7}$

Jeśli tylko przyjmujacy dadza Łukaszowi Żygadle dogodne warunki do rozegrania, potencjał w ataku maja niemiłosiernie duży [Krzysztof Ignaczak, były siatkarz, „Przegląd Sportowy"]. ${ }^{8}$

4 Komentarze pochodza $z$ meczu Polska - Stany Zjednoczone rozegranego w ramach mistrzostw świata 29 września $2018 \mathrm{r}$.

5 Komentarze pochodzą $z$ meczu finałowego mistrzostw świata w piłce nożnej Chorwacja - Francja rozegranego 15 lipca 2018 r.

${ }^{6}$ Komentarze pochodza $z$ meczu eliminacyjnego do mistrzostw świata w piłce nożnej Polska - Czarnogóra rozegranego 8 października 2017 r.

7 https://www.przegladsportowy.pl/felietony/przeglad-sportowy-jerzydudek-felieton-o-koronawirusie-or-ekstraklasa-mowi-sprawdzam/w5yv449 [dostęp: 28.04.2020].

8 https://www.przegladsportowy.pl/felietony/krzysztof-ignaczak/krzysztofignaczak-felieton/7zb2g6b [dostęp: 28.04.2020]. 
Powyższe przykłady pokazują, że zmiana relacji nadawczo-odbiorczych w przekazie medialnym wpływa także na rozwój, popularyzację i upowszechnienie jezzyka sportu, który staje się odmiana polszczyzny dostępna dla wszystkich zainteresowanych przedmiotem opisu.

Podobnie dzięki możliwościom mediów, zwłaszcza telewizji, odbiorca ma możliwość „podsłuchiwania” w przerwach wskazówek trenerów, może zajrzeć do szatni zawodników, posłuchać rozmów sędziów - innymi słowy, dzięki mediom język sportu staje się powszechnie dostępny w każdej swojej postaci.

2. Rola mediów społecznościowych w rozwoju języku sportu Media społecznościowe, czyli najogólniej

wszelkie narzędzia oraz ścieżki dwukierunkowej komunikacji, obejmujące szerokie spektrum nowych technologii, w większości opartych na rozwiąaniach internetowych. (...) zestaw bezpłatnych lub prawie bezpłatnych narzędzi i stron internetowych pozwalających określonej społeczności na tworzenie treści i prowadzenie dialogu w sieci [Gwóźdź, Machnik 2014, 13-14],

stanowią dziś podstawę komunikacji. Niezależnie od wieku użytkowników wykorzystywane są tak na płaszczyźnie prywatnej, jak i zawodowej. Także sport to dziedzina, w której odgrywają one znacząca rolę. Mowa tu $z$ jednej strony o licznych profilach facebookowych, kontach twitterowych, instagramowych, kanałach youtubowych klubów, zawodników, organizacji sportowych, $z$ drugiej zaś o dziennikarstwie internetowym, które bardzo intensywnie korzysta $z$ mediów społecznościowych. To kolejna sytuacja, w której zaciera się granica między odmianą wewnątrzśrodowiskowa a odmiana medialna. Dowodem tego jest m.in. gatunek ukształtowany w Internecie, jakim jest relacja on-line - mowa o bezpośredniej relacji $z$ zawodów sportowych zapisywanej $\mathrm{w}$ formie krótkich informacji, uzupełnianych coraz częściej tweetami pochodzaccymi z kont trenerów, sportowców, klubów, ale także dziennikarzy i „zwykłych” użytkowników Internetu, niezwiazanych zawodowo ani ze sportem, ani $z$ dziennikarstwem. ${ }^{9}$ Wszyscy używaja tego samego języka bez zastanawiania się nad stopniem jego zrozumienia przez odbiorcę. Założenie jest bowiem takie, że w dobie powszechnej dostępności informacji nie powinien mieć on problemów ze zrozumieniem każdego przekazu, np.:

9 Więcej na temat sportowej relacji internetowej na żywo w: Grochala 2018. 


\section{Zdjęcie 1. Wykorzystanie tweetu w relacji on-line - print screen fragmentu relacji on-line z meczu Polska - Słowenia rozegranego 19 listopada 2019 r.}

\section{Przemystaw Gajzler}

@przemekgajzler

\section{Co bez Glika, to bez Glika. Po raz drugi Polska rozklepana w obronie \#POLSVN \#POLSLO}

\section{$23: 10-19$ lis 2019}

\section{Zobacz pozostałe Tweety użytkownika Przemysław Gajzler}

Źródło: https://sport.onet.pl/pilka-nozna/kadra/polska-slowenia-relacja-na-zywoi-wynik-live/v81mq85 [dostęp: 28.04.2020].

Innym wymiarem, który pokazuje wpływ mediów społecznościowych na język sportu, jest powierzanie roli komentatora youtuberom. Taka praktykę zastosowała Telewizja Polska podczas transmitowania mistrzostw świata w piłce nożnej w Rosji - oprócz tradycyjnego komentarza prowadzonego przez duet dziennikarz sportowy i ekspert (np. Dariusz Szpakowski i Andrzej Juskowiak) na kanale TVP Sport dostępna była tzw. transmisja alternatywna prowadzona przez dziennikarza Macieja Iwańskiego oraz youtubera Piotra Skowyrskiego, który swoją działalność medialna rozpoczał od amatorskich komentarzy rozgrywek e-sportu (sam był także zawodnikiem). Tym, co różniło oba komentarze nadawane przez tę samą organizację medialną, był przede wszystkim język. Ten, którego używał youtuber, był językiem „klasycznego” komentarza sportowego, jednak wzbogaconym (?) o elementy slangu młodzieżowego, $z$ dużą dozą potoczności, np.:

To jest fifti fifti, nie wiadomo, co będzie. (...) Podchodzi, jakby chciał powiedzieć: Stary, błagam, wybroń to. (...) I tutaj mamy element gamingowy, bo to cieszynka $z$ gry Forttrees. Ja cię, ale teraz będzie ciężko zagrywać Chorwacji [Piotr 'izak' Skowyrski, TVP Sport]. ${ }^{10}$

W obrębie języka sportu, rozumianego wąsko jako sposób opisu konkretnych dyscyplin, w zacytowanych fragmentach tylko jeden wnosi nowy element, a mianowicie nawiazuje do e-sportu zyskującego coraz większa popularność zwłaszcza wśród młodych odbiorców, a to właśnie do nich przede wszystkim kierowany był ów alternatywny komentarz, którego głosem był wspomniany Piotr Skowyrski. Zwracam uwage na określenie głosem, gdyż w ten sposób reklamowała swoje transmisje TVP

10 Komentarze pochodza $z$ meczu finałowego mistrzostw świata w piłce nożnej Chorwacja - Francja rozegranego 15 lipca 2018 r. 
- hasło przewodnie brzmiało: Mundial głosem 'izaka'. Ta próba „transmisji alternatywnej" pokazuje, jak ważnym elementem walki o odbiorcę staje się język przekazu - widz, zwłaszcza młody, nie oczekuje pięknej, bezbłędnej polszczyzny, lecz języka, którym posługuje się na co dzień, który jest mu bliski, zwłaszcza w sferze kontaktów internetowych.

3. Popularyzacja medialna dyscypliny sportu a rozwój języka sportu (na przykładzie snookera)

Jak wielokrotnie wspomniano, sport i media są dziś ze sobą ściśle połączone. Zawody sportowe w najpopularniejszych dyscyplinach sa organizowane przede wszystkim $z$ myśla o widowni telewizyjnej. Jak pisze I. Loewe, medium wzmacnia teatralizacje wydarzeń sportowych, „rozszerza publiczność o telewidownię, dla której przeznaczone sa zabiegi realizatora" [Loewe 2020]. Mediatyzacja sportu ma także swoje następstwa $\mathrm{w}$ rozwoju języka sportu. $Z$ jednej strony stał się on powszechny, dostępny dla każdego, zwłaszcza w odniesieniu do znanych dyscyplin, takich jak np. piłka nożna, siatkówka, lekkoatletyka. $Z$ drugiej zaś media przyczyniają się do wypromowania dyscyplin mniej znanych, często mających charakter lokalny, np. snookera. ${ }^{11}$ To dyscyplina sportu w Europie popularna do niedawna jedynie na Wyspach Brytyjskich. Jednak dzięki bardzo intensywnej kampanii na rzecz popularyzacji snookera prowadzonej przez brytyjska, sportowa stację telewizyjną Eurosport, która ma swoje edycje w poszczególnych krajach starego kontynentu, ta nietypowa dla Polski dyscyplina zyskała także w naszym kraju rzeszę zwolenników - mimo występowania w zawodach jedynie dwóch Polaków, osiagających nie najlepsze rezultaty. ${ }^{12}$ Co $z$ tym się wiąże - język snookera ma bardzo rozbudowana terminologię, która została szybko włączona do języka sportu. Znajdziemy wśród charakterystycznych leksemów takie, które polszczyzna znała już wcześniej dzięki bilardowi, jak łuza, bila, kij bilardowy ${ }^{13}$ itp., ale sa także zupełnie nowe, zapożyczone $z$ języka angielskiego, np. frame (zapisywany także w wersji spolszczonej jako frejm) 'część meczu snookerowego', ${ }^{14}$ break 'suma punktów uzyskanych przez zawodnika w trakcie jednego podejścia do stołu', są również neosemantyzmy, takie jak wózek

11 Warto odnotować, że hasło snooker nie występuje w Uniwersalnym słowniku języka polskiego, pojawia się natomiast w późniejszym o 15 lat Wielkim słowniku języka polskiego (snooker 'popularna w Wielkiej Brytanii gra bilardowa rozgrywana 22 kulami, mniejszymi niż w klasycznym bilardzie, na stole większym niż ten służący do klasycznego bilardu').

12 Kacper Filipiak zajmuje 108., a Adam Stefanów 110. miejsce w rankingu zawodowych graczy (stan na 8 maja 2020 r.)

13 Tu kolejna obserwacja leksykograficzna. Słowa bila i łuza sa rejestrowane tylko przez USJP, nie ma ich wśród dotychczasowych haseł WSJP (stan na 8 maja 2020).

$14 \mathrm{O}$ ile nie podano inaczej, definicje terminów snookerowych maja charakter autorski. 
'wbicie (lub próba wbicia) bili za pomoca bili innej niż biała'; kanon 'kontakt dwóch dowolnych bil', pozycjonowanie 'uderzenie białej bili tak, by była właściwie ustawiona do następnego zagrania', pozycjoner 'przyrząd używany przez sędziego do przywracania bili na właściwa pozycję'15 czy określenia $z$ dziedziny fizyki, które zyskuja wyspecjalizowane znaczenie, $\mathrm{np}$. wsteczna rotacja 'wprawienie bili w ruch obrotowy wsteczny'. Wymienione leksemy nie wyczerpuja bogactwa leksyki snookerowej. Trzeba jednak $z$ pełna stanowczościa stwierdzić, że gdyby nie medialna popularyzacja snookera, język sportu nie wzbogaciłby się tak szybko o nowe elementy, wśród których, co należy podkreślić, nie dominują zapożyczenia, lecz neosemantyzmy. Jednocześnie nowa, ciekawa, łatwa do zapamiętania leksyka sprawiła, że fani snookera bardzo szybko przyswoili ten język i posługuja się nim swobodnie, a telewizyjne transmisje meczów snookerowych gromadzą przed ekranami tysiące widzów.

\section{PODSUMOWANIE}

Perspektywa mediolingwistyczna pozwala spojrzeć na język sportu jako odmianę, która za sprawą mediów stale się rozwija, zyskuje większą liczbę użytkowników, a przede wszystkim staje się elementem łączącym, wspólnotowym. Dzięki szerokiemu dostępowi do mediów zaciera się podział na odmianę wewnątrzśrodowiskowa i medialną. Osób piszących, mówiących o sporcie jest coraz więcej, tak po stronie profesjonalnych dziennikarzy, jak i ludzi sportu czy zwyczajnych kibiców. Kwestia języka kibiców nie została poruszona w niniejszym artykule, ale warto wspomnieć, że także w tym zakresie media zmieniaja dotychczasowe obyczaje. Mowa m.in. o wulgaryzmach, które, niestety, często dominują podczas dopingu stadionowego [por. Dokowicz 2015]. W sytuacji namiastki dopingu, a za taką uważam możliwość umieszczania komentarzy internetowych, uczestniczenia w top czatach itp., wyrazy niecenzuralne, obraźliwe sa usuwane przez moderatorów, co powoduje wzrost kreatywności kibiców i konieczność używania bardziej rozbudowanego słownictwa.

Powróćmy jednak do rozważań nad wzajemnymi związkami mediów, sportu i języka. Wydaje się, że nietypowy czas epidemii i związanej z nią izolacji jeszcze bardziej unaocznił ogromna skalę mediatyzacji współ-

15 W wypadku pozycjonowania i pozycjonera trudno ocenić, na ile sa to neosemantyzmy w stosunku do określeń marketingowo-informatycznych (pozycjonowanie jako 'kreowanie wizerunku marki w sposób wyróżniający ją pośród innych; odpowiednie ustawienie stron internetowych w wyszukiwarkach'; pozycjoner 'osoba, która jest odpowiedzialna za jak najwyższa pozycję danej strony internetowej w wynikach wyszukiwania' - WSJP). Ponieważ w obu dziedzinach są to leksemy nowe na gruncie polszczyzny, można wysnuć hipotezę, że pojawiły się w naszym języku niezależnie od siebie jako słowa utworzone na bazie angielskich odpowiedników. 
czesnego sportu. Ze względu na obostrzenia co do liczby osób przebywajacych w jednym miejscu i zakaz zgromadzeń organizuje się zawody bez udziału publiczności, ale za to $z$ transmisja medialna, która zapewnia zarówno oglądalność, jak i odpowiednie zyski. ${ }^{16}$ Dzięki temu widać, że media determinuja kształt dzisiejszej rywalizacji sportowej, a także sposobu jej prezentacji, opisu, oceny - innymi słowy wpływaja na język sportu i kształtuja go w sposób korzystny dla zdobycia jak największej rzeszy odbiorców. Język sportu stracił swój pierwotny charakter, którego celem było informowanie o zasadach czy przebiegu rywalizacji sportowej. Stał się elementem machiny komercjalizacji i wywierania wpływu na widza, czytelnika, słuchacza, kibica.

\section{Bibliografia}

A. Burkhardt, 2006, Wörterbuch der Fußballsprache, Braunschweig.

W. Cockiewicz, 1990, Czy dziennikarze sportowi powinni się uczyć pisać? (Wnioski $z$ analizy normatywnej tekstów kolumn sportowych trzech dzienników regionalnych: „Gazety Krakowskiej”, „Głosu Robotniczego” i „Trybuny Opolskiej”) [w:] M. Preyzner (red.), Język. Teoria-dydaktyka. Materiały IX Konferencji Młodych Językoznawców - Dydaktyków, Kielce, s. 59-73.

A. Dokowicz, 2015, Wulgaryzmy w języku kibiców polskich, czyli „Polska grać, k.. mać!", Poznań.

S. Dubisz (red. nauk.), 2003, Uniwersalny słownik języka polskiego [USJP], t. I-IV, Warszawa.

B. Grochala, 2012, Dwugłos dziennikarsko-ekspercki-wpływ czynników pragmatycznych na sposób konstruowania komentarza sportowego / relacji sportowej na żywo [w:] Język a Kultura, t. 23: Gatunki mowy w perspektywie kulturowej, s. 199-210.

B. Grochala, 2018, Zmiany $w$ strukturze sportowej relacji internetowej na żywo [w:] B. Skowronek, E. Horyń, A. Walecka-Rynduch (red.), Język a media. Wzory komunikacji we współczesnych mediach, Kraków, s. 84-96.

S. Gwóźdź, B. Machnik, 2014, Media społecznościowe $w$ teorii mediów i teorii społecznej [w:] W. Opioła, M. Popiołek (red.), Media społecznościowe. Nowe formy ekspresji politycznej, Toruń, s. 13-14.

M. Koper, 2016, Język sportu-problematyka badawcza [w:] A. Czapla, M. Koper (red.), Język $i$ sport, Lublin, s. 13-40.

M. Lewandowski, 2008, The Language of Soccer - a Sociolect or a Register?, „Język, Komunikacja, Informacja” 3, s. 21-32.

I. Loewe, 2014, Sport w mediasferze z perspektywy lingwisty, „Postscriptum Polonistyczne" 2 (14), s. 71-91.

I. Loewe, 2020, Sport, medium, dyskurs telewizyjny. Mediolingwistyczne rozważania o wpływie, „Zeszyty Prasoznawcze” 2, s. 31-46.

16 Przykładem moga być zawody snookerowe rozegrane w dniach 11-15 marca 2020 r. w Gibraltarze czy turniej tenisowy w ramach cyklu UTH Pro Match Series, który odbył się w maju 2020 r. na Florydzie. 
J. Miodek, 1974, Szablon metaforyki nagłówków w prasie sportowej, „Acta Universitatis Wratislaviensis, Prace Literackie" XVI, s. 91-102.

J. Murrmann, 2015, Język sportu w ujęciu leksykografów. Analiza terminograficzna wybranych słowników z terminologia sportowa, "Socjolingwistyka” XXIX, s. 245-267.

B. Nowowiejski, 2011, Współczesne polskie słownictwo sportowe $w$ ujęciu normatywnym [w:] Polskie dźwięki, polskie słowa, polska gramatyka (systemteksty-norma-kodyfikacja), Warszawa, s. 263-274.

J. Ożdżyński, 1970, Polskie współczesne słownictwo sportowe, Wrocław-Warszawa-Kraków.

J. Podracki, 1978, Wpływ jezzyka sportowego na inne odmiany polszczyzny, „Kultura Fizyczna” 6, s. 265-269.

K. Polok, 2007, Funkcje języka w języku sportu - próba analizy [w:] Język a komunikacja 17: Język polski XXI wieku: analizy, oceny, perspektywy, Kraków, s. $143-153$.

B. Skowronek, 2014, Mediolingwistyka. Teoria. Metodologia. Idea, „Postscriptum Polonistyczne" 2 (14), s. 15-26.

B. Skowronek, 2013, Mediolingwistyka. Wprowadzenie, Kraków.

J. Taborek, 2012, The language of sport: Some remarks on the language of football [w:] Informed teaching - premises of modern foreign language pedagogy, Piła, s. 237-253.

A. Tworek, 2000, Język sportu - próba definicji (analiza języka polskiego i niemieckiego) [w:] G. Szpila (red.), Język a komunikacja 1: Język trzeciego tysiąclecia, Kraków, s. 331-340.

Е.А. Войтик, 2017, Спортивный медиатекст: Зарождение и развитие (на материале периодических изданий XVIII-XIX вв.), Томск.

P. Żmigrodzki (red.), Wielki słownik języka polskiego [WSJP], wersja on-line: www.wsjp.pl [dostęp: 08.05.2020].

\section{Language of sport from the medialinguistic perspective: outline of the issue}

\section{Summary}

The language of sport has not been a widely researched area in Polish studies. The communication-related change, the development of social media, the commercialisation of sports are the most important factors contributing to transformations noticeable in the discussed language variety. This paper adopts the medialinguistic perspective and attempts to describe the primary directions of changes in the language of sport, with a particular focus on the fading boundaries between the individual subtypes which have been discussed in taxonomies to date.

Keywords: language of sport - media linguistics - media - sports commentary. 


\section{STADIONY ŚWIATA, ŻĄDEO I O BEYSK SZPRYCHY. PROFESJONALIZMY SPORTOWE NA MATERIALE REJESTROWANYM PRZEZ WIELKI SEOWNIK JĘZYKA POLSKIEGO PAN *}

Kilka lat temu Bogusław Nowowiejski zwrócił uwagę na to, że język sportu nie cieszy się szczególnie dużym zainteresowaniem polskich językoznawców [Nowowiejski 2014, 109]. Wydaje się jednak, że słownictwo, którym posługują się ludzie związani ze sportem, a więc sportowcy, fani sportu, dziennikarze sportowi czy amatorzy uprawiający aktywność fizyczna, coraz bardziej przykuwa uwagę badaczy. Począwszy od wczesnych lat dwutysięcznych wzbogaciliśmy się o publikacje omawiające słownictwo sportowe różnych odmian i opisujące socjolekty grup związanych $z$ wieloma ciekawymi dyscyplinami sportowymi. Zajmowano się socjolektem jeździeckim [Pawłowicz 2014], przyjrzano się słownictwu piłkarskiemu [Rosłoń 2011], analizowano mechanizm powstawania socjolektu na przykładzie słownictwa paralotniarzy [Pędzich 2012], powstała także rozprawa o socjolekcie polskich alpinistów [Niepytalska-Osiecka 2014]. Opisano również język transmisji sportowych w ujęciu genologicznym [Grochala 2016]. Powstały artykuły dotyczace języka komentarzy sportowych [Jarosz 2015, 269-282; Wiśnicki 2004, 49-63] oraz przedstawiające wpływ języka sportu na inne odmiany polszczyzny [Zieliński 2002]. Słownictwo nazywające elementy rzeczywistości związanej z aktywnością sportowa i kulturą fizyczną interesowało również młodszych badaczy. Zainteresowanie to zaowocowało napisaniem prac magisterskich i artykułów dotyczacych m.in. anglicyzmów w języku sprawozdawców piłkarskich oraz szerzej - dotyczących zapożyczeń w sportowej odmianie języka [Owczarz 2014; Molińska 2011]. Wymienione przykłady sa - rzecz jasna - jedynie wyborem dostępnej literatury, spis publikacji o języku sportu wzbogaca się bowiem i rozwija.

Językoznawców, którzy przyglądali się rozwojowi leksyki sportowej i socjolektów sportowych, nurtowało pytanie, jak rozumieć termin język

* Publikacja finansowana w ramach programu Ministra Nauki i Szkolnictwa Wyższego pod nazwa „Narodowy Program Rozwoju Humanistyki” w latach 2018-2021, nr projektu $11 \mathrm{H} 180280$ 86, kwota finansowania $1699980 \mathrm{zl}$. 
sportu? Nie jest on bowiem jednorodny i należałoby go pojmować jako odmianę obejmującą liczne pododmiany. Znalazłyby się wśród nich socjolekty grup uprawiających sport amatorsko w czasie wolnym (wspinacze, paralotniarze, nurkowie, kitesurferzy, osoby praktykujące jogę), profesjolekty sportowców zawodowych (piłkarze, siatkarze, tenisiści, kolarze, lekkoatleci itp.), profesjolekty komentatorów i dziennikarzy sportowych, a może także profesjolekty trenerów, instruktorów fitness, nauczycieli jogi. Pewnie należałoby także wyodrębniać i badać leksykę używana przez fanów i kibiców różnych dyscyplin sportowych, czym niektórzy badacze już się zajmowali, nie tylko w aspekcie lingwistycznym, lecz także na przykład - w perspektywie socjologicznej [Dudała 2004]. O wielowymiarowości języka sportu wypowiadało się wielu językoznawców. Niejednorodność tej odmiany podkreślał już w latach siedemdziesiątych znawca języka sportu - Jan Ożdżyński [Ożdżyński 1970]. Zaznaczał, że należy do tej odmiany włączać zarówno leksyke tworzoną przez osoby zawodowo zwiazane ze sportem, jak i słownictwo powstające w kręgu kibiców, miłośników programów czy audycji sportowych, a także wśród dziennikarzy sportowych [Ożdżyński 1970]. Julia Murrmann postulowała nawet sformułowanie języki sportów zamiast język sportu. Badaczka proponowała także dobrze uporządkowany podział socjolektu sportowego $z$ uwzględnieniem odmiany wewnątrzśrodowiskowej i medialnej w pisanych i mówionych wariantach [Murrmann 2015, 245-247]. Bez watpienia terminem język sportu trzeba się posługiwać ze świadomościa, że jest on szeroki i nieprecyzyjny.

Szczególnie atrakcyjne wydaje się poznawanie socjolektów i profesjolektów sportowych. To niewatpliwie fascynujące i wciagające badacza zajęcie, o czym przekonała się wielokrotnie pisząca te słowa. Powtarzając za Tomaszem Piekotem, należy zauważyć, że każda analiza nieopisanego dotą socjolektu jest cenna i uzupełnia niekompletna mape polskiej komunikacji społecznej [Piekot 2008]. Wzbogacajace się słownictwo ludzi zwiazanych ze sportem i rozwój nowych socjolektów sportowych - jak się można spodziewać - nie pozostana niezauważone przez badaczy odmian współczesnego języka. Najwięcej uwagi przyciaga $z$ pewnością warstwa leksykalna - to właśnie głównie tą warstwą różnią się socjolekty i profesjolekty od języka ogólnego. Jest to więc obszar, w którym warto szukać językowych osobliwości czy kreatywności słowotwórczej użytkowników danej odmiany języka.

Słownictwo związane ze sportem może być interesujaccym przedmiotem opisu leksykograficznego. Językiem sportu w ujęciu leksykograficznym zajęła się Julia Murrmann. Badaczka analizowała tworzone przez lingwistów i praktyków dwu- i wielojęzyczne słowniki $z$ terminologia sportowa - ich makro- i mikrostrukturę oraz praktyki leksykograficzne wśród twórców tych dzieł [Murrmann 2015].

Elementy o charakterze sportowym trafiają także do słowników ogólnych języka polskiego. Zwykle sa opatrywane kwalifikatorami sygnalizującymi, że zasięg tych jednostek jest ograniczony. Słownictwo za- 
czerpnięte $z$ profesjolektów sportowych stanowi pewną część materiału rejestrowanego przez elektroniczny Wielki słownik języka polskiego PAN pod red. P. Żmigrodzkiego (WSJP PAN). Słownictwo opatrywane kwalifikatorem sport. to obecnie 745 jednostek [dostęp: 8.04.2020]. Słownik ten jest na bieżąco tworzony, można będzie zatem - w miarę poszerzania zasobu - obserwować ewentualny przyrost jednostek o charakterze sportowym. Dla porównania Słownik języka polskiego pod red. Witolda Doroszewskiego (SJPDor) notuje 265 jednostek kwalifikowanych jako sportowe zestawienia terminologiczne, a Uniwersalny słownik języka polskiego pod red. nauk. Stanisława Dubisza (USJP) rejestruje 1580 haseł sportowych [Nowowiejski 2011, 163-164].

W prezentowanym artykule chciałabym zwrócić uwagę na warstwę słownictwa sportowego, którą oznacza się w WSJP PAN podwójnym kwalifikatorem sport. pot. Twórcy słownika przypisuja ów podwójny kwalifikator jednostkom zaczerpniętym ze sportowych profesjolektów. Abstrahuję więc od sportowych terminów, które w WSJP PAN oznacza się kwalifikatorem sport. Sa to jednostki takie jak na przykład:

- meczbol 'zagranie piłka, które pozwala zwycięzcy uzyskać jednopunktową przewage i wygrać mecz tenisa, tenisa stołowego lub siatkówki';

- wykrok'postawa, która polega na wysunięciu jednej nogi do przodu')

czy zestawienia terminologiczne takie jak:

- latanie precyzyjne 'dyscyplina sportowa, obejmujaca kilka konkurencji, takich jak lot po ustalonej trasie według określonego planu i ladowanie jak najbliżej wyznaczonego punktu, w których uczestnicza piloci małych jednoosobowych samolotów';

- kombinacja alpejska 'dyscyplina sportowa, na która składaja się dwie konkurencje: zjazd na nartach i dwa przejazdy slalomu, wszystko oceniane łaczni e').

Interesuja mnie natomiast te elementy, które narodziły się wśród profesjonalistów zwiąanych ze sportem, ale sa stosowane w nieformalnym wariancie komunikacji. Przyglądam się zatem wybranym, ciekawym pod względem sposobu utworzenia, profesjonalizmom - elementom leksykalnym, którymi posługuja się zawodowcy w sytuacjach nieoficjalnych. Ciekawia mnie także powody, dla których tego typu leksyka trafia do słownika ogólnego.

Warto w tym miejscu wspomnieć ogólnie o koncepcji stosowania kwalifikatorów środowiskowych przyjętej w WSJP PAN. Jednym $z$ kwalifikatorów stosowanych przez twórców słownika do oznaczania słownictwa środowiskowego jest kwalifikator środ. WSJP PAN rezerwuje go jednak dla jednostek wywodzących się $z$ odmian językowych środowisk połączo- 
nych więzami niezawodowymi. Jak pisze Jakub Bobrowski, przedstawiając sposoby kwalifikowania leksyki środowiskowej w słowniku,

zadaniem kwalifikatorów środowiskowych jest informowanie o tym, że dana jednostka leksykalna nie jest używana powszechnie, nawet w ramach normy potocznej, lecz podstawowy zakres jej funkcjonowania ogranicza się do pewnej, ściśle określonej grupy społecznej. Od razu należy zaznaczyć, że chodzi tu o zespoły ludzkie powiazane nieformalnymi więzami, takimi jak wiek, wspólne zainteresowania, poglądy, przynależność do jakiejś subkultury [Bobrowski 2018, 68-69].

Według przyjętej koncepcji leksyka zawodowa (nawet w swym nieoficjalnym wariancie, tj. mieszczacca się w obszarze tzw. profesjonalizmów) nie jest zaliczana do środowiskowej, lecz do specjalistycznej [Bobrowski $2018,69]$. Twórcy WSJP PAN - zgodnie $z$ tym, co wypracowali w swych badaniach socjolingwiści - rysują podział między tym, co swoiste dla języka grup środowiskowych a tym, co swoiste dla grup zawodowych. Ponadto koncepcja kwalifikowania słownictwa w WSJP PAN wyraźnie wyodrębnia tę warstwę leksyki sportowej, która nie należy do oficjalnej terminologii. Jest to słownictwo używane przez profesjonalistów w obrębie własnej grupy zawodowej, ale w sytuacjach nieoficjalnych, zgodnie $z$ ujęciem Andrzeja Markowskiego [Markowski 2012, 16]. Wyrazy oznaczone w WSJP PAN kwalifikatorem sport. pot. należy traktować jako sportowe profesjonalizmy. Prócz tego, że sa stosowane przez zawodowców w sytuacjach nieformalnych, zwykle maja też nacechowanie ekspresywne.

Analizując definicje wyrazów i połączeń wyrazowych oznaczonych w WSJP PAN kwalifikatorem sport. pot., można wyodrębnić kilka profesjolektów, $z$ których te elementy zaczerpnięto. Jest to przede wszystkim profesjolekt piłkarski, kolarski, jeździecki oraz profesjolekt dziennikarzy sportowych. Odnotowane sa także pojedyncze jednostki z profesjolektu bokserów, narciarzy, pływaków czy zawodników rugby - jest tych jednostek mało, bo i dyscypliny, z których się wywodza, cieszą się wśród kibiców dużo mniejszą popularnościa niż piłka nożna.

Badając socjolektalny materiał językowy, można obserwować zjawisko migrowania wyrazów do innych odmian oraz to, jakimi kanałami dochodzi do ich przemieszczania się. Część słownictwa socjolektalnego czy profesjonalnego (a w wypadku tego drugiego zwłaszcza jego wariant nieoficjalny) może zasilać po pewnym czasie i przy sprzyjających warunkach nasz wspólny zasób słownictwa, zwłaszcza w potocznym wariancie komunikacji. O wpływie słownictwa sportowego na inne odmiany oraz o tym, jak język popularnych zawodników sportowych oddziałuje na współczesną polszczyznę pisano już wiele lat temu [m.in. Podracki 1978]. Nie wydaje się wprawdzie, aby proces przenikania tej leksyki następował w sposób masowy, jednak pewne pomysłowo utworzone, ekspresywne jednostki, dotyczacce przy tym modnych w danym czasie dyscyplin sportowych, zyskuja popularność wśród użytkowników polszczyzny ogólnej. 
$\mathrm{Na}$ materiale rejestrowanym przez WSJP PAN również widać, że elementy odnotowane jako sportowe potoczne zaczynaja się pojawiać w tekstach pisanych bądź mówionych o charakterze nieprofesjonalnym - w cytatach z prasy ogólnej czy w wypowiedziach osób niezwiązanych bezpośrednio ze środowiskiem sportowym. Słowo czy połączenie, funkcjonujące do pewnego momentu jedynie w nieoficjalnej komunikacji profesjonalistów lub osób posługujących się socjolektem, wraz z popularyzowaniem jakiejś dziedziny życia przekracza granice socjalnych odmian języka i przenika dalej. Początkowo do zasobu słownictwa fanów danej dyscypliny, potem niekiedy do innych odmian. Dobrym przykładem takiej drogi jest piłkarska cieszynka 'zachowanie zawodnika polegające na okazaniu radości po zdobyciu punktu lub gola w grze', ${ }^{1}$ która w WSJP PAN ma właśnie kwalifikator sport. pot., czyli jest interpretowana jako piłkarski profesjonalizm. Cieszynka używana jeszcze do niedawna jedynie przez piłkarzy, kibiców i komentatorów sportowych zaczęła być zrozumiała dla dużo większej liczby użytkowników polszczyzny, nie tylko tych bezpośrednio zainteresowanych piłką nożna, lecz także tych, do których ów wyraz przebił się przez ogólnopolskie media. Kanałem, który przeniósł cieszynkę do zasobu leksykalnego większej liczby Polaków niż piłkarze, ich fani i komentatorzy sportowi, stał się więc język mediów. Piłka nożna jest dyscypliną na tyle popularną, że i leksyka, która się $z$ tej dyscypliny wywodzi staje się modna. Jak słusznie zauważa Bogusław Nowowiejski, media lansuja modę na zdrowy, sportowy tryb życia, a także modę na zainteresowanie sportem [Nowowiejski 2014].

Sama moda na sport nie spowoduje - rzecz jasna - że każdy element leksykalny przenikający poza profesjolekty sportowe zyska taka sympatię mówiących jak wspomniana cieszynka. Słowo samo w sobie musi być jeszcze atrakcyjne, przyjemnie brzmiące, pomysłowo utworzone albo mieć postać ciekawego neosemantyzmu. Przykładem dość dobrze rozpoznawalnego i używanego przez Polaków zainteresowanych sportem wyrazu o charakterze sportowym jest neosemantyzm zajac kwalifikowany przez WSJP PAN jako sport. pot. i definiowany następujaco: ' $\mathrm{w}$ biegach średnio- i długodystansowych zawodnik, którego zadaniem jest narzucenie jak najszybszego tempa w początkowej fazie biegu, aby późniejszy zwycięzca uzyskał na mecie jak najlepszy czas'. Słowo to wywodzi się $z$ profesjolektu lekkoatletów. Bieganie jest dyscypliną sportowa, która w ostatnim dziesięcioleciu bardzo mocno zainteresowała amatorów. Bieganie stało się modne, biegi zaczęło uprawiać wielu Polaków z różnych grup społecznych i wiekowych. Wielu startuje również $\mathrm{w}$ zawodach biegowych. Niektóre elementy leksykalne, zarezerwowane dotąd dla profesjolektu zawodowych lekkoatletów, stały się więc rozpoznawalne wśród większej liczby użytkowników języka.

1 Wszystkie definicje zaczerpnięto $z$ Wielkiego słownika języka polskiego PAN [www.wsjp.pl]. 
Niektóre sportowe profesjonalizmy z kolei prawdopodobnie nie wyjdą poza artykuły prasowe o tematyce sportowej. Do takich przykładów można zaliczyć notowany przez WSJP jako sport. pot. kolarski frazeologizm o błysk szprychy definiowany 'tak, że w danym wyścigu ktoś był minimalnie szybszy od kogoś'. Element ten pojawia się właściwie tylko $\mathrm{w}$ tekstach prasowych o tematyce sportowej, por. Ewan wygrywa o błysk szprychy w Tour de France [www.niezalezna.pl]; [...] na linii mety o blysk szprychy okazał sie lepszy od Polaka [www.expressbydgoski.pl]. Przegrać $z$ kimś lub wygrać o błysk szprychy - to dość obrazowe i atrakcyjne językowo określenie. Badanie kontekstów pokazuje jednak, że używaja go głównie kolarze i dziennikarze. Zapewne znaja je również fani kolarstwa. Nie wydaje się jednak, by kolarstwo było dyscypliną na tyle ekspansywna medialnie jak choćby piłka nożna czy skoki narciarskie, by ów frazeologizm stał się rozpoznawalny wśród większej liczby użytkowników polszczyzny, tak jak się to stało w wypadku piłkarskiej cieszynki.

Inne jednostki sportowe o charakterze nieoficjalnym pozostana prawdopodobnie zarezerwowane dla komunikacji głównych zainteresowanych, bo dotyczą bezpośrednio działalności zawodowców i głównie dla nich sa użyteczne. Opisują sytuacje ściśle zwiąane $z$ gra, wydarzeniami na boisku, zawodem piłkarza. Za takie należałoby pewnie uznać notowane przez WSJP PAN z kwalifikatorem sport. pot. frazeologizmy takie jak ktoś muruje bramkę 'ktoś skupia się bardziej na obronie własnej bramki niż strzelaniu goli przeciwnikom' lub ktoś założył siatkę komuś ‘ktoś (piłkarz) kopnął piłkę w ten sposób, że przeleciała ona między nogami gracza drużyny przeciwnej'. Stwierdzenia, że ktoś muruje bramkę lub zakłada siatke pojawiaja się w wypowiedziach udzielanych przez piłkarzy dziennikarzom $z$ mediów sportowych, np.:

Lubię atakować, nie lubię się bronić. Gmoch mówi, żeby murować bramkę, ale trener Górski zawsze powtarzał, że należy jedną więcej bramkę strzelić [Tomasz Sikorski, Ligi zagraniczne, „Gazeta Poznańska” 2005-08-29].

W 12 minucie piękna, prostopadła piłkę do Żuchowskiego zagrał Dysko. Żuchowski założył "siatkę" bramkarzowi i zdobył pierwszego gola [Święta wojna dla Ryjewa, „Dziennik Bałtycki” 19.11.2003].

Jeszcze inne zarejestrowane przez WSJP PAN sportowe profesjonalizmy wydają się efemeryczne. Ekspresywne określenie stadiony świata 'w piłce nożnej: bramka zdobyta w niezwykle efektowny sposób, budzący zachwyt mówiącego' według materiału zgromadzonego w omawianym słowniku jest używane w takich sytuacjach, w których w sytuacji codziennej użylibyśmy potocznego frazeologizmu klękajcie narody. Piłkarze, komentatorzy, trenerzy, dziennikarze sportowi mówią czy piszą stadiony świata o sytuacji, w której ktoś strzelił wyjątkowo efektowna bramkę, np.: 
Wracającą od bramki rywali futbolówkę, dopadł na 30. metrze Krzysztof Wierzbicki i strzelił bez namysłu. Piłka wylądowała w siatce, a bramkarz Ceramiki, 21-letni Dariusz Sławiński nie zdołał nawet zareagować: gol jak marzenie, stadiony świata! [Mamy lidera, „Mazowieckie To i Owo” 16.09.2004].

W 85 min Zlatan Ibrahimović w nieprawdopodobny sposób, piętą z około 5 metrów, pokonał Buffona. - Taka taktyka musiała się zemścić. A gol Ibrahimovicia? Stadiony świata - oceniał Marian Pyzałka [Ireneusz Maciaś, Pięta Zlatana, „Słowo Polskie Gazeta Wrocławska" 20.06.2004].

Frazeologizm stadiony świata, jakkolwiek ciekawy, należy do takiej grupy elementów językowych, które dość prędko się zużywaja, przestają być świeże i zastępuje się je nowymi, równie kreatywnie utworzonymi frazeologizmami.

Część profesjonalizmów, które odnajdziemy w WSJP PAN, przyciaga uwage ze względu na duży ładunek ekspresywności. Do tej grupy zaliczyłabym na przykład frazeologizmy nagła śmierć 'metoda rozstrzygania rozgrywek sportowych między dwoma zawodnikami lub drużynami, polegająca na tym, że ta drużyna lub osoba, która pierwsza zdobędzie bramkę albo punkt, wygrywa', ktoś puścit szmate 'ktoś (bramkarz) nie obronił słabego i łatwego do obrony strzału i padła bramka'. Eks presywn e sa też wyrazy plaster 'piłkarz, który podczas meczu stale kryje jednego z zawodników przeciwnej drużyny' albo kombinator 'sportowiec, który bierze udział w kombinacji - konkurencji narciarskiej'. Ekspresywność w wymienionych przykładach uwydatnia się albo ze względu na nacechowanie składników frazeologizmu (śmierć, szmata) albo dzieje się tak, że w wyniku neosemantyzacji zaktualizował się efekt humorystyczny (plaster, kombinator). Naładowane ekspresją sa także elementy żądło i żądlić. Żądło to gracz, którego zadaniem jest atakowanie bramki przeciwnika, żądlenie zaś to właśnie owo atakowanie bramki.

Profesjonalizmy sportowe, które znalazły miejsce w słowniku ogólnym języka polskiego, to element językowej rzeczywistości wart uwagi. Interesujące wydaja się powody, dla których słownictwo - zarezerwowane do pewnego momentu dla specjalistów i ograniczone środowiskowo - pojawia się w słowniku języka ogólnego. Niektóre jednostki, pierwotnie należące do nieoficjalnej komunikacji zawodowych sportowców, stają się na tyle popularne w tekstach i mowie użytkowników języka, że znajdują swoje miejsce w niespecjalistycznych słownikach, rejestrujących stan współczesnej polszczyzny. Wpływają na to niewatpliwie media, lansujące modę na sport. Słowniki zwykle zastrzegaja, że jednostki o charakterze sportowym nie sa używane przez ogół społeczeństwa i opatruja je stosownymi kwalifikatorami. Jednak pojawienie się elementów z profesjo- 
lektów sportowych w słowniku ogólnym, niespecjalistycznym, to może być sygnał, że dany wyraz czy frazeologizm sportowy nabiera pewnej mocy. Zaczyna mieć siłę, by przekraczać granicę swojej odmiany języka i przenikać do zasobów większej liczby użytkowników języka niż tylko zawodowcy. Dzieje się tak zwykle ze względu na popularność dyscypliny i atrakcyjny sposób utworzenia elementu językowego. To, że w słowniku ogólnym zarejestrowano sportowe elementy ekspresywne, wywodzące się $z$ profesjolektów sportowych, świadczy o tym, że znaleziono dostateczny materiał poświadczający ich użycie w różnych źródłach, a frekwencja tych elementów w materiale źródłowym spowodowała, że „zasłużyły” na odnotowanie.

\section{Bibliografia}

J. Bobrowski, A. Czelakowska, M. Grochowski, R. Przybylska, J. Waniakowa, K. Węgrzynek (red.), 2018, Wielki słownik języka polskiego PAN. Geneza, koncepcja, zasady opracowania, Kraków.

J. Dudała, 2004, Fani-chuligani. Rzecz o polskich kibolach, Warszawa.

B. Grochala, 2016, Telewizyjna transmisja sportowa $w$ ujęciu genologii lingwistycznej na materiale meczów piłki nożnej, Łódź.

B. Jarosz, 2015, O języku specjalistycznym $w$ komentarzu sportowym (na przykładzie relacji z meczów siatkarskich), „Socjolingwistyka” nr 29, s. 269-282.

A. Molińska, 2011, O zapożyczeniach $w$ sportowej odmianie języka polskiego na podstawie wywiadów prasowych przeprowadzanych $z$ przedstawicielami środowiska siatkarskiego [w:] Język w komunikacji, t. 1, s. 85-94.

J. Murrmann, 2015, Język sportu w ujęciu leksykografów. Analiza terminograficzna wybranych słowników z terminologia sportowa, "Socjolingwistyka” nr 29, s. 245-267.

A. Niepytalska-Osiecka, 2014, Socjolekt polskich alpinistów. Analiza leksykalno-semantyczna słownictwa, Kraków.

B. Nowowiejski, 2014, Zróżnicowanie polskiej leksyki sportowej (między specjalistyczna terminologia a slownictwem potocznym $i$ środowiskowym), „Poznańskie Spotkania Językoznawcze" nr 28, s. 109-124.

B. Nowowiejski, 2007, Językowy obraz polskiego sportu (na materiale z codziennej prasy ogólnopolskiej i lokalnej) [w:] K. Stępnik, M. Rajewski (red.), Media Studies. Refleksje nad stanem obecnym, Lublin, s. 349-364.

B. Nowowiejski, 2008, Refleksje nad wspótczesna polska leksyka sportowa [w:] M. Rutkowski, K. Zawilska (red.), Nowe zjawiska w języku, tekście i komunikacji, t. II, Olsztyn, s. 23-35.

B. Nowowiejski, 2010, Polskie słownictwo sportowe $w$ świetle słowników XX wieku, „Prace Filologiczne” t. LVIII, s. 283-298.

B. Nowowiejski, 2011, Niektóre językowe skutki feminizacji sportu [w:] A. Piotrowicz, M. Witaszek-Samborska, K. Skibski (red.), Norma językowa w aspekcie teoretycznym i pragmatycznym, Poznań, s. 161-172.

W. Owczarz, 2014, Anglicyzmy w socjolekcie sprawozdawców piłkarskich, Poznań (praca licencjacka).

J. Ożdżyński, 1970, Polskie słownictwo sportowe, Wrocław. 
E. Pawłowicz, 2014, Socjolekt $w$ akcji, czyli próba charakterystyki sytuacji językowej na przykładzie lekcji jazdy konnej [the specialized language of a horse riding lesson] [w:] P. Żmigrodzki, S. Przęczek-Kisielak (red.), Bogactwo wspótczesnej polszczyzny, Kraków, s. 355-364. Kraków.

B. Pędzich, 2012, Jak powstaje socjolekt. Studium słownictwa paralotniarzy, Warszawa.

T. Piekot, 2008, Język w grupie społecznej. Wprowadzenie do analizy socjolektu, Wałbrzych.

J. Podracki, 1978, Wpływ języka sportowego na inne odmiany polszczyzny, „Kultura Fizyczna” nr 6, s. 265-269.

M. Rosłoń, 2011, Mowa trawa. Słownik piłkarskiej polszczyzny, Wrocław.

L. Zieliński, 2002, Wpływ słownictwa sportowego na język polityki [w:] G. Szpila (red.), Język trzeciego tysiaclecia II, t. I: Nowe oblicza komunikacji we wspótczesnej polszczyźnie, Kraków, s. 259-272.

\section{Sport professionalisms on the material recorded by Wielki słownik języka polskiego PAN (Polish Academy of Sciences Great Dictionary of Polish)}

\section{Summary}

This paper discusses the issue of the language elements coming from sport professiolects which have been recorded by the Polish Academy of Sciences Great Dictionary of Polish (WSJP PAN) and labelled as sport. pot. (sport coll.). The author ponders on the reasons why the sport elements which were restricted to professional communication until a point in time are now entering the resource of a larger group of Polish language users and general dictionaries of Polish.

Keywords: language of sport - lexicography - professiolect - sociolect - professionalism. 
(Katolicki Uniwersytet Lubelski Jana Pawła II, e-mail: mkoper@kul.lublin.pl)

ORCID: 0000-0002-9878-0820

\section{NOKAUT JEST TU NIEUNIKNIONY JAK ZMARSZCZKI PO SZEŚĆDZIESIĄTCE. KILKA UWAG O KONSTRUKCJACH PORÓWNAWCZYCH W MÓWIONYCH WARIANTACH WYPOWIEDZI DZIENNIKARZA SPORTOWEGO ANDRZEJA KOSTYRY}

\section{WPROWADZENIE}

Studia nad językiem sportu w Polsce maja już kilkudziesięcioletnią tradycję. Za ich ojca należy uznać Jana Ożdżyńskiego, chociaż pierwsze przyczynkarskie publikacje na ten temat ukazywały się dużo wcześniej. ${ }^{1}$ Współcześnie można mówić o pewnym renesansie badań nad tą odmianą języka. Podyktowane jest to $z$ jednej strony atrakcyjnością tej problematyki, bogactwem korpusowym tekstów sportowych (zarówno mówionych, jak i pisanych), z drugiej zaś modą na językowa potoczność i żywą, bardzo często ekspresywną mową dziennikarzy sportowych, w której można doszukać się wielu interesujących cech idiolektalnych, nierzadko z czasem mających wpływ na ogół zachowań językowych Polaków. Tę ostatnią kwestię widać szczególnie we wpływie leksyki sportowej na inne odmiany polszczyzny. ${ }^{2}$ Obserwujac pisane oraz mówione warianty wypowiedzi dziennikarzy sportowych, należy zatem skonstatować, że ich medialny charakter znajduje czasem odzwierciedlenie w potocznym i oficjalnym rejestrze języka. Ponadto wielu dziennikarzy telewizyjnych, radiowych, internetowych oraz prasowych poszukuje własnego stylu sprawozdawczego. Widać to bardzo często w ich wyszukanych konstrukcjach, innowacjach frazeologicznych, skrzydlatych słowach, peryfrazach, z których

1 Stan badań nad językiem sportu oraz bibliografię prac przedstawiłem w jednym ze swoich artykułów. Zob. M. Koper, Język sportu - problematyka badawcza [w:] A. Czapla, M. Koper (red.), Język $i$ sport, Lublin 2016, s. 13-40. Należy jednak zaznaczyć, iż w ostatnich latach pojawiło się kilkanaście nowych publikacji.

2 J. Podracki, Wpływ słownictwa sportowego na inne odmiany polszczyzny, „Kultura Fizyczna” 1978, nr 6, s. 265-269; L. Zieliński, Wpływ słownictwa sportowego na język polityki [w:] G. Szpila (red.), Język a komunikacja 4. Zbiór referatów $z$ konferencji pt. Język trzeciego tysiąclecia II (Kraków, 28 lutego-2 marca 2002), t. I: Nowe oblicza komunikacji we współczesnej polszczyźnie, Kraków 2002, s. 261-270. 
część jest bardzo oryginalna, inna zaś graniczy $z$ językowym kiczem. ${ }^{3}$ $Z$ pewnością barwny język sportu, jego emocjonalny charakter, kreatywność i wyobraźnia użytkowników sprawia, że coraz częściej staje się on przedmiotem refleksji lingwistycznej.

W ostatnich kilkunastu latach studia nad ta odmiana języka skupiały się głównie na analizie mówionych wariantów wypowiedzi dziennikarzy sportowych. Nieco mniejsza uwaga cieszyły się badania prasowe lub internetowe. Szczególnie w obszarze badań idiolektalnych, czyli tych, które poświęcone są osobliwościom językowym konkretnego dziennikarza sportowego, jest jeszcze wiele materiału do interpretacji. W mniejszym też stopniu autorzy prac $z$ zakresu leksyki sportowej analizowali słownictwo specjalne samych sportowców i kibiców. Należy jednak podkreślić, że i w tym aspekcie luki badawcze sa sukcesywnie zapełniane. Powstaje bowiem coraz więcej prac na temat odmian socjolektalnych poszczególnych dyscyplin sportowych (m.in. piłki nożnej, kolarstwa, siatkówki, skoków narciarskich) oraz języka środowisk kibicowskich. ${ }^{4} Z$ drugiej strony, obserwując współczesne trendy, można zauważyć, iż językoznawcy coraz częściej za cel swoich badań stawiają analizę genologiczną oraz sportowy dyskurs w mediach. ${ }^{5}$ Pojawiaja się wreszcie prace niedotyczace sensu stricto języka sportowego, ale będące niejako owocem lingwistycznej refleksji na tle bieżących wydarzeń sportowych, takich jak igrzyska olimpijskie czy mistrzostwa świata. Tego typu publikacje określam mianem obrzeży języka sportowego. ${ }^{6}$ Podsumowując ten krótki przegląd prac o ję-

3 Zob. B. Grochala, Kicz jako sposób wyrażania emocji (metaforyka radiowych relacji sportowych) [w:] B. Kudra, E. Szkudlarek-Śmiechowicz (red.), Kicz $w$ języku i komunikacji, Łódź 2016, s. 335-342.

4 Można do nich zaliczyć m.in. publikacje Stefana Wiertlewskiego, poświęcone socjolektowi rowerowemu, Wioletty Kochmańskiej o języku siatkówki w odmianie środowiskowo-profesjonalnej i wewnątrzśrodowiskowej czy też prace Katarzyny Gilety-Klępki o języku kibiców. Zob. M. Koper, op. cit., s. 13-40.

5 B. Grochala, Telewizyjna transmisja sportowa jako kolekcja gatunków [w:] D. Ostaszewska, J. Przyklenk (red.), Gatunki mowy i ich ewolucja, t. 5: Gatunek a granice, Katowice 2015, s. 347-355; tejże, Telewizyjna transmisja sportowa w ujęciu genologii lingwistycznej na materiale meczów piłki nożnej, Łódź 2016; I. Loewe, Sport $w$ mediasferze $z$ perspektywy lingwisty, „Postscriptum Polonistyczne" 2014, nr 2 (14), s. 71-91; tejże, Sport, medium, dyskurs telewizyjny. Mediolingwistyczne rozważania o wpływie, "Zeszyty Prasoznawcze" 2020, t. 63, nr 2 (242), s. 31-46.

6 Bardzo często sa to prace $z$ zakresu poprawności językowej, kultury języka i stylistyki. Zob. Z. Gałecki, Slavek i Slavko - nazwy maskotek Mistrzostw Europy w Piłce Nożnej 2012, „Roczniki Humanistyczne” 2012, t. LX, z. 6, s. 87-95; tegoż, „Czyste szaleństwo”- współczesna piosenka okolicznościowa. Liber i zespót InoRos [w:] J. Kuć, K. Wojtczuk (red.), Język a muzyka. Ujęcie filologiczne i muzykologiczne, Siedlce 2014, s. 23-29; M. Koper, Polska dawaj! O języku pitkarskiego hasła oraz jego bliższych i dalszych konotacjach, „Poradnik Językowy” 2019, z. 1, s. 95-105. 
zyku sportu, można skonstatować, iż w początkowym okresie refleksji lingwistycznej nad ta odmiana języka dominowało głównie ujęcie strukturalistyczne, w następnych etapach zaś socjolingwistyczne, pragmalingwistyczne, tekstologiczne oraz mediolingwistyczne.

Przedmiotem niniejszego artykułu jest analiza wybranych mówionych wariantów wypowiedzi Andrzeja Kostyry. Materiałem źródłowym wykorzystanym na potrzeby niniejszego szkicu sa relacje $z$ walk bokserskich $z$ ostatnich kilkunastu lat. Zostały one zgromadzone przez autora niniejszego artykułu bądź też wynotowane $z$ wybranych witryn internetowych. ${ }^{7}$ Przywołany w tytule tego tekstu A. Kostyra jest nie tylko popularnym dziennikarzem prasowym, ale też dobrze rozpoznawalnym komentatorem sportowym specjalizującym się głównie w boksie zawodowym oraz w futbolu amerykańskim. Swoją karierę dziennikarska rozpoczą w latach 90. XX wieku, kiedy był korespondentem Telewizji Polskiej na Igrzyskach Olimpijskich w Barcelonie w 1992 roku. Już wtedy relacjonował zmagania bokserskie. W kolejnych latach współpracował m.in. z Wizja Sport i Polsatem Sport. Swoje artykuły zamieszczał również w „Przeglądzie Sportowym”. Obecnie jest szefem działu sportowego w „Super Expressie". Prowadzi także kanał na YouTube o tematyce bokserskiej - Kostyra SE. Ponadto warto odnotować, iż jest autorem pozycji książkowej pt. Walki stulecia. Bohaterowie wielkiego boksu. ${ }^{8}$

$\mathrm{W}$ relacjach $\mathrm{z}$ aren bokserskich A. Kostyra posługuje się barwnym, nieszablonowym i sugestywnym językiem. Ze względu na te cechy część środowiska kibiców określa go mianem Paganiniego sportowego mikrofonu. ${ }^{9}$ Jedna $z$ najbardziej charakterystycznych cech językowych tego dziennikarza jest stosowanie konstrukcji porównawczych. Obserwując bogactwo komparatywów, można zaryzykować stwierdzenie, iż jest to główna i najbardziej rozpoznawalna cecha jego profesjololektu. Wprawdzie nagromadzenie porównań $\mathrm{w}$ relacjach to jeden $z$ podstawowych wyznaczników współczesnego języka sportowego w odmianie środowiskowo-profesjonal-

$7 \mathrm{~W}$ ostatnich kilkunastu latach wielu internautów gromadzi materiał leksykalny wybranych dziennikarzy sportowych. Charakteryzuje się on barwnościa opisu widowisk sportowych, skłonnościa do parodii, humoru. Autorzy odnotowują też w nim błędy językowe. Nierzadko jednak zgromadzony przez nich materiał nie jest do końca wiarygodny oraz rzeczowo bywa słabo udokumentowany. Przy korzystaniu ze źródeł internetowych autor niniejszego tekstu szczegółowo weryfikował autentyczność korpusu wypowiedzi mówionych, opierając się na własnych doświadczeniach oraz obserwacjach transmisji telewizyjnych.

8 A. Kostyra, Walki stulecia. Bohaterowie wielkiego boksu, Kraków 2017.

9 Konstrukcje peryfrastyczne, dzisiaj w języku mediów bardzo modne, są także charakterystyczne dla języka sportowego. Najczęściej wyrażeniami omownymi określani sa sportowcy, rzadziej drużyny, areny sportowe itp. Zob. M. Koper, Peryfrazy w języku komentatorów sportowych, „Roczniki Humanistyczne" 2012, s. 113-122; przedruk [w:] M. Kita, I. Loewe (red.), Język w telewizji. Antologia, Katowice 2016, s. 217-226. 
nej, niemniej jednak w opinii piszacego te słowa nie ma drugiego dziennikarza, który tak często i z takim przywiąaniem posługiwałby się tymi konstrukcjami. Poza tą dominantą w języku A. Kostyry występują również inne wyznaczniki stylowe. Należy do nich m.in. rozbudowana szata metaforyczna, peryfrastyczność wypowiedzi, dygresyjność, skłonność do ironii, sarkazmu, prowokowanie treści drażliwych, łamiących językowe tabu, kolokwialność, naturalistyczne obrazowanie czy też przejawy świadczące o brutalizacji wypowiedzi. Ostatnia $z$ cech ma swoje usprawiedliwienie $\mathrm{w}$ tym, że sam boks zawodowy jest jednym $z$ najbrutalniejszych sportów walki. $Z$ uwagi na ograniczenia redakcyjne omówiona będzie jedynie zróżnicowana warstwa komparatywów w języku A. Kostyry. W dalszej części niniejszego artykułu kolejno zostanie przedstawiona charakterystyka formalna porównań, semantyka komparacji, uwzględniająca człon porównujący i porównywany, funkcja komparatywów oraz próba ich ogólnej oceny. Artykuł kończy krótkie podsumowanie.

\section{STRUKTURA PORÓWNAŃ}

Literatura przedmiotu dotyczaca porównań w tekstach literackich i użytkowych jest bardzo obszerna. ${ }^{10}$ Sukcesywnie pojawiają się nowe opracowania dotyczacce komparatywów. Również język sportu doczekał się kilku pozycji na ten temat. Jedna $z$ kluczowych publikacji jest praca Katarzyny Burskiej, dotyczaca konstrukcji porównawczych jako przejawu językowej kreatywności dziennikarzy sportowych. ${ }^{11} \mathrm{Na}$ rolę kom-

10 Zob. m.in. B. Mikołajczak, Porównania w „Faraonie” Bolesława Prusa, „Studia Polonistyczne” 1976, s. 105-114; D. Buttler, Porównania w twórczości "Żeromskiego [w:] Z. Goliński (red.), Stefan Żeromski. W pięćdziesiata rocznice śmierci. Studia i szkice, Warszawa 1977, s. 258-276; K. Siekierska, Porównania $w$ „Wojnie chocimskiej” Wacława Potockiego i w „Pamiętnikach” Jana Chryzostoma Paska, „Polonica” 1981, t. VII, s. 233-254; Z. Mokranowska, Porównania $z$ „Ogniem i mieczem” Henryka Sienkiewicza [w:] H. Bursztyńska (red.), Henryk Sienkiewicz: tradycja - kreacja - styl, Katowice 1982, s. 114-130; M. Zarębina, Porównania $w$ „Anielce” $i$ „Placówce” Bolesława Prusa, „Polonica” 1990, t. XV, s. 131-144; E. Młynarczyk, Porównanie w powieści W. Myśliwskiego „Kamień na kamieniu”, „Rocznik Naukowo-Dydaktyczny WSP w Krakowie. Prace Językoznawcze" t. VIII, s. 149-155; M. Pietrzak, Rośliny w porównaniach występujacych w „Trylogii” Henryka Sienkiewicza [w:] A. Dąbrowska (red.), Język a kultura, t. 16: Świat roślin w języku i kulturze, red. A. Dabrowska, Wrocław 2001, s. 169-179; M. Majewska, Porównania w „Urodzie życia” Stefana Żeromskiego (materiał badawczy z objaśnieniami), „Prace Filologiczne” 2004, t. XLIX, s. 317-346; U. Sokólska, Porównania charakteryzujace ludzi i zachowania ludzkie $w$ reportażach M. Wańkowicza, „Roczniki Humanistyczne” 2001/2002, z. 6, s. 391-402.

11 Zob. K. Burska, Porównanie jako przejaw językowej kreatywności dziennikarzy sportowych (na materiale z wortalu iGol.pl) [w:] A. Czapla, M. Koper (red.), Język $i$ sport, Lublin 2016, s. 41-59. 
paratywów w odmianie dziennikarsko-sportowej zwróciła także uwagę Karolina Czemplik ${ }^{12}$ i Beata Grochala. ${ }^{13} \mathrm{O}$ porównaniach w relacjach i komentarzach sportowych wspominali też w swoich pracach Mariusz Koper ${ }^{14}$ oraz Beata Jarosz. ${ }^{15}$

Według autorów Słownika terminów literackich porównanie to:

uwydatnienie jakichś właściwości opisywanego zjawiska przez wskazanie na jego podobieństwo do innego zjawiska. Porównanie jest dwuczłonową konstrukcją semantyczna sprzęgnięta wewnętrznie za pomoca wyrażeń: jak, jako, jak gdyby, na kształt, podobny, niby itp. Oba człony odznaczaja się przy tym pewna cecha semantyczna, motywująca porównanie i stanowiąca jego logiczna podstawę, tzw. tertium comparationis. W wyniku porównania zjawisko, o którym mowa, zostaje zinterpretowane poprzez pryzmat zjawiska, $\mathrm{z}$ którym je zestawiono. ${ }^{16}$

Zdaniem Františka Čermáka pełny schemat porównania zawiera następujące elementy: comparandum (przedmiot, zjawisko porównywane), relator (czasownik o szerokiej wartości kategorialnej, np. jest), tertium comparationis (określenie, na czym polega podobieństwo), comparator (łącznik porównania) i comparatum (człon porównujący). ${ }^{17} \mathrm{~W}$ konstrukcjach porównawczych opuszczeniu może ulec każdy z wymienionych wyżej elementów $z$ wyjątkiem comparatum, które jest koniecznym składnikiem każdego porównania.

W pracach polskich autorów, nierzadko zróżnicowanych pod względem metodologicznym oraz terminologicznym, zasadniczo wyróżnia się trzy podstawowe składniki porównania. Pierwszy to człon porównujący, odnoszący się do tego, co porównujemy (comparandum), drugi to człon porównywany, mający związek z tym, do czego porównujemy (comparans) i trzeci określany mianem funktora gramatycznego. Istotne jest również wyodrębnienie tzw. tertium comparationis, czyli wspólnej cechy

12 K. Czemplik, Czasami zaskakujacy, czasami zabawny, ale jakże oryginalny jezyk relacji sportowych Zimowych Igrzysk Olimpijskich Soczi 2014 [w:] K. Burska, B. Cieśla (red.), Kreatywność językowa w przestrzeni medialnej, Łódź 2014, s. 49-58.

13 B. Grochala, Kicz jako sposób wyrażania emocji (metaforyka radiowych relacji sportowych) [w:] B. Kudra, E. Szkudlarek-Śmiechowicz (red.), Kicz w języku i komunikacji, Łódź 2016, s. 335-342.

14 M. Koper, Emocje w języku sprawozdawców sportowych [w:] K. Wojtczuk, V. Machnicka (red.), Rejestr emocjonalny języka, Siedlce 2009, s. 67-76.

15 B. Jarosz, Sposoby wartościowania w wypowiedziach komentatorów siatkarskich [w:] M. Karwatowska, A. Siwiec (red.), Wartości i wartościowanie w badaniach nad językiem, Chełm 2012, s. 142.

16 M. Głowiński, T. Kostkiewiczowa, A. Okopień-Sławińska, J. Sławiński, Słownik terminów literackich, Wrocław 2002, s. 411.

17 Česka přirownání [w:] Slownik české frazeologie a idiomatiky. Přirownání, Praha 1983. Za: Z. Leszczyński, Doświadczenie tekstów sakralnych odbite w obiegowych porównaniach, „Eódzkie Studia Teologiczne” 1994, z. 3, s. 152. 
warunkującej logiczną podstawę znaczeniową członu porównywanego i porównujacego. ${ }^{18}$

Biorąc pod uwagę strukturę, w języku A. Kostry możemy wyróżnić komparatywa proste oraz złożone. Pierwsze składają się najczęściej z jednego bądź dwóch segmentów w członie porównującym i porównywanym. W comparandum ujawniony zostaje podmiot porównania oraz jego cecha, w comparatum zaś obiekt porównujący w postaci wyrażenia dwuskładnikowego (zazwyczaj przymiotnik + rzeczownik, rzeczownik + wyrażenie przyimkowe). Najczęstszym łącznikiem obydwu elementów jest forma zaimkowa jak:

Obrona Tysona śmierdzi jak dworcowa knajpa.

Sosnowski jest solidny jak kościelne drzwi.

Darek chodzi jak tygrys po klatce.

Bardzo często w pierwszym członie porównania pominięte jest comparandum. Przedmiot porównania występuje wówczas $\mathrm{w}$ formie podmiotu domyślnego. Określana jest jednak jego cecha lub czynność, która wykonał. W konstrukcjach tego typu występuje również relator, chociaż i on może zostać usunięty:

Jest wolny jak ketchup.

Walną jak młotem pneumatycznym.

Nie jest sztywny jak pomnik.

Zdarzają się również komparatywa, w których brakuje zarówno relatora, jak i podmiotu porównywanego. Pojawia się jedynie tertium comparationis, tj. wspólna cecha obydwu członów konstytuujących porównanie, relator (w niektórych pracach nazywany też funktorem) oraz rzeczownik pełniący funkcję comparatum:

Zażarty jak bulterier.

Wolny jak ketchup.

Znacznie obszerniejsza grupę stanowia porównania złożone, tj. składające się $z$ więcej niż dwóch składników w comparatum (członie porównującym). W członie porównywanym, nierzadko eliptycznym, występuje jedynie cecha lub czynność podmiotu. Staje się on bardziej czytelny przy uwzględnieniu szerszego kontekstu komentarza sportowego:

Namęczył się jak aktorzy filmów pornograficznych przy dialogach.

Porusza się niezdarnie jak wóz drabiniasty z pijanym woźnica.

Już strzegł zwycięstwa jak rekin następnego posiłku.

18 A. Kudra, Porównanie w poezji Tadeusza Różewicza (lata 1945-1950), „Acta Universitatis Lodziensis. Folia Litteraria Polonica” 2003, 6, s. 314. 
W bogatym repertuarze porównań A. Kostyry pojawiają się również i takie, które mają formę rozbudowaną zarówno w członie porównywanym, jak i porównującym:

On miał takie szanse na przetrwanie tej serii ciosów jak śnieżny bałwan na pustyni. Gołota wstrząsa Sandersem jak barman koktajlem $z$ wódki i miodu.

Lewis unikał walki jak ścigany listem gończym policjantów.

Przed tą walka $z$ Kliczką był odważny jak kogut na własnej grzędzie, odgrażał się, że zleje Kliczkę, który jak twierdzi, ma miękkie serce i szklaną szczękę.

Byrd w zeszłym roku stoczył zaledwie jedną walkę, stąd pojawiły się opinie, że może być zardzewiały jak sprowadzane przez Polaków samochody z Niemiec.

A. Kostyra stosuje również porównania, które mają rozbudowaną dwuskładnikowa strukturę w członie drugim. Składa się on wówczas $z$ typowego comparatum, uzupełnionego o zdanie współrzędnie złożone przeciwstawne lub podrzędnie złożone przydawkowe. Wypowiedzenia te moga dodatkowo charakteryzować całą strukturę porównania lub téz doprecyzowywać jeden $z$ jego członów:

Jest szeroki jak drzwi w kościele, ale nawet te drzwi mają w sobie więcej finezji.

Potężny, szeroki jak drzwi w kościele, ale czasami wydaje się, że drzwi mają w sobie więcej fantazji.

Wyglądał jak prezes jakiegoś banku centralnego, który obniżył oprocentowanie do zera.

W komparatywach zarówno prostych, jak i złożonych - wieloskładnikowych w komponencie porównawczym najczęściej funkcję łącznika przyjmuje zaimek komparator jak. Zdarzaja się jednak konstrukcje, w których łącznikiem jest inny funktor, np. niż:

Potrafi być bardziej paskudny niż przereklamowany wirus świńskiej grypy.

W mówionych wariantach wypowiedzi A. Kostyry można odnotować osobliwe konstrukcje komparatystyczne, które wprawdzie nie zawieraja łącznika porównania, jednak ich wyraźnie dwuskładnikowa budowa (człon porównywany i porównujący) wskazuje na strukturę porównawcza. ${ }^{19}$ Funkcję komparatora pełni tutaj czasownik przypominać:

Twarz Amerykanina przypomina już carpaccio.

Marin jest jednak bardzo powolny. Przypomina wóz wypełniony kapustą.

Połowa twarzy Barrery przypomina krwawa maskę.

Poza figura językowo-stylistyczna, która jest porównanie, w języku mówionym A. Kostyry występują konstrukcje składniowe o charakte-

19 O osobliwych komparatorach pisze m.in. Maria Joka. Zob. M. Joka, Indywidualne warianty comparatora $w$ twórczości Jana Parandowskiego, „Roczniki Humanistyczne" 2001-2002, t. XLIX-L, s. 145-158. 
rze porównawczym. ${ }^{20}$ Nie przyjmują one struktury typowych komparacji, lecz wypowiedzeń podrzędnie złożonych, w których pełne zrozumienie znaczeniowej zawartości zdania nadrzędnego uzależnione jest od umieszczonego na tle porównawczym zdania podrzędnego. Niektóre $z$ wypowiedzeń to struktury wielokrotnie złożone:

Wydaje się, że jest tak silny, że mógłby iść na zderzenie $z$ czołgiem, ze szkodą dla czołgu.

Gołota prezentował się rewelacyjnie, wydawał się tak silny, że mógłby chyba przenieść górę do Mahometa.

On ma tak wielkie doświadczenie, że w jego narożniku mógłby stać nawet Michael Jackson, a on walczyłby tak samo.

Oni momentami poruszają się tak, jakby uciekli $z$ domu starców.

Był porozbijany tak, że można by go hospitalizować w szpitalu dla weteranów wojennych.

Podsumowując tę szkicowo nakreślona problematykę związaną $z$ budową komparatywów, należy zauważyć, iż struktury porównawcze zgromadzone na potrzeby niniejszego artykułu dostarczaja komparacji prostych oraz rozbudowanych zarówno w komponencie porównywanym, jak i porównującym. W materiale językowym nie odnotowano porównań wieloskładnikowych, które w literaturze przedmiotu określane sa mianem homeryckich. Jest to zrozumiałe, gdyż, o czym jeszcze będzie mowa, w języku A. Kostyry dominuja komparatywa potoczne oraz wysoce zindywidualizowane. Te ostatnie, tworzone ad hoc lub przygotowywane wcześniej na użytek widowiska sportowego, wydaja się najbardziej typowe dla tego dziennikarza.

\section{SEMANTYKA PORÓWNAŃ}

W literaturze przedmiotu wyróżnia się porównania potoczne, utarte, szablonowe oraz oryginalne struktury komparatystyczne. Pierwsze sa formacjami stosunkowo łatwymi do zinterpretowania, gdyż opieraja na naszych bezpośrednich doświadczeniach oraz obserwacji otaczajacej nas rzeczywistości. W drugiej grupie mieszczą się porównania nierzadko wykorzystujace odległe i bardzo zaskakujace asocjacje. $Z$ uwagi na swoją oryginalność i wyjątkowość nazywane sa porównaniami poetyckimi. ${ }^{21} \mathrm{~W}$ tekstach medialnych moga one $z$ jednej strony świadczyć o nieszablonowości, oryginalności twórcy, jego kreatywności, kompetencji i wyobraźni językowej, $z$ drugiej jednak strony, $z$ uwagi na swoja pre-

20 Zob. Z. Klemensiewicz, Zarys składni polskiej, Warszawa 1957, s. 85, 87, 90.

21 H. Kurkowska, S. Skorupka, Stylistyka polska. Zarys, Warszawa 1959, s. 202 . 
tensjonalność, kolokwializm i nieczytelny charakter, mogą wywoływać stylistyczny zgrzyt, a nawet zbliżać się do językowego kiczu.

W relacjach A. Kostyry zdecydowanie dominuja konstrukcje oryginalne, będacce wytworem zaskakującej wyobraźni samego autora oraz często przekraczające doświadczenie życiowe i językowe potencjalnego odbiorcy. Aby dobrze prześledzić wzajemne relacje komponentów porównania, należy przeanalizować zarówno comparandum (przedmiot, zjawisko porównywane), jak i comparatum (człon porównujący).

$Z$ uwagi na fakt, że mówione warianty wypowiedzi pochodzą $z$ relacji bokserskich, obiektami porównań są najczęściej sami pięściarze, rzadziej ich trenerzy, sędziowie walk czy zgromadzona w obiekcie sportowym publiczność. Sportowcy oraz ich zmagania na arenach ringowych poddawani sa subiektywnej ocenie dziennikarskiej. Bywa ona dwojaka: nobilitująca lub deprecjonująca. ${ }^{22}$ Obrazuja to najczęściej przymiotniki lub przysłówki będące w wypadku porównań A. Kostyry nieodłączną częscią comparandum:

Porusza się niezdarnie jak wóz drabiniasty z pijanym woźnica.

Zażarty jak bulterier jest Sidorenko.

Ręce ma szybkie jak złodziej kieszonkowy w warszawskim metrze.

Był gładki do odczytania jak otwarta księga.

Jest ostrożny jak bankier udzielający kredytu hipotecznego w czasach kryzysu.

Ocenę umiejętności bokserskich obrazują też czasowniki. Właściwe odczytanie zalet bądź wad możliwe jest jednak dopiero po uwzględnieniu znaczenia drugiego członu (comparatum). W wypadku porównań A. Kostyry $z$ reguly jest to ocena negatywna:

Rusza się jak wóz drabiniasty wypełniony po brzegi burakami cukrowymi.

Hipnotyzuje przeciwników jak wąż kurczaka. $Z$ bliska.

Już strzegł zwycięstwa jak rekin następnego posiłku.

Byrd okopał się w obronie jak Francuzi na linii Maginota.

Najbardziej charakterystyczną cechą porównań A. Kostyry jest stosowanie oryginalnego i zaskakującego obrazowania umiejętności bokserskich. Jest ono zestawiane $z$ różnorakimi dziedzinami współczesnego świata. Drugi z głównych członów porównania (comparatum) przynależy

22 O nobilitowaniu lub deprecjonowaniu sportowców oraz ich zachowań pisały m.in. Beata Grochala i Magdalena Makowska. Zob. B. Grochala, Sposoby nobilitowania $i$ deprecjonowania zawodników $i$ ich zachowan $w$ komentarzach sportowych [w:] R. Bizior, D. Suska (red.), Zjawisko nobilitacji i deprecjacji w tekście. Komunikacja, Częstochowa 2012, s. 31-47; przedruk [w:] M. Kita, I. Loewe (red.), Język w telewizji. Antologia, Katowice 2016, s. 239-254; M. Makowska, Medialne igrzyska. O jezzykowych i pozajezzykowych sposobach nobilitowania $i$ deprecjonowania sportowców na przykładzie relacji z Letnich Igrzysk Olimpijskich z Rio de Janeiro, „Tekst i Dyskurs” 2017, nr 10, s. 63-81. 
bowiem do różnych kręgów tematycznych. Są to m.in. konstrukcje porównawcze $z$ komponentami: przyrodniczym, cywilizacyjno-kulturowym, historycznym, antropologicznym, militarnym. Oto kilkanaście przykładów:

Nooo widzieliśmy w końcu w tej rundzie lewy prosty, rzadki jak deszcz na Saharze.

On miał takie szanse na przetrwanie tej serii ciosów jak śnieżny bałwan na pustyni.

Każdy człowiek musi się wyszumieć jak drzewo.

Darek chodzi jak tygrys po klatce.

Austin przed walka $z$ Kliczka był odważny jak kogut na własnej grzędzie.

Hipnotyzuje przeciwników jak wąż kurczaka. $Z$ bliska.

Ciosy spływaja po Sandersie jak woda po kaczce.

Byrd okopał się w obronie jak Francuzi na linii Maginota

Rzadko się myli Jackiewicz. Te jego ciosy sa jak bomby wyprowadzane laserem.

Morales ma wzrok mętny jak dwudniowe piwo.

Jego prowadzenie jest tak mało widoczne jak pierwszy zarost nastolatka.

Wałujew technicznie jest słaby jak szpadel ze złamanym członkiem.

Wyróżnione pola semantyczne, które występują w comparatum, można uszczegółowić w odniesieniu do świata natury i kultury. W wypadku przyrody autor $m$.in. sięga po rozwiązania $z$ komponentem klimatycznym, florystycznym, animalistycznym. W polu kulturowym tworzy porównania kulinarne, związane $z$ konkretnymi obiektami kultury materialnej, wreszcie przedmiotami codziennego użytku. W swoich porównaniach dziennikarz $z$ chęcia sięga też do świata ekonomii czy biznesu:

Wyglądał jak prezes jakiegoś banku centralnego, który obniżył oprocentowanie do zera.

Jest ostrożny jak bankier udzielający kredytu hipotecznego w czasach kryzysu.

Nierzadko też odwołuje się do postaci ze świata nauki, polityki i rozrywki. Moga to być zarówno konkretne osoby, jak i wykonywane przez nie zawody:

Byrdowi trener potrzebny jest mniej więcej tak jak Einsteinowi nauczyciel matematyki.

On ma tak wielkie doświadczenie, że w jego narożniku mógłby stać nawet Michael Jackson, a on walczyłby tak samo.

I znów czepia się Polaka jak minister Pitera posła za 5,40.

Pojedynki nudne jak nauczanie matematyki w liceum.

Ma ręce szybkie jak złodziej kieszonkowy w warszawskim metrze.

Pewnym wyznacznikiem stylu dziennikarskiego A. Kostyry jest stosowanie ironii. Znajduje ona odzwierciedlenie także w porównaniach komentatora walk bokserskich. Bardzo dobrze ten trudny do sklasyfikowania mechanizm językowo-semantyczny oddaja następujące komparacje:

Namęczył się jak aktorzy filmów pornograficznych przy dialogach.

Oni się lubia jak listonosz z bulterierem. 
Obydwie egzemplifikacje pozostają w zgodzie $z$ klasyczną definicją ironii. Autorzy Słownika terminów literackich traktuja ja jako:

właściwość stylu polegająca na sprzeczności między dosłownym znaczeniem wypowiedzi a jej znaczeniem właściwym, nie wyrażonym wprost, ale zamierzonym przez autora i zazwyczaj rozpoznawalnym dla odbiorcy. ${ }^{23}$

Jak słusznie zauważa K. Burska, w tego typu konstrukcjach dostrzeżenie sprzeczności między dosłownym znaczeniem komunikatu a pożądana przez dziennikarza interpretacja możliwe jest dopiero wtedy, gdy odbiorca zrozumie rzeczywistość pozajęzykową, do której odwołuje się autor komparacji. ${ }^{24}$

\section{FUNKCJA PORÓWNAŃ}

Konstrukcje porównawcze $\mathrm{w}$ mówionych wariantach wypowiedzi A. Kostyry pełnia kilka funkcji. Nie wszystkie $z$ nich ujawniaja się w jednakowym stopniu. Wydaje się, że najważniejsza jest funkcja komunikatywna. Komentarz sportowy jest bowiem pewna forma przekazu na linii nadawca (narrator transmisji) - odbiorca (telewidz). Poza obrazem telewizyjnym jego zadaniem jest więc ułatwienie oraz zrozumienie istoty widowiska sportowego (w tym wypadku zawodów bokserskich). Nie mniej istotna jest funkcja poznawcza. Porównania pozwalaja

wydobyć nowe odcienie znaczeniowe ze słów, pozwalają odnieść to, co nieznane, do tego, co znane, pozwalaja abstrakcję sprowadzić do konkretu, rzecz niewyobrażalna - do wyobrażalnej. ${ }^{25}$

Przez stosowanie oryginalnych porównań dziennikarz sportowy nie tylko wprowadza nowe elementy obrazowe, ale także pewne sugestie i stany emocjonalne, które towarzyszą mu w trakcie oglądania zawodów bokserskich. Dzięki nim komentarz sportowy nierzadko przyjmuje charakter emfatyczny. W ten sposób ujawnia się funkcja oceniająca (nobilitująca lub deprecjonująca sportowców) oraz przede wszystkim funkcja ekspresywna. Ta ostatnia jest jednym $z$ podstawowych wyznaczników mówionych wariantów środowiskowo-profesjonalnych (odmian dziennikarsko-sportowych). Poza stricte komunikacyjnym wymiarem komentarza, jak również jego funkcją poznawcza (dydaktyczna), istotna jego cechą jest także uatrakcyjnienie widowiska sportowego potencjalnemu odbiorcy

${ }^{23}$ M. Głowiński, T. Kostkiewiczowa, A. Okopień-Sławińska, J. Sławiński, op. cit., s. 221.

${ }^{24}$ K. Burska, op. cit., s. 51.

${ }^{25}$ M. Głowiński, A. Okopień-Sławińska, J. Sławiński, Zarys teorii literatury, Warszawa 1991, s. 111. 
(kibicowi). Stosowanie wyszukanych konstrukcji porównawczych, inkrustowanie wypowiedzi zaskakujacymi konotacjami ujawniaja w tym przekazie funkcję poetycka. Autoteliczność komentarza, kreatywność oraz oryginalność jego twórcy wysuwa wówczas formę językowa na pierwszy plan. Bezpośrednio $z$ funkcją estetyczną koresponduje funkcja ludyczna. Porównania mogą bowiem służyć rozbawieniu odbiorcy, a co za tym idzie - zyskaniu jego sympatii. ${ }^{26}$ Każdorazowo dobór środków językowych oraz ich bogaty repertuar może być jednak poddawany zróżnicowanej ocenie.

\section{PRÓBA OCENY}

W mówionych wariantach wypowiedzi A. Kostyry zdecydowanie przeważaja porównania wysoce zindywidualizowane. Bardzo rzadko występują komparatywa utarte i potoczne. Można więc powiedzieć, że dziennikarz ten wykazuje się znaczną inwencją twórczą i kreatywnością językowa. Jego język jest niezwykle barwny i nieskonwencjonalizowany. Biorąc pod uwagę repertuar środków językowych, w opinii piszącego te słowa, obok struktur udanych trafiaja się i takie, które budzą wątpliwości. Ich szczegółowa ocena wymagałaby prześledzenia tertium comparationis oraz relacji podobieństwa członu porównywanego $z$ porównujacym. Przykładowo, o ile porównanie solidny jak kościelne drzwi, odsyłające odbiorcę do rzeczywistości pozajęzykowej, wydaje się dość trafne i czytelne, o tyle określenie boksera mianem wolnego jak ketchup jest już dyskusyjne. Nadmiar struktur porównawczych oraz nie zawsze ich trafność sprawia, że komentator walk bokserskich przekracza czasami granice świeżości stylistycznej. Jak zauważa Jan Miodek,

określenie owej granicy jest bardzo trudne. Tylko umiejętność zobiektyzowania przeżywanych emocji i doświadczenie stylistyczne moga uchronić przed jej przekroczeniem. ${ }^{27}$

Budowanie komparatywów na podstawie bardzo odległych skojarzeń $z$ jednej strony może zatem świadczyć o bogatej wyobraźni autora, $z$ drugiej zaś dowodzić braku wyczucia językowego.

$Z$ pewnościa A. Kostyra jako dziennikarz nie tylko telewizyjny, ale również prasowy i internetowy jest świadomy specyfiki swojego oryginalnego języka oraz nadmiaru konstrukcji porównawczych. Być może w ten sposób chce pozostać nietuzinkowy i rozpoznawalny. Atrakcyjny, nieszablonowy przekaz $z$ reguły gromadzi bowiem większą widownię,

26 K. Burska, op. cit., s. 57.

27 J. Miodek, O języku do kamery, Rzeszów 1992, s. 94; M. Koper, 2003, „Poezja futbolu”. Kilka uwag o języku sprawozdawców sportowych [w:] W. Książek-Bryłowa, H. Duda (red.), Język polski. Współczesność. Historia, Lublin, s. 51-62. 
sama zaś dyskusja wokół tej specyficznej narracji wywołuje pewne emocje. Wszystkie konstrukcje porównawcze wpisuja się w poetykę odmiany dziennikarsko-sportowej. W wypadku języka A. Kostyry być może sa nawet przejaskrawieniem tego, co się obecnie dzieje w profesjolekcie dziennikarskim. W opinii piszącego te słowa nadmiar tropów stylistycznych, emfatyczny charakter narracji może wreszcie prowadzić do językowego ekshibicjonizmu. Oceniając w sposób subiektywny Paganiniego sportowego mikrofonu (tak nazywaja dziennikarza zwolennicy jego relacji), można odnieść wrażenie, że albo jego skrzypce nie zawsze dobrze stroja, albo są słabej marki, albo też sam wirtuoz dokonuje zbyt wielu eksperymentów w trakcie koncertu. Niewatpliwie „sportowy altowiolista” przykuwa swoim językiem uwagę odbiorców, czego dowodem jest także ten artykuł. Ekstrawagancja językowa, która przesłania samo widowisko bokserskie, może w istocie nie ułatwiać, ale komplikować jego odbiór.

\section{PODSUMOWANIE}

Barwny język A. Kostyry wpisuje się w relacje innych dziennikarzy sportowych, którzy często posługują się leksyką emocjonalną, zindywidualizowana i nasaczona tropami stylistycznymi. Jak pokazują badania innych odmian językowych, nie jest to wyłącznie specyfika relacji sportowej. Przykładem może być współczesny język religijny, w którym występujące wysoko zindywidualizowane komparatywa bardzo często przekraczaja potoczne doświadczenie życiowe i językowe odbiorcy. ${ }^{28}$ Wszystkie te cechy znajduja odzwierciedlenie w relacjach A. Kostyry, który zapewne w sposób świadomy uznał porównanie za ulubiony trop stylistyczny oraz wyznacznik swoich wypowiedzi. Komparacje oraz ich zaskakujący charakter polega na wykorzystywaniu całego wachlarza skojarzeń zwiazanych $z$ natura, kultura, religia i społeczeństwem. Jak zauważa K. Burska, wiele $z$ nich to konstrukcje absurdalne, sięgające głębokich pokładów ludzkiej wyobraźni. Uwidacznia się w nich zarówno sięganie po zakorzenione w języku i kulturze stereotypy, jak też utrwalone wzorce społeczne. Wszystkie struktury porównawcze maja za zadanie uatrakcyjnić i ubarwić przebieg sportowego widowiska. ${ }^{29}$

Autor niniejszego artykułu nie rości sobie pretensji do pełnego omówienia przedstawionej problematyki zarówno w odniesieniu do konstrukcji porównawczych w języku mówionym A. Kostyry, jak i w ogólnym

28 M. Nowak, Porównania we współczesnym języku religijnym (na podstawie tekstów nieartystycznych), „Poznańskie Spotkania Językoznawcze” 2004, t. XIII, s. 101.

${ }^{29} \mathrm{~K}$. Burska, $Z$ Czuba i na żywo - językowe sposoby kształtowania relacji sportowych na żywo na portalu internetowym www.zczuba.pl [w:] M. Jarosz, P. Drzewiecki, P. Płatek (red.), Sport w mediach, Warszawa 2013, s. 59. 
zastosowaniu tej figury stylistycznej w dziennikarstwie sportowym. Złożony charakter tych konstrukcji, ich wielofunkcyjność, niejednolitość formalna i znaczeniowa oraz różnorodne zastosowanie $z$ pewnością będa jeszcze niejednokrotnie przedmiotem badań i szczegółowych analiz. Szkic, w którym dokonano pobieżnie semantycznej, strukturalno-gramatycznej i funkcjonalnej analizy dziennikarskich komparatywów wymaga pogłębionych badań m.in. na podstawie ustaleń współczesnej kognitywistyki czy retoryki. Niezbędna wydaje się również dogłębna analiza wszystkich odmian języka sportowego, uwzględniająca profesjolekt wielu dziennikarzy sportowych.

\section{Bibliografia}

K. Burska, 2013, Z Czuba i na żywo - językowe sposoby kształtowania relacji sportowych na żywo na portalu internetowym www.zczuba.pl [w:] M. Jarosz, P. Drzewiecki, P. Płatek (red.), Sport w mediach, Warszawa, s. 46-72.

K. Burska, 2016, Porównanie jako przejaw językowej kreatywności dziennikarzy sportowych (na materiale $z$ wortalu iGol.pl) [w:] A. Czapla, M. Koper (red.), Język $i$ sport, Lublin, s. 41-59.

D. Buttler, 1977, Porównania w twórczości Żeromskiego [w:] Z. Goliński (red.), Stefan Żeromski. W pięćdziesiąta rocznice śmierci. Studia i szkice, Warszawa, s. $258-276$.

K. Czemplik, 2014, Czasami zaskakujacy, czasami zabawny, ale jakże oryginalny język relacji sportowych Zimowych Igrzysk Olimpijskich Soczi 2014 [w:] K. Burska, B. Cieśla (red.), Kreatywność językowa w przestrzeni medialnej, Łódź, s. 49-58.

Česka přirownání [w:] Slownik české frazeologie a idiomatiky. Přirownání, Praha 1983.

Z. Gałecki, 2012, Slavek $i$ Slavko - nazwy maskotek Mistrzostw Europy $w$ Piłce Nożnej 2012, „Roczniki Humanistyczne” t. LX, z. 6, s. 87-95.

Z. Gałecki, 2014, „Czyste szaleństwo”-współczesna piosenka okolicznościowa. Liber i zespół InoRos [w:] J. Kuć, K. Wojtczuk (red.), Język a muzyka. Ujęcie filologiczne i muzykologiczne, Siedlce, s. 23-29.

M. Głowiński, T. Kostkiewiczowa, A. Okopień-Sławińska, J. Sławiński, 2002, Słownik terminów literackich, Wrocław.

M. Głowiński, A. Okopień-Sławińska, J. Sławiński, 1991, Zarys teorii literatury, Warszawa.

B. Grochala, 2012, Sposoby nobilitowania i deprecjonowania zawodników i ich zachowań w komentarzach sportowych [w:] R. Bizior, D. Suska (red.), Zjawisko nobilitacji i deprecjacji w tekście. Komunikacja, Częstochowa, s. 31-47; przedruk [w:] M. Kita, I. Loewe (red.), Język w telewizji. Antologia, Katowice 2016, s. 239-254.

B. Grochala, 2015, Telewizyjna transmisja sportowa jako kolekcja gatunków [w:] D. Ostaszewska, J. Przyklenk (red.), Gatunki mowy i ich ewolucja, t. 5: Gatunek a granice, Katowice, s. 347-355.

B. Grochala, 2016, Telewizyjna transmisja sportowa w ujęciu genologii lingwistycznej na materiale meczów piłki nożnej, Łódź. 
B. Grochala, 2016, Kicz jako sposób wyrażania emocji (metaforyka radiowych relacji sportowych) [w:] B. Kudra, E. Szkudlarek-Śmiechowicz (red.), Kicz w języku i komunikacji, Łódź, s. 335-342.

B. Jarosz, 2012, Sposoby wartościowania w wypowiedziach komentatorów siatkarskich [w:] M. Karwatowska, A. Siwiec (red.), Wartości i wartościowanie $w$ badaniach nad językiem, Chełm, s. 133-144.

M. Joka, 2001-2002, Indywidualne warianty comparatora $w$ twórczości Jana Parandowskiego, „Roczniki Humanistyczne” t. XLIX-L, s. 145-158.

Z. Klemensiewicz, 1957, Zarys składni polskiej, Warszawa.

M. Koper, 2003, „Poezja futbolu”. Kilka uwag o języku sprawozdawców sportowych [w:] W. Książek-Bryłowa, H. Duda (red.), Język polski. Współczesność. Historia, Lublin, s. 51-62.

M. Koper, 2009, Emocje w języku sprawozdawców sportowych [w:] K. Wojtczuk, V. Machnicka (red.), Rejestr emocjonalny języka, Siedlce, s. 67-76.

M. Koper, 2012, Peryfrazy w języku komentatorów sportowych, „Roczniki Humanistyczne" t. 60, z. 6, s. 113-112; przedruk [w:] M. Kita, I. Loewe (red.), Język $w$ telewizji. Antologia, Katowice 2016, s. 217-226.

M. Koper, 2016, Język sportu-problematyka badawcza [w:] A. Czapla, M. Koper (red.), Język i sport, Lublin, s. 13-40.

M. Koper, 2019, Polska dawaj! O języku piłkarskiego hasła oraz jego bliższych $i$ dalszych konotacjach, „Poradnik Językowy” z. 1, s. 95-105.

A. Kostyra, 2017, Walki stulecia. Bohaterowie wielkiego boksu, Kraków.

A. Kudra, 2003, Porównanie w poezji Tadeusza Różewicza (lata 1945-1950), „Acta Universitatis Lodziensis. Folia Litteraria Polonica” 6, s. 313-321.

H. Kurkowska, S. Skorupka, 1959, Stylistyka polska. Zarys, Warszawa.

Z. Leszczyński, 1994, Doświadczenie tekstów sakralnych odbite $w$ obiegowych porównaniach, „Łódzkie Studia Teologiczne” z. 3, s. 151-163.

I. Loewe, 2014, Sport $w$ mediasferze z perspektywy lingwisty, „Postscriptum Polonistyczne" nr 2 (14), s. 71-91.

I. Loewe, 2020, Sport, medium, dyskurs telewizyjny. Mediolingwistyczne rozważania o wpływie, „Zeszyty Prasoznawcze” t. 63, nr 2 (242), s. 31-46.

M. Majewska, 2004, Porównania w „Urodzie życia” Stefana Żeromskiego (materiał badawczy z objaśnieniami), „Prace Filologiczne” t. XLIX, s. 317-346.

M. Makowska, 2017, Medialne igrzyska. O językowych i pozajęzykowych sposobach nobilitowania i deprecjonowania sportowców na przykładzie relacji z Letnich Igrzysk Olimpijskich z Rio de Janeiro, „Tekst i Dyskurs” nr 10, s. 63-81.

B. Mikołajczak, 1976, Porównania w „Faraonie” Bolesława Prusa, „Studia Polonistyczne" t. III, s. 105-114.

J. Miodek, 1992, O języku do kamery, Rzeszów.

E. Młynarczyk, 1994, Porównanie w powieści W. Myśliwskiego „Kamień na kamieniu”, „Rocznik Naukowo-Dydaktyczny WSP w Krakowie. Prace Językoznawcze" t. VIII, s. 149-155.

Z. Mokranowska, 1982, Porównania z „Ogniem i mieczem” Henryka Sienkiewicza [w:] H. Bursztyńska (red.), Henryk Sienkiewicz: tradycja-kreacja-styl, Katowice, s. 114-130.

M. Nowak, 2004, Porównania we współczesnym języku religijnym (na podstawie tekstów nieartystycznych), „Poznańskie Spotkania Językoznawcze” t. XIII, s. 91-101. 
M. Pietrzak, 2001, Rośliny w porównaniach występujacych w „Trylogii” Henryka Sienkiewicza [w:] A. Dabrowska (red.), Język a kultura, t. 16: Świat roślin w języku i kulturze, Wrocław, s. 169-179.

J. Podracki, 1978, Wpływ słownictwa sportowego na inne odmiany polszczyzny, „Kultura Fizyczna” nr 6, s. 265-269.

K. Siekierska, 1981, Porównania w „Wojnie chocimskiej” Wacława Potockiego i w „Pamiętnikach” Jana Chryzostoma Paska, „Polonica” t. VII, s. 233-254.

U. Sokólska, 2001/2002, Porównania charakteryzujace ludzi i zachowania ludzkie $w$ reportażach $M$. Wańkowicza, „Roczniki Humanistyczne” z. 6, s. 391-402.

M. Zarębina, 1990, Porównania w „Anielce” i „Placówce” Bolesława Prusa, „Polonica" t. XV, s. 131-144.

L. Zieliński, 2002, Wpływ słownictwa sportowego na język polityki [w:] G. Szpila (red.), Język a komunikacja 4. Zbiór referatów z konferencji pt. Język trzeciego tysiąclecia II (Kraków, 28 lutego-2 marca 2002), t. I: Nowe oblicza komunikacji we współczesnej polszczyźnie, Kraków, s. 261-270.

\section{Knockout is unavoidable here like wrinkles in your sixties. A few comments on the comparative formations in utterances by Andrzej Kostyra, a sports journalist}

\section{Summary}

In this paper, an analysis of selected issues related to comparative formations occurring in utterances by Andrzej Kostyra, a sports journalist, are presented. Simple and then complex comparatives have been analysed. As regards the semantic analysis, semantic fields of comparative components have been presented and their functions have been identified and assessed subjectively.

Keywords: comparison - language of sport - commentary - relation - utterances - journalist.

Trans. Monika Czarnecka 
(Uniwersytet Warszawski, e-mail: m.wojtynska-no@uw.edu.pl)

ORCID: 0000-0002-4450-7802

\section{ZAPOŻYCZENIA W SEOWNICTWIE WYŚCIGÓW KONNYCH \\ W DWUDZIESTOLECIU MIĘDZYWOJENNYM (NA PODSTAWIE CZASOPISMA „JEŹDZIEC I HODOWCA")}

Wyścigi konne w Polsce mają blisko 180-letnią tradycję, której początek przypada na 1841 rok, kiedy to powstało w Warszawie Towarzystwo Wyścigów Konnych, a która trwa do dziś. Warto wspomnieć, że najważniejsza gonitwę, czyli Derby, rozegrano po raz pierwszy na warszawskim torze w 1870 roku - wygrał ją koń pełnej krwi angielskiej Mabil (Confortes - Grizetta) własności hrabiego A. Potockiego. ${ }^{1} \mathrm{~W}$ okresie międzywojennym wyścigi z krótszymi przerwami odbywały się nie tylko w Warszawie, ale i na wielu torach prowincjonalnych. Druga wojna światowa stanowiła okres przerwy w życiu wyścigowym. Większość polskich koni pełnej krwi angielskiej została zrabowana przez niemieckiego okupanta, a konie czystej krwi arabskiej zostały badź bezprawnie zabrane, bądź zastrzelone przez Armię Czerwoną. Konie, które cudem udało się ocalić, zostały ewakuowane m.in. do Szwajcarii. Po wyzwoleniu najlepsze konie czystej krwi arabskiej zostały zrabowane $z$ kolei przez wojska amerykańskie i wywiezione do USA, gdzie dały zaczatek cennych linii hodowlanych. W kraju ostały się jedynie resztki przedwojennej hodowli. Tuż po wojnie, w roku 1945 , otwarto trzy tory wyścigowe: w stolicy, we Wrocławiu i w Sopocie. ${ }^{2}$ Funkcjonują one do dziś.

W niniejszym artykule skoncentrowałam się na wybranym okresie historii wyścigów konnych w Polsce, a mianowicie na 20-leciu międzywojennym. Był to czas bardzo dynamicznego rozwoju jeździectwa w niepodległej Polsce. Dla słownictwa wyścigów konnych znamienne jest to, że sport ten opierał się na wzorach brytyjskich i francuskich zarówno pod względem instytucjonalnym, jak i hodowlanym (z tych krajów pochodził

$1 \mathrm{~W}$ nawiasach podaje się pochodzenie konia, czyli imię ojca i matki.

2 Historię wyścigów konnych w Polsce opisał W. Pruski. Zob. W. Pruski, Dzieje wyścigów i hodowli koni pełnej krwi angielskiej w Polsce. Królestwo Polskie 1815-1918, Warszawa 1970; W. Pruski, Wyścigi i hodowla koni pełnej krwi oraz czystej krwi arabskiej w Polsce w latach 1918-1939, Wrocław-WarszawaKraków-Gdańsk 1980. 
materiał zarodowy koni pełnej krwi angielskiej). Dlatego też jako historyka języka szczególnie zainteresowało mnie zagadnienie genezy wytypowanego zasobu leksykalnego rozpatrywanego $z$ perspektywy wpływu czynników pozajęzykowych związanych $z$ nową ówcześnie konkurencją sportowa.

Podstawa materiałową analizy mieszczącej się w nurcie strukturalizmu uczyniłam próbkę słownictwa w postaci rzeczowników wyekscerpowanych $z$ losowo wybranych 60 numerów tygodnika „Jeździec i Hodowca". Publikacja ukazywała się w latach 1922-1939, była organem Polskiego Związku Hodowców Koni i jednocześnie pierwszym autonomicznym czasopismem, które w całości poświęcone zostało tematyce związanej z hodowlą i użytkowaniem koni w Polsce. Jak patetycznie nadmieniła Redakcja w pierwszym numerze pisma,

Rozpoczynając wydawnictwo niniejsze, czynimy to w przekonaniu, że sport polski i hodowla znalazły się już w tym stadjum tworzenia, które wymaga wszechstronnej wymiany myśli, oświetleń krytycznych, ustanowienia kierunku i celu pracy i pośrednictwo to musi spełnić organ specjalny, do którego stworzenia przystępujemy $z$ całym wysiłkiem energji. Wprawdzie prasa polska, doskonale rozumiejąc rolę sportu końskiego, nie szczędziła nigdy miejsca wszystkim objawom jego życia, obowiazkiem jednak jest naszym ujęcia dziś ciężaru gościnnej prasie, przed którą leży cały niezmierzony obszar życia państwowego.

(...) Życiu, tego najszlachetniejszego stworzenia, tego najwierniejszego towarzysza wojennej doli i niedoli polskiej, dziełom jego i tryumfom poświęcimy pismo nasze; żołnierski towarzysz z pod Sammossiery, Krechowiec, uczestnik bohaterskich dni sierpniowych godzien jest nietylko nielicznych uwielbień i rymu. Należy mu się kronika żmudna i pilna, jakby cierpliwy rejestr gospodarski, który będzie zbiorowym dokumentem doświadczeń, aby mógł z nich korzystać każdy, kto rozumie rolę konia $\mathrm{w}$ gospodarstwie narodowem. Hodowla polskiego konia - jest jednem $z$ narodowych przykazań. Świetność jego dziejow i co ważniejsze, świetność jego przyszłości, będzie troską główną wszystkich słów, które na tych ukażą się stronnicach. ${ }^{3}$

Z punktu widzenia historii języka „Jeździec i Hodowca” jest cennym dokumentem, gdyż w każdym numerze magazynu odnaleźć można skrupulatne relacje $z$ wyścigów konnych rozgrywanych zarówno na torach krajowych, jak i zagranicznych. Pomimo zawieruchy wojennej do naszych czasów zachowały się bardzo liczne zeszyty czasopisma, co umożliwia dosyć dokładne prześledzenie rozwoju wybranego przeze mnie zasobu leksykalnego.

Przystępując do studium leksyki, trzeba wyraźnie zaznaczyć, że jego przedmiotem nie jest całe słownictwo wyścigów konnych $z$ dwóch dekad międzywojnia, lecz jedynie ta jego niewielka część, która znalazła się na łamach losowo wybranych numerów czasopisma "Jeździec i Hodowca”. Niniejsza analiza nie daje zatem obrazu całości zasobu leksykalnego związanego $z$ wyścigami, lecz jedynie go zarysowuje i stanowi próbę wskazania ogólnych kierunków jego rozwoju.

3 „Jeździec i Hodowca” 1922, nr 1, s. 2. 
Zacznijmy od przywołania danych statystycznych odnoszacych się do wyekscerpowanego słownictwa. Na omawiany zbiór złożyło się 241 rzeczowników (45 $z$ nich to zestawienia), $z$ czego 159 to zapożyczenia. Jak widać, już na wstępie można stwierdzić, że cechą charakterystyczną badanego zbioru jest przewaga wyrazów obcych, które stanowią $66 \%$ badanego zasobu leksykalnego. ${ }^{4}$

Tabela nr 1. Klasyfikacja genetyczna wyekscerpowanych rzeczowników ${ }^{5}$

\begin{tabular}{|l|c|c|}
\hline \multicolumn{1}{|c|}{ Geneza słownictwa } & Liczba leksemów & $\begin{array}{c}\text { Udział } \\
\text { [\%] }\end{array}$ \\
\hline angielski & 106 & 44,0 \\
\hline rodzime & 82 & 34,0 \\
\hline francuski & 22 & 9,1 \\
\hline niemiecki & 14 & 5,8 \\
\hline łaciński & 10 & 4,1 \\
\hline rosyjski & 2 & 0,8 \\
\hline turecki & 2 & 0,8 \\
\hline czeski & 1 & 0,4 \\
\hline grecki & 1 & 0,4 \\
\hline ukraiński & 1 & 0,4 \\
\hline Razem & $\mathbf{2 4 1}$ & $\mathbf{1 0 0 , 0}$ \\
\hline
\end{tabular}

Duży udział wyrazów obcych należy tłumaczyć tym, że rozpatrywana przeze mnie dyscyplina sportowa była w Polsce całkiem nowa, co przełożyło się na bardzo duże potrzeby nominacyjne w jej zakresie. Wprowadzenie wyścigów konnych do życia sportowego na ziemiach polskich wymagało przejęcia w stosunkowo krótkim czasie bardzo wielu desygnatów wraz $z$ ich ustalonymi obcojęzycznymi nazwami. $Z$ punktu widzenia językoznawstwa skutkowało to tym, że w zakresie przedmiotu zapożyczenia napływały przede wszystkim pożyczki formalnosemantyczne,

4 Co koresponduje z wynikami badań J. Ożdżyńskiego, zob. J. Ożdżyński, Polskie współczesne słownictwo sportowe, Wrocław-Warszawa-Kraków 1970, s. 13.

${ }^{5}$ Klasyfikację genetyczna przeprowadziłam na podstawie informacji etymologicznej zawartej w Uniwersalnym słowniku języka polskiego pod red. nauk. S. Dubisza, Warszawa 2008. W wypadku gdy słownik podaje więcej niż jeden język źródłowy pożyczki, przyjmuję tę etymologię, która wymieniona została na pierwszym miejscu. 
ale także kalki strukturalne i frazeologiczne. ${ }^{6}$ Uwidacznia się zwłaszcza spora liczba zestawień wzorowanych na angielskim słownictwie wyścigowym, co zilustrowano w tabeli $\mathrm{nr} 2$.

Wśród języków źródłowych wyraźnie dominowały anglicyzmy, co trzeba poczytać za najważniejszy przejaw wpływu czynników pozajęzykowych na badany zasób leksykalny - wszak ojczyzną wyścigów konnych jest Wielka Brytania, skąd też sport ten przywędrował do naszego kraju. Na drugim i trzecim miejscu usytuowały się galicyzmy i germanizmy, co stanowi odzwierciedlenie wzmożonych kontaktów $z$ Francją i z Niemcami jako tymi krajami, w których sport wyścigowy funkcjonował o wiele wcześniej niż w Polsce i gdzie w drugiej kolejności szukano gotowych rozwiązań ułatwiających przeszczepienie sportu wyścigowego oraz skąd nabywano dodatkowy materiał zarodowy.

Należy zauważyć, że obecność wielu latynizmów w publikacjach angielskojęzycznych $z$ drugiej połowy XIX w. i z początku XX w., poświęconych brytyjskim wyścigom konnym, nasuwa przypuszczenie, że w niektórych wypadkach zaszedł proces powtórnego ich zapożyczenia, ale w nowych znaczeniach, zwiazanych ze sportem konnym. Pożyczki te przywędrowały do systemu leksykalnego polszczyzny powtórnie, tym razem bezpośrednio $z$ języka angielskiego. Wymienić tu można takie leksemy jak np.: akcja, forma, klasa, kondycja, kolory, okulary. Nie można jednakże wykluczyć, że podczas kształtowania się słownictwa wyścigów konnych dokonał się na gruncie polszczyzny proces neosemantyzacji (lub - przy innym ujęciu - homonimizacji) starych pożyczek łacińskich, czego przyczyna był wzmożony wpływ języka angielskiego.

Trzeba stwierdzić, że w zakresie adaptacji przejmowanych jednostek leksykalnych do systemu językowego polszczyzny bardzo wyraźnie uwidacznia się łatwość i szybkość przyswajania gramatycznego wyrazów zapożyczonych. W rozpatrywanym materiale leksykalnym bardzo trudno jest ustalić występowanie cytatów, gdyż ogromna większość rzeczowników obcych została wyposażona w polskie końcówki fleksyjne. To, że $\mathrm{w}$ wybranych numerach czasopisma pojawiła się forma oryginalna, którą moglibyśmy uznać za wtręt, nie znaczy, że w pozostałych numerach nie podlegała ona włączeniu do polskiej fleksji. Dlatego też w niniejszej analizie nie zdecydowałam się na wyodrębnienie grupy cytatów - próbę taką można by podjać na podstawie rozpatrzenia zawartości wszystkich zachowanych numerów czasopisma „Jeździec i Hodowca”. ${ }^{7}$ Pod względem

6 Typologię zapożyczeń przyjęłam za H. Karaś, która wyodrębniła pożyczki formalnosemantyczne oraz kalki leksykalne, dzielące się na kalki leksykalne strukturalne (wyrazowe i frazeologiczne) oraz semantyczne. Zob. H. Karaś, Rusycyzmy słownikowe w polszczyźnie okresu zaborów, Warszawa 1996, s. 53.

7 Należy w tym miejscu przywołać także konstatację B. Nowowiejskiego, który słusznie zwrócił uwagę na trudności w ustalaniu wtrętów i na brak możliwości wytyczenia ostrej granicy pomiędzy cytatem a zapożyczeniem. Zob. 
graficznym uwagę zwraca duża wariantywność w sposobach dodawania końcówek - najczęściej stosowany był zapis $z$ apostrofem, choć te same formy pojawiały się i $z$ tym znakiem, i bez niego, co mogło być spowodowane także brakiem w pełni ustabilizowanych przepisów ortograficznych w tym zakresie (np.: miler'a, champion-fleyery, crack'ów, derby-cracków, outsider'ami, sprinter'em, stallion'ów). O dynamicznym tempie ekspansji omawianych pożyczek świadczy to, że bardzo szybko stawały się podstawami słowotwórczymi, od których derywowano na dużą skalę chociażby feminatywa (np.: leaderka, steyerka, steeplerka, oaksistka).

Co do sposobu zapożyczania, trzeba wskazać, że przejmowanie nowych jednostek leksykalnych dokonywało się głównie na drodze wzrokowej. Świadczy o tym zapis graficzny pożyczek zachowujacy w bardzo wielu wypadkach postać oryginalną. Jednocześnie trzeba dodać, że w wyekscerpowanym materiale możemy zaobserwować dużą wariantywność form pisowniowych, co $z$ jednej strony dowodzi intensywności procesu adaptacji badanych elementów leksykalnych do polskiej grafii, $z$ drugiej zaś - nieustabilizowana forma świadczy o tym, że dopiero w ostatnim okresie wzbogaciły one system leksykalny polszczyzny. Przewaga kanału wzrokowego jest wynikiem przemian cywilizacyjnych, które dokonały się w drugiej połowie XIX w. i na początku XX stulecia, a mianowicie zwiększenia szybkości wymiany informacji i ich stopnia rozpowszechnienia, co dokonywało się głównie za pośrednictwem prasy. W 20-leciu międzywojennym nie bez znaczenia pozostawała otwartość naszego kraju na wymianę kulturalną i łatwość dostępu zarówno do międzynarodowej prasy, jak i do obcojęzycznych publikacji specjalistycznych $z$ różnych dziedzin wiedzy i życia społeczno-kulturalnego. W okresie II Rzeczypospolitej dobrze sytuowani hodowcy koni dość ostro rywalizowali między sobą pod względem jakości posiadanych koni wyścigowych, stąd też zakup zwierzęcia na rynku brytyjskim czy francuskim był poprzedzony skrupulatnym rozpatrywaniem rodowodów wyścigowców i bacznym śledzeniem osiagnięć przedstawicieli danych linii hodowlanych na torach zagranicznych.

Przejdźmy w tym miejscu do zagadnienia chronologii zapożyczeń, które poddałam analizie, opierając się na wybranych słownikach języka polskiego. ${ }^{8}$ Rysuje się ono dosyć interesująco, a ilustruja je dane przedstawione w poniższej tabeli.

B. Nowowiejski, Zapożyczenia leksykalne z języka niemieckiego w polszczyźnie XIX wieku (na materiale czasopism), Białystok 1996.

8 W. Doroszewski (red.), Słownik jezyka polskiego, t. 1-11, Warszawa 1958-1969 (dalej SJPDor); S.B. Linde, Słownik języka polskiego, Warszawa 1807-1815, t. 1-6 (dalej SL); Słownik języka polskiego, wyd. staraniem M. Orgelbranda, t. 1-2, Wilno 1861 (dalej SWil); J. Karłowicz, A. Kryński, W. Niedźwiedzki (red.), Słownik języka polskiego, t. 1-8, Warszawa 1900-1927 (dalej SW); S. Dubisz (red. nauk.), Uniwersalny słownik języka polskiego, Warszawa 2008 (dalej USJP). 


\begin{tabular}{|c|c|c|c|c|c|c|}
\hline 宽 ๖ & $\overbrace{0}^{+}$ & $\stackrel{\sim}{\stackrel{\sim}{\sim}}$ & $\hat{\circ}$ & $\stackrel{\infty}{\stackrel{\infty}{\sim}}$ & $\begin{array}{l}a \\
\stackrel{\rho}{q}\end{array}$ & $\begin{array}{l}0 \\
0 \\
8 \\
0 \\
-1\end{array}$ \\
\hline 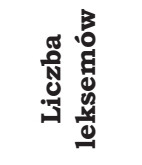 & $\stackrel{\theta}{N}$ & $\overrightarrow{\mathrm{N}}$ & 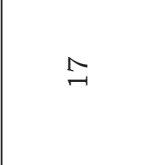 & ৯ & $\stackrel{\Omega}{\Omega}$ & ஜి \\
\hline 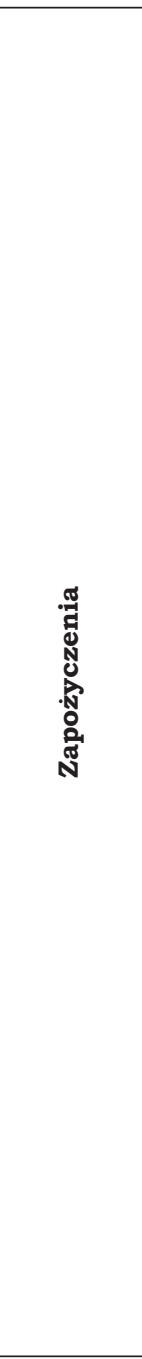 & 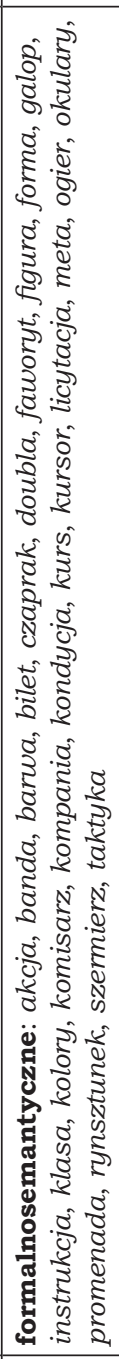 & 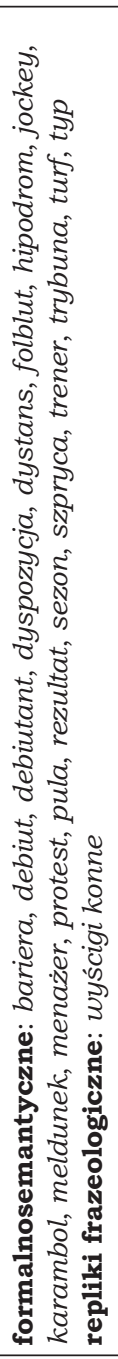 & 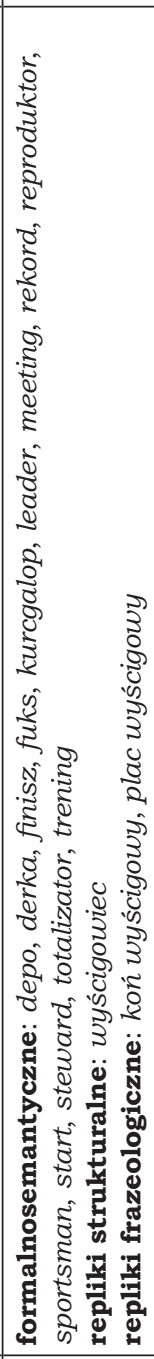 & 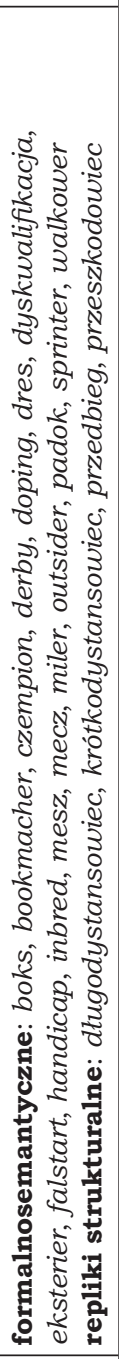 & 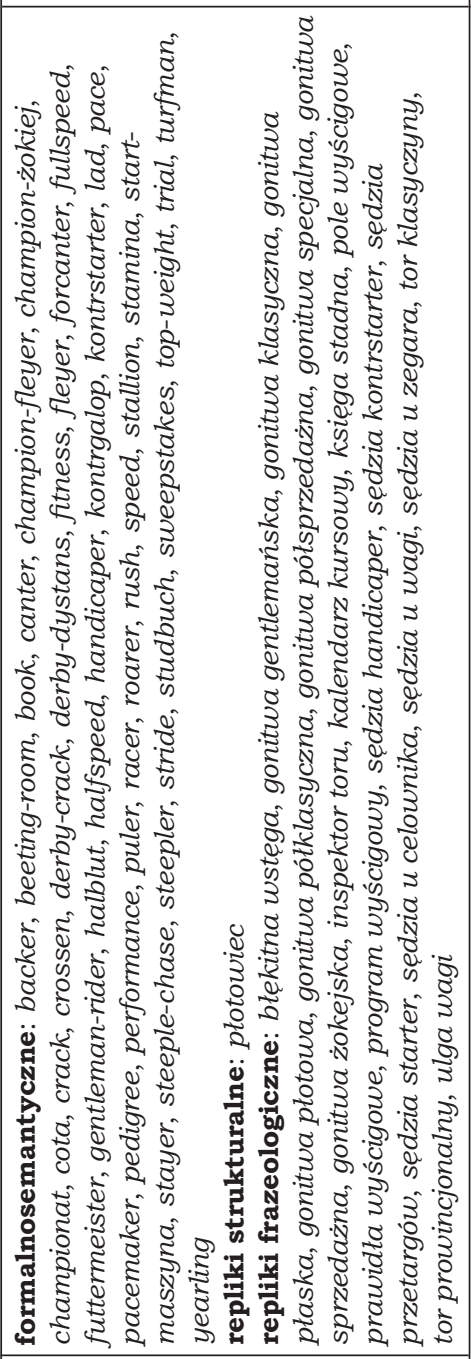 & \\
\hline 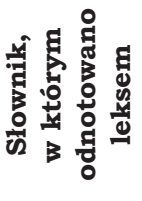 & $\overrightarrow{\sigma_{2}}$ & 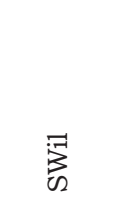 & $\sqrt{2}$ & & 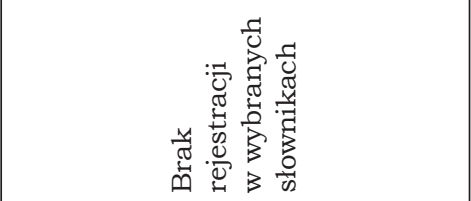 & 量 \\
\hline
\end{tabular}


Stan rejestracji rozpatrywanego przeze mnie zbioru w wybranych źródłach leksykograficznych wskazuje, że w słowniku Lindego odnotowanych zostało $16 \%$ wyrazów zapożyczonych, które weszły w skład badanego przeze mnie słownictwa. Trzeba nadmienić, że $z$ oczywistych względów - SL obejmował słownictwo do początków XIX w., czyli do pół wieku przed zorganizowaniem wyścigów konnych w Warszawie - została zarejestrowana semantyka funkcjonujacca w ogólnej odmianie języka polskiego, a nie specjalistyczna, zwiazana ze sportem hippicznym. Wszystkie odnotowane w SL rzeczowniki, poza leksemami bilet, czaprak, licytacja, meta, ogier, na polu słownictwa wyścigowego uległy neosemantyzacji. Należy jednak uznać, że jest to najstarsza warstwa leksyki zapożyczonej, stanowiąca podstawę, wokół której narastało i kształtowało się słownictwo zwiazane $z$ nową dziedzina sportu. Ten elementarny zasób reprezentowany jest przez 10 latynizmów, 6 galicyzmów, 6 germanizmów, dwa orientalizmy oraz przez jeden anglicyzm i jeden bohemizm.

W Słowniku wileńskim w stosunku do SL odnotowano 21 nowych pożyczek (9 galicyzmów, 5 anglicyzmów, 4 germanizmy, 2 rusycyzmy i 1 grecyzm), z których leksykografowie już dla 7 jednostek leksykalnych zaproponowali znaczenia, w których funkcjonowały one w słownictwie sportowym (dystans, folblut, hipodrom, pula, rezultat, trener, wyścigi konne).

Największa zmiana pod względem i języków źródłowych, i kwalifikacji pożyczek $z$ punktu widzenia odmian komunikacyjnych polszczyzny widoczna jest w SW (11 anglicyzmów, 3 galicyzmy, 2 germanizmy i 1 ukrainizm) oraz w SJPDor (20 anglicyzmów i 2 galicyzmy), w których słownictwo o znaczeniach odmiennych niż zwiazane ze sportem pozostaje w mniejszości (w SW to: depo, fuks, meeting, w SJPDor to: dres). Trzeba tu zaznaczyć, że choć egzemplifikacje podawane w definicjach słownikowych odnoszą się głównie do czynności wykonywanych przez ludzi, to ich semantyka jest znacznie szersza, np. mecz 'spotkanie sportowe' można odnieść do każdej dyscypliny sportu, bez różnicy, czy rywalizują w jej obrębie tylko ludzie, czy także zwierzęta. Warto także dodać, że wraz $\mathrm{z}$ rozwojem leksykografii wzbogaca się i doskonali system kwalifikatorów, czego świadectwem jest to, że w SJPDor aż 15 na 22 leksemów uzyskało adnotację o reprezentowaniu dziedziny: sportu (bookmacher, derby, falstart, handicap, krótkodystansowiec, miler, outsider, przedbieg, przeszkodowiec, sprinter, walkower), zoologii (eksterier), zootechniki (inbred, mesz); kwalifikatorem chronologicznym dawny zaopatrzono zaś rzeczownik turf.

Pozostała grupę pożyczek, jednocześnie najbardziej liczebna, stanowia leksemy, które nie zostały odnotowane w żadnym $z$ wybranych słowników języka polskiego: 69 anglicyzmów, 2 germanizmy i 2 galicyzmy. Trzeba dodać, że pod względem strukturalnym część zbioru wypełniaja kompozycje, które okazały się w największym stopniu efemeryczne. Okazjonalnościa cechowała się także ta część pożyczek formal- 
nosemantycznych, które w chwili zasilenia zasobu leksykalnego języka polskiego miały odpowiedniki bądź rodzime, bądź zapożyczone i już przyswojone, bądź szybko takie odpowiedniki znalazły, wskutek czego stały się elementem nadmiarowym, zbędnym, toteż zostały w krótkim czasie usunięte ze słownictwa wyścigowego. Najtrwalsze okazały się kalki frazeologiczne, $z$ których większość funkcjonuje w tym słownictwie do dziś, a które nie zostały odnotowane w XX-wiecznych słownikach języka polskiego zapewne $z$ powodu przynależności do słownictwa sportowego, czyli specjalistycznego.

Spójrzmy teraz na zgromadzone wyrazy obce przez pryzmat semantyki i spróbujmy odpowiedzieć na pytanie, jak $z$ tej perspektywy wyglaca kwestia klasyfikacji genetycznej słownictwa pozostajacego w centrum naszego zainteresowania. Wyekscerpowane rzeczowniki utworzyły 14 kręgów tematycznych, które przedstawiono w poniższej tabeli.

Tabela nr 3. Kręgi tematyczne słownictwa wyścigów konnych 20-lecia międzywojennego

\begin{tabular}{|c|c|c|c|c|}
\hline $\begin{array}{c}\text { Kręgi } \\
\text { tematyczne }\end{array}$ & $\begin{array}{c}\text { Geneza } \\
\text { slownictwa }\end{array}$ & Leksemy & $\begin{array}{c}\text { Liczba } \\
\text { leksemów }\end{array}$ & $\begin{array}{c}\text { Udzial } \\
\text { [\%] }\end{array}$ \\
\hline \multirow{8}{*}{ I. Nazwy koni } & angielski & $\begin{array}{l}\text { champion, champion-fleyer, crack, derby-crack, } \\
\text { długodystansowiec, fleyer, koń wyścigowy, } \\
\text { krótkodystansowiec, leader, miler, outsider, } \\
\text { pacemaker, płotowiec, przeszkodowiec, puler, } \\
\text { racer, roarer, sprinter, stallion, steepler, stayer, } \\
\text { wyścigowiec, yearling }\end{array}$ & 23 & 9,5 \\
\hline & rodzime & $\begin{array}{l}\text { anglik, anglo-arab, arab, arabczyk, biegun, derbista, } \\
\text { dwulatek, dzieci, klacz, oaksistka, półkrewek, } \\
\text { roczniak, skoczek, steeplerka, steyerka, stępak, } \\
\text { trzylatek, źrebica, źrebiec }\end{array}$ & 18 & 7,5 \\
\hline & niemiecki & faworyt, folblut, fuks, halblut & 4 & 1,7 \\
\hline & francuski & reproduktor & 1 & 0,4 \\
\hline & łaciński & kursor & 1 & 0,4 \\
\hline & rosyjski & debiutant & 1 & 0,4 \\
\hline & czeski & szermierz & 1 & 0,4 \\
\hline & turecki & ogier & 1 & 0,4 \\
\hline \multicolumn{3}{|l|}{ Razem } & 50 & 20,7 \\
\hline
\end{tabular}


cd. tabeli nr 3

\begin{tabular}{|c|c|c|c|c|}
\hline $\begin{array}{c}\text { Kręgi } \\
\text { tematyczne }\end{array}$ & $\begin{array}{c}\text { Geneza } \\
\text { slownictwa }\end{array}$ & Leksemy & $\begin{array}{l}\text { Liczba } \\
\text { leksemów }\end{array}$ & $\begin{array}{c}\text { Udzia } \\
{[\%]}\end{array}$ \\
\hline \multirow{3}{*}{$\begin{array}{l}\text { II. Nazwy } \\
\text { gonitw } \\
\text { i nagród }\end{array}$} & angielski & $\begin{array}{l}\text { błękitna wstega, derby, gonitwa gentlemańska, } \\
\text { gonitwa klasyczna, gonitwa płaska, gonitwa } \\
\text { płotowa, gonitwa półklasyczna, gonitwa } \\
\text { pótsprzedażna, gonitwa specjalna, gonitwa } \\
\text { sprzedażna, gonitwa żokejska, handicap, match, } \\
\text { meeting, steeple-chase, walk-over, wyścigi konne }\end{array}$ & 17 & 7,1 \\
\hline & rodzime & $\begin{array}{l}\text { bieg, gonitwa, próba selekcyjna, szranki, wyścig, } \\
\text { zapasy, sezon wiosenny, sezon letni, sezon jesienny, } \\
\text { sezon zimowy, sezon płaski, sezon płotowy }\end{array}$ & 12 & 5,0 \\
\hline & francuski & championat, kurs, sezon & 3 & 1,2 \\
\hline \multicolumn{3}{|l|}{ Razem } & 32 & 13,3 \\
\hline \multirow{4}{*}{$\begin{array}{l}\text { III. Nazwy } \\
\text { osób }\end{array}$} & angielski & $\begin{array}{l}\text { backer, bookmacher, champion-żokiej, gentleman- } \\
\text { rider, handicaper, inspektor toru, jockey, } \\
\text { kontrstarter, lad, manager, sędzia u wagi, sędzia } \\
\text { u zegara, sędzia u celownika, sẹdzia handicaper, } \\
\text { sędzia starter, sędzia kontrstarter, sędzia } \\
\text { przetargów, sportsman, steward, trener, turfman }\end{array}$ & 21 & 8,7 \\
\hline & rodzime & $\begin{array}{l}\text { angloman, araboman, chłopiec, eksterierzysta, } \\
\text { gracz, hippolog, jeździec, koniuszy, stajenny }\end{array}$ & 9 & 3,7 \\
\hline & łaciński & komisarz & 1 & 0,4 \\
\hline & niemiecki & futtermeister & 1 & 0,4 \\
\hline \multicolumn{3}{|l|}{ Razem } & 32 & 13,3 \\
\hline \multirow{5}{*}{$\begin{array}{l}\text { IV. Nazwy } \\
\text { miejsc } \\
\text { i obiektów }\end{array}$} & rodzime & $\begin{array}{l}\text { budka sẹdziowska, celownik, linia prosta, } \\
\text { siodlarnia, słup, słup dystansowy, stajnia, tor } \\
\text { wyścigowy, tor piaszczysty, tor zielony, trybuna } \\
\text { główna, trybuna członkowska, trybuna sędziowska }\end{array}$ & 13 & 5,4 \\
\hline & angielski & $\begin{array}{l}\text { beeting-room, boks, paddock, plac wyścigowy, }{ }^{8} \text { pole } \\
\text { wyścigowe, start-maszyna, tor klasyczny, } \\
\text { tor prowincjonalny, turf }\end{array}$ & 9 & 3,7 \\
\hline & francuski & bariera, promenada, trybuna & 3 & 1,2 \\
\hline & grecki & hipodrom & 1 & 0,4 \\
\hline & niemiecki & banda & 1 & 0,4 \\
\hline \multicolumn{3}{|l|}{ Razem } & 27 & 11,2 \\
\hline
\end{tabular}

8 SWil notuje plac wyścigów. 


\section{cd. tabeli nr 3}

\begin{tabular}{|c|c|c|c|c|}
\hline $\begin{array}{c}\text { Kręgi } \\
\text { tematyczne }\end{array}$ & $\begin{array}{c}\text { Geneza } \\
\text { slownictwa }\end{array}$ & Leksemy & $\begin{array}{c}\text { Liczba } \\
\text { leksemów }\end{array}$ & $\begin{array}{c}\text { Udzial } \\
{[\%]}\end{array}$ \\
\hline \multirow{4}{*}{$\begin{array}{l}\text { V. Cechy } \\
\text { fizyczne } \\
\text { i dziedziczne } \\
\text { konia } \\
\text { wyścigowego }\end{array}$} & angielski & $\begin{array}{l}\text { fitness, inbreed, pedigree, speed, halfspeed, } \\
\text { fullspeed, stamina }\end{array}$ & 7 & 2,9 \\
\hline & łaciński & akcja, forma, klasa, kondycja & 4 & 1,7 \\
\hline & rodzime & pochodzenie, prady krwi, rodowód & 3 & 1,2 \\
\hline & francuski & eksterier & 1 & 0,4 \\
\hline \multicolumn{3}{|l|}{ Razem } & 15 & 6,2 \\
\hline \multirow{5}{*}{$\begin{array}{l}\text { VI. Nazwy } \\
\text { i czynności } \\
\text { związane } \\
\text { z przebiegiem } \\
\text { gonitwy }\end{array}$} & angielski & derby-dystans, finisz, performance, rekord, start & 5 & 2,1 \\
\hline & francuski & dystans, karambol, rezultat, taktyka & 4 & 1,7 \\
\hline & rodzime & klatka, walka, zwyciesstwo & 3 & 1,2 \\
\hline & rosyjski & debiut & 1 & 0,4 \\
\hline & łaciński & meta & 1 & 0,4 \\
\hline \multicolumn{3}{|l|}{ Razem } & 14 & 5,8 \\
\hline \multirow{4}{*}{$\begin{array}{l}\text { VII. Nazwy } \\
\text { i czynności } \\
\text { związane } \\
\text { z poruszaniem } \\
\text { się konia }\end{array}$} & angielski & canter, forcanter, pace, przedbieg, rush, stride, trial & 7 & 2,9 \\
\hline & rodzime & mach, rzut & 2 & 0,8 \\
\hline & francuski & galop, kontrgalop & 2 & 0,8 \\
\hline & niemiecki & kurcgalop, szpryca & 2 & 0,8 \\
\hline \multicolumn{3}{|l|}{ Razem } & 13 & 5,4 \\
\hline \multirow{6}{*}{$\begin{array}{l}\text { VIII. Nazwy } \\
\text { zwiazane } \\
\text { ze strojem } \\
\text { wyścigowym }\end{array}$} & rodzime & bat, czapka, kurtka, ołów, ścierka, trzcinka & 6 & 2,5 \\
\hline & łaciński & kolory, okulary & 2 & 0,8 \\
\hline & niemiecki & barwy, rynsztunek & 2 & 0,8 \\
\hline & angielski & dres & 1 & 0,4 \\
\hline & turecki & czaprak & 1 & 0,4 \\
\hline & ukraiński & derka & 1 & 0,4 \\
\hline \multicolumn{3}{|l|}{ Razem } & 13 & 5,4 \\
\hline \multirow{4}{*}{$\begin{array}{l}\text { IX. Nazwy } \\
\text { i czynności } \\
\text { związane } z \text { gra } \\
\text { w totalizatora }\end{array}$} & francuski & bilet, doubla, pula, totalizator, typ & 5 & 2,1 \\
\hline & rodzime & cofnięcie, stawka, zakład & 3 & 1,2 \\
\hline & angielski & cota & 1 & 0,4 \\
\hline & łaciński & figura & 1 & 0,4 \\
\hline \multicolumn{3}{|l|}{ Razem } & 10 & 4,1 \\
\hline
\end{tabular}




\section{cd. tabeli nr 3}

\begin{tabular}{|c|c|c|c|c|}
\hline $\begin{array}{c}\text { Kręgi } \\
\text { tematyczne }\end{array}$ & $\begin{array}{c}\text { Geneza } \\
\text { slownictwa }\end{array}$ & Leksemy & $\begin{array}{c}\text { Liczba } \\
\text { leksemów }\end{array}$ & $\begin{array}{l}\text { Udział } \\
{[\%]}\end{array}$ \\
\hline \multirow{4}{*}{$\begin{array}{l}\text { X. Nazwy } \\
\text { i czynności } \\
\text { będące } \\
\text { warunkiem } \\
\text { uczestnictwa } \\
\text { w wyścigu }\end{array}$} & rodzime & mianowanie, przepadek, stawka, zapis & 4 & 1,7 \\
\hline & angielski & instrukcja, sweepstakes, top-weight, ulga wagi & 4 & 1,7 \\
\hline & niemiecki & licytacja, meldunek & 2 & 0,8 \\
\hline & francuski & dyspozycja & 1 & 0,4 \\
\hline \multicolumn{3}{|l|}{ Razem } & 11 & 4,6 \\
\hline \multirow{4}{*}{$\begin{array}{l}\text { XI. Nazwy } \\
\text { przewinień } \\
\text { i kar }\end{array}$} & rodzime & ostrzeżenie, skarga, spieszenie, wyrok & 4 & 1,7 \\
\hline & angielski & crossen, doping, falstart & 3 & 1,2 \\
\hline & francuski & dyskwalifikacja & 1 & 0,4 \\
\hline & niemiecki & protest & 1 & 0,4 \\
\hline \multicolumn{3}{|l|}{ Razem } & 9 & 3,7 \\
\hline \multirow{3}{*}{$\begin{array}{l}\text { XII. Nazwy } \\
\text { zbiorowe koni }\end{array}$} & rodzime & dzieci, przychówek, stawka, towarzystwo & 4 & 1,7 \\
\hline & francuski & depo & 1 & 0,4 \\
\hline & niemiecki & kompania & 1 & 0,4 \\
\hline \multicolumn{3}{|l|}{ Razem } & 6 & 2,5 \\
\hline $\begin{array}{l}\text { XIII. Nazwy } \\
\text { publikacji }\end{array}$ & angielski & $\begin{array}{l}\text { book, kalendarz kursowy, ksiegga stadna, prawidła } \\
\text { wyścigowe, program wyścigowy, studbuch }\end{array}$ & 6 & 2,5 \\
\hline \multicolumn{3}{|l|}{ Razem } & 6 & 2,5 \\
\hline \multirow{2}{*}{$\begin{array}{l}\text { XIV. Nazwy } \\
\text { związane } \\
\text { z treningiem }\end{array}$} & angielski & mash, trening & 2 & 0,8 \\
\hline & rodzime & robota & 1 & 0,4 \\
\hline \multicolumn{3}{|l|}{ Razem } & 3 & 1,2 \\
\hline \multicolumn{3}{|l|}{ Lącznie } & 241 & 100,0 \\
\hline
\end{tabular}

$\mathrm{Na}$ podstawie zaprezentowanych danych statystycznych możemy stwierdzić, że pod względem liczebności rysuje się podział na trzy zbiory: największy (kręgi tematyczne od I do IV), średni (od V do X) i najmniejszy (od XI do XIV). W odniesieniu do istotnej dla nas kwestii wyrazów zapożyczonych należy stwierdzić, że są one obecne we wszystkich czternastu zbiorach, a przeważają aż w trzynastu $z$ nich. Powyższe dowodzi, że potrzeby kompletacji słownictwa droga przejmowania wyrazów obcych były bardzo silne i wystapiły we wszystkich kręgach tematycznych słownictwa dotyczącego wyścigów konnych. 
Rozpatrując jednostki leksykalne przypisane do poszczególnych kręgów tematycznych, warto zwrócić uwagę na występowanie ciagów wyrazów synonimicznych. Świadczy to o tym, że w 20-leciu międzywojennym nie skrystalizował się jeszcze trzon słownictwa zwiazanego $z$ wyścigami konnymi, a zapożyczenia związane $z$ nową konkurencja sportowa napływały do polszczyzny szeroka falą i w szybkim tempie. Egzemplifikację tego procesu stanowia takie ciagi jak np.: biegun - kursor - racer - szermierz - wyścigowiec, bieg - gonitwa - próba selekcyjna - szranki - wyścig - zapasy - kurs - match - meeting, stallion - ogier, roczniak - yearling, sprinter - krótkodystansowiec, stayer - długodystansowiec, steepler - przeszkodowiec - płotowiec - skoczek, leader - pacemaker, anglo-arab-półkrewek - halblut, anglik-folblut, derbista-derby-crack, chłopiec-lad, jeździec-dżokej, koniuszy - futtermeister, tor - turf-hippodrom, pochodzenie - rodowód - pedigree, fitness - forma - kondycja, galop - canter, przedbieg - forcanter, rzut-rush, dres-rynsztunek, pole - stawka - towarzystwo - kompania, ksiega stadna - book - studbuch, robota-trening.

Podsumowując, trzeba stwierdzić, że analiza przedstawiona w niniejszym artykule pozwala na sformułowanie kilku wniosków. Po pierwsze, ukonstytuowanie zasobu leksykalnego nowej dyscypliny sportu, która były w 20-leciu międzywojennym wyścigi konne, w dużym stopniu było zależne od czynników zewnętrznojęzykowych. W zwiąku z tym, że sport ten przybył na ziemie polskie $z$ Wielkiej Brytanii i $z$ Francji, trzon słownictwa obcego stanowiły okcydentalizmy przede wszystkim w postaci anglicyzmów. Po drugie, rozpatrujac wyrazy obce $z$ perspektywy chronologii, należy stwierdzić, że zaledwie $16 \%$ to zapożyczenia dawne, przejęte do polszczyzny do początku XIX w., a głównym mechanizmem ich przystosowania do funkcjonowania w obrębie słownictwa sportowego była neosemantyzacja (homonimizacja); $84 \%$ to pożyczki nowe, napływajace od połowy XIX w., z których około 60\% nie przekroczyło cezury 1939 r. Po trzecie, wyekscerpowany materiał leksykalny ukazuje wzmożony proces adaptacji zapożyczeń do systemu gramatycznego polszczyzny, co przejawia się chociażby we współwystępowaniu odmiennych i nieodmiennych form tego samego rzeczownika. Po czwarte, analizując rzeczowniki rodzime i obce $z$ perspektywy semantyki, trzeba wskazać, że w co najmniej kilku kręgach tematycznych widać wyraźne nagromadzenie słownictwa bliskoznacznego, co z punktu widzenia stopnia skompletowania analizowanego zasobu leksykalnego świadczy o występowaniu elementów nadmiarowych.

Wszystkie zasygnalizowane zagadnienia wskazuja, że badany przeze mnie krag słownictwa nie był jeszcze ustabilizowany w okresie 20-lecia międzywojennego, podlegał dynamicznym przemianom, które dokonywały się na poszczególnych płaszczyznach systemu językowego. Spoglądając na prezentowany zasób leksykalny, możemy stwierdzić, że 
jesteśmy świadkami sui generis etapu jego przewartościowywania, po którym zgodnie $z$ prawami rozwoju języka nastapić powinno usuwanie elementów wspólnofunkcyjnych, a zatem zbędnych $z$ punktu widzenia tendencji systemu językowego do ekonomiczności. ${ }^{9}$ Odpowiedź na pytanie, czy takie właśnie były losy słownictwa wyścigów konnych, wymaga osobnego omówienia.

\section{Bibliografia}

S. Dubisz, Język - historia - kultura (wykłady, studia, analizy), t. I, Warszawa 2002.

H. Karaś, Rusycyzmy słownikowe w polszczyźnie okresu zaborów, Warszawa 1996.

B. Nowowiejski, Zapożyczenia leksykalne z języka niemieckiego $w$ polszczyźnie XIX wieku (na materiale czasopism), Białystok 1996.

J. Ożdżyński, Polskie współczesne słownictwo sportowe, Wrocław-WarszawaKraków 1970.

W. Pruski, Dzieje wyścigów i hodowli koni pelnej krwi angielskiej w Polsce. Królestwo Polskie 1815-1918, Warszawa 1970.

W. Pruski, Wyścigi i hodowla koni petnej krwi oraz czystej krwi arabskiej w Polsce w latach 1918-1939, Wrocław-Warszawa-Kraków-Gdańsk 1980.

\section{Słowniki}

W. Doroszewski (red.), Słownik języka polskiego, t. 1-11, Warszawa 1958-1969.

S. Dubisz (red. nauk.), Uniwersalny słownik języka polskiego, t. I-IV, Warszawa 2008.

J. Karłowicz, A. Kryński, W. Niedźwiedzki (red.), Słownik języka polskiego, t. 1-8, Warszawa 1900-1927.

S.B. Linde, Słownik jezyka polskiego, t. 1-6, Warszawa 1807-1815.

M. Orgelbrand (wyd.), Słownik języka polskiego, t. 1-2, Wilno 1861.

\section{Material źródłowy}

"Jeździec i Hodowca” 1922, nr 1, 16, 17, 2, 22, 23, 34, 35, 48.

„Jeździec i Hodowca” 1923, nr 8, 23, 24.

„Jeździec i Hodowca” 1924, nr 1-2, 3-4.

„Jeździec i Hodowca” 1926, nr 19-20.

„Jeździec i Hodowca” 1927, nr 13-14, 17, 20, 25.

„Jeździec i Hodowca” 1928, nr 23.

"Jeździec i Hodowca” 1929, nr 5.

„Jeździec i Hodowca” 1930, nr 27, 37.

"Jeździec i Hodowca" 1931, nr 23.

„Jeździec i Hodowca” 1932, nr 4, 5, 6, 8, 10, 19, 20, 42.

„Jeździec i Hodowca” 1933, nr 7, 8, 16, 18, 26.

9 O kierunku głównych tendencji rozwojowych systemu językowego polszczyzny na przestrzeni dziejów zob.: S. Dubisz, Język - historia - kultura (wykłady, studia, analizy), t. I, Warszawa 2002, s. 25-44. 
„Jeździec i Hodowca” 1934, nr 15, 16.

„Jeździec i Hodowca” 1935, nr 16, 17, 18.

"Jeździec i Hodowca” 1936, nr 14, 20, 25, 27, 30.

"Jeździec i Hodowca” 1937, nr 6, 11, 20, 32.

„Jeździec i Hodowca” 1938, nr 11, 12, 13, 15, 16, 20, 26, 28.

„Jeździec i Hodowca” 1939, nr 38.

\section{Borrowings in the horse-racing vocabulary of the interwar period (on the basis of the "Jeździec i Hodowca" ("Rider and breeder") magazine)}

\section{Summary}

This paper represents the stream of structuralist research and has been dedicated to discussing a selected portion of the sports vocabulary of the interwar period. On the basis of the "Jeździec i hodowca" ("Rider and breeder") magazine, foreign words present in the horse-racing vocabulary have been analysed. The research concentrates on describing the chronology and genetics of the borrowings, their registration in selected lexicographic sources, and the thematic circles they represent. The conclusion of this paper indicates that a large portion of the vocabulary borrowed from horse races was not stabilized and was subject to adaptation to the Polish language system in the selected period.

Keywords: structuralism - history of Polish $-20^{\text {th }}$ century - sports vocabulary - horse-racing vocabulary - vocabulary of Polish magazines form the period 1918-1939 - borrowings - thematic circles - statistical method of examining vocabulary. 
Dorota Zdunkiewicz-Jedynak

DOI: 10.33896/PorJ.2021.4.5

(Uniwersytet Warszawski,

e-mail: d.jedynak@uw.edu.pl)

ORCID: 0000-0002-4710-9826

\section{INFORMACJA PRAGMATYCZNA W SLOWNIKU ORTOEPICZNYM. STAN OBECNY I POTRZEBY}

\section{PRAGMATYKA - ROZUMIENIE POJĘCIA}

Termin pragmatyka najczęściej dziś jest wiązany $z$ mechanizmami rozumienia $i$ interpretowania wypowiedzi $z$ uwzględnieniem kontekstu, z „działaniem człowieka poprzez użycie środków językowych” [Kalisz 1993 , 9]. Piotr Stalmaszczyk nazywa to ujęcie pragmatyki prakseologicznym [Stalmaszczyk 2008, 17]. $Z$ takim rozumieniem pragmatyki oswoiliśmy się w lingwistyce pod wpływem teorii aktów mowy i teorii implikatur.

W kontekście pracy nad nową koncepcją słownika ortoepicznego stosowniejszy jednak wydaje się powrót do pierwotnego rozumienia pragmatyki (ujmowanej jako element triady: semantyka, składnia, pragmatyka). Pojawiło się - przypomnijmy - na gruncie logiki, w obrębie teorii semiotycznej. Jej autorem jest Charles Morris. Według amerykańskiego filozofa syntaktyka bada relacje składniowe zachodzacce pomiędzy znakami, semantyka zajmuje się relacją między znakami a obiektami, które są lub moga być denotowane przez znaki, pragmatyka zaś dotyczy relacji zachodzących pomiędzy znakami a ich interpretatorami [Morris 1938, 30; por. Stalmaszczyk 2008, 13].

Ujęcie semiotyczne zasadniczo jest również akceptowane na gruncie lingwistyki, stanowiło nawet źródło inspiracji wielu prac językoznawczych [por. np. Stalnaker 1970, 272-289; 1972; Montague 1968; 1974, 95-118; Gazdar 1979, 2]. Ten ostatni badacz pod koniec lat 70. XX w. zaproponowal, by pragmatykę wiązać $z$ takimi aspektami wypowiedzi, których nie można przedstawić, odwołując się do warunków prawdziwości [Gazdar 1979, 2; por. Stalmaszczyk 2008, 15].

Wśród współczesnych podejść do pragmatyki za najbardziej przydatne i inspirujące w kontekście nowoczesnego słownika ortoepicznego opartego na aktualnych rozwiazaniach metodologicznych i odpowiadajacego nowym wyzwaniom komunikacyjnym oraz dzisiejszym potrzebom użytkowników języka wydaja się propozycje rozumienia pragmatyki osadzone w praktyce leksykograficznej, w szczególności zaś pomysły Jurija Apresjana i Andrzeja Bogusławskiego. W koncepcjach obu badaczy punktem odniesienia terminu pragmatyka sa wy rażenia językowe, a nie - akty mowy. Obie propozycje w zakresie leksykograficznego rozróżnia- 
nia semantyki i pragmatyki powinny być wzięte pod uwagę we współczesnych leksykograficznych przedsięwzięciach ortoepicznych.

W ramach koncepcji całościowego opisu języka rosyjski językoznawca i leksykograf sformułował następującą definicję pragmatyki:

Terminem pragmatyka będziemy określać utrwalony w jednos tce językowej (w leksemie, afiksie, gramemie, konstrukcji składniowej) stosunek mówiącego:

(1) do rzeczywistości,

(2) do treści wypowiedzi,

(3) do adresata.

Należy podkreślić, że chodzi nam nie o ocenę dokonywaną przez mówiącego w wypowiedzi, lecz o ocenę zleksykalizowana lub zgramatykalizowana, która wbudowana jest bezpośrednio w plan treści jednostek językowych i ma w zwiąku z tym określony stały status w języku [Apresjan (1988) 2012, 42].

J. Apresjan, biorąc pod uwage pragmatyczny aspekt jednostki języka, pisał w innym miejscu:

Należy do niej szeroki krag zjawisk, poczynając od elementów ekspresywnych znaczenia (...), a kończąc na tych modalnych składnikach znaczenia (związanych nie $z$ opisywaną sytuacja, lecz z sytuacją komunikacji), które A. Wierzbicka opisywała jako ramę modalną wyrażenia, a Ch. Fillmore jako presupozycję [Apresjan (1974) 2000, 76].

Według J. Apresjana informacja pragmatyczna ma trzy cechy:

1) jest wyrażana językowymi środkami peryferyjnymi (w porównaniu ze środkami wyrażania informacji semantycznej; oznacza to na przykład, że w podstawowych znaczeniach wyrazów udział czystej semantyki jest większy niż w znaczeniach przenośnych czy frazeologicznie powiazanych);

2) dysponujemy różnymi środkami językowymi do jej przekazywania, tzn. brak możliwości jej lokalizacji w jakiejś jednej jednostce języka;

3) ściśle powiązana jest $z$ informacją semantyczną.

Główne typy informacji pragmatycznej to według rosyjskiego lingwisty [por. Apresjan (1988) 2012, 52-53]:

- kwalifikacja stylistyczna (także komponent oceniający),

- takie cechy leksemu jak performatywność lub inna nietypowa funkcja illokucyjna,

- status nadawcy i odbiorcy pod względem wieku, hierarchii społecznej lub innej,

- konotacje.

Oryginalna propozycje ujmowania pragmatycznych właściwości jednostek języka przedstawili również Andrzej Bogusławski i Jan Wawrzyńczyk [Bogusławski, Wawrzyńczyk 1993, zob. także wcześniej Bogusławski 1973, 121-151; Bogusławski, Garnysz-Kozłowska 1979, 301-326] oraz kontynuatorzy projektu Sondy słownikowej [por. Bogusławski, Danielewiczowa 2005]. Autorzy za pragmatyczne uznają cztery kategorie właściwości wyrażeń: 
- właściwości a k o m o d a cyj n e (zasięgu, relacyjne i sytuacyjne),

- właściwości emotywne,

- właściwości praktyczne,

- właściwości poetyckie.

Poszczególnym kategoriom odpowiadają w ujęciu autorów określone kwalifikatory pragmatyczne.

A k o m o d a cj a odpowiada wyborowi stylistycznemu. Zwiazana jest $z$ takimi właściwościami wyrażeń, które wynikają $z$ ich przystosowania do określonych zakresów (kręgów) użycia. Zakresy te istnieją niezależnie od intencji mówiącego [por. Bogusławski, Wawrzyńczyk 1993, 33]. Autorzy wyróżniaja 3 rodzaje tak rozumianej akomodacji (przystosowania):

- akomodacja zasięgu - o właściwościach zasięgu informuja takie kwalifikatory jak: środ. (wyrażenie o zasięgu ograniczonym do pewnego środowiska wskazanego jednak ogólnie), profesj. (wyrażenie o zasięgu ograniczonym do grupy zawodowej), nowe (wyrażenie świeżo lub relatywnie świeżo wprowadzone do użytku, nieposiadające ustabilizowanej „afiliacji” środowiskowej lub statusu powszechności), daw. (wyrażenie dawne, czyli używane przez przedstawicieli pokolenia nieżyjącego lub wygasającego), młodz. (wyrażenie młodzieżowe), dziec. (wyrażenie używane przez dzieci lub dorosłych zwracających się do dzieci) [zob. Bogusławski, Wawrzyńczyk 1993, 33-34];

- akomodacja relacyjna, gdy czynnikiem rozstrzygajacym o możliwości wyboru jednostki sa towarzysko-społeczne relacje między nadawca a odbiorca wypowiedzi (jak hierarchiczność, stopień zażyłości), nadawca a słuchaczem niebędącym bezpośrednim odbiorca (adresatem wypowiedzi) oraz relacja między nadawca a bohaterem wypowiedzi [por. Huszcza 2006, 47); właściwościom relacyjnym autorzy przyporzadkowali takie kwalifikatory jak: famil. (wyrażenie familiarne, stosowane w relacjach swobodnych i intymnych), antyfamil. (wyrażenie antyfamiliarne), humil. (wyrażenie humilizacyjne, pokornościowe), oględ. (wyrażenie oględne służące stonowaniu wypowiedzi), godn. (wyrażenie godnościowe) [zob. Bogusławski, Wawrzyńczyk 1993, 34];

- akomodacja sytuacyjna, gdy czynnikiem ograniczajacym użycie jednostki jest typ sytuacji mownej, odpowiadajacy kręgom życia społecznego; ze względu na akomodację sytuacyjna wyrażeniom przypisywane sa tzw. rejestry stylistyczne - odpowiadaja im takie kwalifikatory jak: urocz. (wyrażenie uroczyste), urzęd. (wyrażenie urzędowe), oficj. (wyrażenie oficjalne), ksiażk. (wyrażenie książkowe), public. (wyrażenie publicystyczne), pot. (wyrażenie potoczne), posp. (wyrażenie pospolite, czyli takie, którego użycie narusza savoir vivre), ordyn. (wyrażenie ordynarne, mogace stanowić obrazę), eufem. (wyrażenie eufemistyczne, używane zamiast wyrażenia tabu), nieeufem. (wyrażenie nieeufemistyczne, czyli takie, na który nałożony jest zakaz tabuistyczny) [zob. Bogusławski, Wawrzyńczyk 1993, 34]. 
E m o tyw n oś ć w ujęciu A. Bogusławskiego i J. Wawrzyńczyka jest właściwościa wyrażeń pozwalająca na wprowadzenie odbiorcy w określony stan emocjonalny. Na tę kategorię składaja się kwalifikatory: pieszcz. (wyrażenie pieszczotliwe), rub. (wyrażenie rubaszne), niegrz. (wyrażenie niegrzeczne), lekcew. (wyrażenie lekceważące), pogard. (wyrażenie pogardliwe), piętn. (wyrażenie piętnujace), eufor. (wyrażenie euforyczne, wprowadzające nastrój radosnego podniecenia), minor. (wyrażenie minorowe, wprowadzające nastrój depresyjny, rozczarowania, goryczy) [zob. Bogusławski, Wawrzyńczyk 1993, 34].

Właściwości praktyczne wyrażeń wreszcie sa wyznaczane przez zachowanie się odbiorcy i/lub nadawcy w ich działaniach pozapoznawczych. Właściwościom tym odpowiadają w ujęciu A. Bogusławskiego 3 kwalifikatory: perform. (wyrażenie performatywne), quasi-perform. (wyrażenie quasi-performatywne - towarzyszy rzekomemu magicznemu stwarzaniu stanu rzeczy), behab. (wyrażenie behabitywne - gdy wyrażenie towarzyszy zachowaniom symbolicznym, niemajacym funkcji reprezentatywnej, takim jak powitania, pożegnania, odzywki karciane itp.) [zob. Bogusławski, Wawrzyńczyk 1993, 34].

Właściwości poetyckie dla odmiany wprowadzaja do wypowiedzi efekty ludyczne i zdobnicze. Kategoria obejmuje 8 kwalifikatorów: rytmiz. (wyrażenie rytmizowane), wyszuk. (wyrażenie wyszukane), arch. (wyrażenie archaizujące), obr. (wyrażenie obrazowe), żart. (wyrażenie żartobliwe), iron. (wyrażenie ironizujące), litota (wyrażenie łagodzace), peryfr. (wyrażenie peryfrastyczne).

\section{INFORMACJA PRAGMATYCZNA W WSPP}

Przegląd ostatniego, najbardziej wśród użytkowników języka znanego słownika ortoepicznego - Wielkiego słownika poprawnej polszczyzny pod redakcją Andrzeja Markowskiego [Markowski (red.) 2018] - uwzględniający przedstawiony w leksykonie rejestr kwalifikatorów oraz częstość ich rzeczywistego zastosowania w opisach haseł pozwala stwierdzić, że $\mathrm{w}$ tym słowniku informacja pragmatyczna odnosi się przede wszystkim do normy w zakresie akomodacji zasięgu środowiskowego (np. rejestr tego typu kwalifikatorów jest najliczniej reprezentowany, np. aktor., bud., dzien., farm., rad., środ., socjol., techn., teatr., uczn., filoz., fiz., górn., kośc., łow., młodz., mor., muz., nark., naucz., rel., żołn., żegl., daw., przestarz., hist.), poszerzonej tu o zas ięg te ry torialny (np. reg., st., warm., wielkopol., wsch., zach., białost., ciesz., gw., krak., podh., lwow., małop., maz., pd.), dalej akomodacji sytuacyjnej (np. posp., pot., erud., eufem., ksiażk., nauk., oficj., publ., urzędow.), wreszcie właściwości e motywnych (opisuja tę właściwość jednostek takie kwalifikatory jak: ekspr., lekc., obraźl., obelż., pieszczot., pogard., żart.). W stopniu o wiele mniejszym reprezentowana jest w tym 
słowniku informacja normatywna dotyczacca a ko mo dacji rela cyjn ej (opisywanej bodaj tylko przez kwalifikator pouf.) i wła ściw oś ci p o e tyckie (odpowiednio sygnalizowane kwalifikatorami iron., żart.). W tym słowniku informacja pragmatyczna ma zreszta - jak się zdaje - charakter drugoplanowy, a może lepiej powiedzieć: służebny - jest konsekwencja przyjętej w tym słowniku koncepcji normy dwupoziomowej (wzorcowej i użytkowej), dlatego kwalifikator stylistyczny pot. nierzadko jest sprzęgnięty z kwalifikatorem normatywnym potocznie dopuszczalne. Ponadto zasadniczym przedmiotem kodyfikacji normy językowej w tym opracowaniu są właściwości ściśle semantyczne i gramatyczne opisywanych jednostek, a nie ich wartość pragmatyczna, tak jakby w praktyce użytkowników języka ta sfera własności jednostek języka nie podlegała społecznej normalizacji.

Przy okazji: niejasny jest status kwalifikatorów lepsze (lepiej) i gorsze (gorzej) - w nowoczesnym słowniku opartym na badaniach korpusowych i statystycznych należałoby $z$ nich zrezygnować - ich stosowanie w WSPP nosi wyraźne znamiona subiektywizmu. Ocena redaktorów w słowniku normatywnym na miarę XXI wieku powinna być „wchłonięta” przez jakiś kwalifikator obiektywizujący odwołujący się do pragmatycznego czynnika autorytetu kwestion. ( $\mathrm{z}$ uzupełnieniem: ze względu na...).

\section{KOMPONENT PRAGMATYCZNY W ŚWIADOMOŚCI UŻYTKOWNIKÓW JĘZYKA}

Korespondencja internetowych poradni językowych pokazuje, że wiele $z$ zadawanych przez użytkowników języka pytań dotyczy takich aspektów posługiwania się jednostkami języka, które mają charakter czysto pragmatyczny - i to w sensie znacznie szerszym niż tylko akomodacja stylistyczna:

Witam, czy na spotkaniu firmowym, przedstawiajac szefową firmy, bard zi ej po p r aw n i e będzie powiedzieć: „A teraz przedstawiam go s pody nię dzisiejszego spotkania, panią Annę Kowalska", czy też należy użyć słowa go s podarz?

Szanowni Państwo, ostatnio byłem świadkiem sytuacji, w której student zwrócił się do pani profesor: Czy jest dziś na wydziale pani maż?. Chodzi oczywiście o to, że mąż pani profesor również pracuje na uczelni. Wobec różnicy w hierarchii ja bym na jego miejscu zapytał neutralnie o pana profesora X. W moim odczuciu taka wypowiedź jak jego niejako eksponuje sytuację prywatna osoby wyżej usytuowanej, co odbieram jako nietaktowne. Ale może jestem przewrażliwiony, dlatego proszę o opinię.

Szanowni Państwo, mój syn jest ateista, i w związku z tym nie uczęszcza na zdjęciach $z$ religii. W szkole zwrócono mu uwagę że niepoprawnie wita (dzień dobry) oraz tytułuje (per pan) księdza. Jak poprawnie powinien zwracać się do księdza ateista?

Czy mówienie (pisanie) o siedemdziesięcioletniej obcej kobiecie babcia, a o mężczyźnie dziadek jest zgodne $z$ polską etykietą językową? 
Jak będzie p o praw ni e: zaproponować osobę Jana Nowaka czy zaproponować osobe pana Jana Nowaka?

Szanowni Państwo, chciałabym zapytać, czy w pewnych sytuacjach mo ż n a u z n ać za dopuszczalny zwrot Szanowna Pani Anno? Pytanie dotyczy sytuacji, gdy zwracam się do kogoś, kogo dobrze znam, ale kto znajduje się wyżej w hierarchii. Oczywiście jeśli ta osoba ma jakiś tytuł lub zajmuje jakieś stanowisko, to piszę: Pani Doktor / Dyrektor, sa jednak sytuacje, gdy nie ma takiej możliwości, a Szanowna Pani wydaje się zbyt formalne.

Politycy używają sformułowania Pan Prezydent. Gdy prezydentem jakiegoś kraju jest kobieta (np. do niedawna Pani Prezydent Republiki Korei Park Geun-hye) sformułowanie Pani Prezydent jest trafne, gdyż oprócz wyrazu szacunku i podkreślenia stanowiska (Prezydent) wiadomo jest że Prezydent jest kobietą (Pani). Czy słowo Pan przed słowem Prezydent jest pleonazmem? Przecież sama forma (Prezydent) wskazuje na mężczyznę. Rozumiem, że w wołaczu lepiej dodać słowo pan [https://sjp.pwn.pl/poradnia; dostęp: 12.10. 2020].

Dla korespondentów poradni językowych (a zapewne - w ogóle dla zwykłych użytkowników języka niespecjalistów) język stanowi pewne kontinuum, w którym granica między semantyką a pragmatyką ma charakter rozmyty, a zjawiska $z$ obu płaszczyzn w naturalny sposób odnoszone są do pojęcia normy językowej, na której przestrzeganiu użytkownikom zależy w tym samym stopniu w odniesieniu do sfery semantycznej jak pragmatycznej - wszak w obu wypadkach pytaja o p o p raw ność.

Zgłaszane przez nich problemy pokazuja, że w świadomości użytkowników języka w ła ś c i w e użycie jednostek językowych nie ogranicza się do pozostawania w zgodzie $z$ regułami gramatyki czy respektowania sensu stricto $\mathrm{z} n$ a c $z$ e $n$ i a jednostek. Stanowi o nim również adekwatny pragmatycznie ich wybór spośród dostępnych środków języka - taki odpowiedni wybór jest pochodna znajomości ich właściwości wynikających $z$ określonych akceptowalnych zakresów ich użycia - istniejących niezależnie od intencji mówiącego, a także świadomość, co w praktyce za pomoca tych środków można osiagać. Chodzi tu więc zarówno o uwzględniane dotąd $\mathrm{w}$ tradycji ortoepicznej w największym stopniu przystosowania s y tu a cyj n e (społeczny typ sytuacji mownej odpowiadający kręgom życia społecznego) i przystosowania ś rod ow is kow e (np. w grupach zawodowych czy osób połączonych wspólnym hobby), jak i dotąd zwykle pomijane - ograniczenia r ela cyj n e (gdy istotne sa zwiazki, relacje między nadawca a odbiorcami, w tym kwestie zwiazane $z$ grzecznościa albo etyka słowa) czy właściwości praktyc zne. Z punktu widzenia leksykografa (ale i z perspektywy użytkownika słownika ortoepicznego) takie informacje sa dla komunikacji ważne. Sygnalizują bowiem ważne praktyczne konsekwencje użycia w tekście określonej jednostki językowej, wyboru tego, a nie innego wyrazu spośród środków oferowanych przez język. 


\section{INFORMACJA PRAGMATYCZNA W SEOWNIKU POPRAWNOŚCIOWYM A ROZUMIENIE KULTURY JĘZYKA}

Za wprowadzaniem w słowniku ortoepicznym w szerszym niż dotąd zakresie informacji pragmatycznej przemawiaja $i$ inne argumenty - chodzi o pewną filozofię uprawiania kultury języka, której wyrazem sa słowniki poprawnościowe, oraz o uwzględnienie bieżacych potrzeb komunikacyjnych native speakerów. Od lat 80. XX w. część językoznawców (przede wszystkim Jadwiga Puzynina) apelowała, by działania kulturalnojęzykowe kształtowały wrażliwość na użycia języka nie tylko niepoprawne, lecz także niewłaściwe pod względem pragmatycznym [por. np. Markowski, Puzynina 1993].

Osiagnięta po 1989 roku wolność słowa pozwalająca nam na nieskrępowane wyrażanie indywidualnych opinii, pluralizm życia publicznego maja nie tylko zalety, są także w dyskursie publicznym źródłem nadużyć, takich jak narastająca b ru ta li z a cj a zachowań językowych objawiająca się m.in. wulgary za cją czy obecnościa w dyskursie publicznym wyrażeń o b r aźli w y c h; wykluczająca mowa n i e n a w i ś c i, prowadzaca dziś do licznych procesów sądowych o zniesławienie. Rozwój nowych mediów, zwłaszcza dającego poczucie anonimowości i powszechnie dostępnego Internetu, otwiera drogę dla nieznanych w XX wieku, gdy powstawały 3 wielkie opracowania ortoepiczne [Szober 1937; 1948; Doroszewski (red.) 1976; Markowski (red.) 2012], zachowań językowych niewłaściwych, jak hejt czy trollowanie. Język polityki sięgający po słownictwo emocjonalne, a przede wszystkim semantycznie nieprecyzyjne, coraz częściej nie tylko uniemożliwia społeczne porozumienie, lecz blokuje nawet szansę na jakąkolwiek dyskusję. Wyraźnie dziś zatem widać, że niewłaściwe użycia języka nie ograniczaja się obecnie do niepoprawności gramatycznej i semantycznej.

Inny badacz - Mirosław Bańko - już ponad dekadę temu postulował, by kodyfikując normę językowa, zaakceptować wstępnie założenie, że ocena poprawności (rozumianej najogólniej jako społeczna akceptowalność) faktów językowych rzadko może być arbitralnie zero-jedynkowa. Norma językowa w ujęciu warszawskiego leksykografa obejmuje

sferę praktyki i zewnętrznych nakazów, ewentualnie uzupełniona o świadomość językową mówiących i ma charakter w i e lo p u n k t o w y, ponieważ uwzględnia ona różne punkty widzenia [Bańko 2008, 13].

\section{Bańko pisał:}

Tak jak norma wielopoziomowa, postulowana przez Kurkowska i wdrożona w NSPP, odbiera (...) ona ocenie faktów językowych charakter absolutny. O ile jednak norma wielopoziomowa relatywizuje oceny [tylko - D.J.] do sytuacji komunikacyjnych i do odmian języka (pozostając przy tym pod silnym wpływem tradycji), o tyle norma wielopunktowa uzależnia je od in ny ch okoliczności [pokreślenia D.J.]. 
Jeśli akceptuje się normę wielopunktową, za podstawę ocen normatywnych w języku można przyjąć powszechny zwyczaj albo świadomość językową mówiących, albo zewnętrzny wobec nich system zakazów i nakazów - albo wreszcie dowolną konfigurację tych czynników [tamże].

Wymieniane przez M. Bańkę czynniki mają, jak się wydaje, w większości status pragmatyczny. Przyjmując tę inspirująca koncepcję normy zaproponowana przez warszawskiego leksykografa, można sobie wyobrazić w słowniku takie pragmatyczne ze swej natury informacje o jednostkach języka, które dostarczałyby korzystającym ze słownika użytecznego i jak najobszerniejszego komentarza, w jakich okolicznościach użycie jednostki języka może być przez native speakerów lub ich część odbierane np. jako niegrzeczne, obraźliwe, deprecjonujące rozmówcę lub obiekt czy osobę, której wypowiedź dotyczy, kiedy może prowadzić do zakłóceń porozumienia między nadawca a odbiorca albo $z$ powodu ograniczonego zasięgu społecznego lub terytorialnego, albo z powodu tego, że jednostka językowa jest różnoznaczna (różnie rozumiana, semantycznie nieprecyzyjna, a nie wieloznaczna - tak jest np. w odniesieniu do wyrazów nazywających wartości). O problemie pisała i mówiła wielokrotnie Jadwiga Puzynina:

Kłopot (...) polega na tym, że granice języka wartości nawet w obrębie jednej kultury nie sa wyraźnie określone, są odmienne w ujęciu różnych osób (...). Na przykład słowo brat (w znaczeniu 'członek rodziny') dla jednych $z$ nas jest nacechowane pozytywnie, dla innych jest neutralne aksjologicznie. Podobnie jest ze słowami takimi, jak np. poezja, żotnierz, państwo, z wieloma nazwami zwierząt, miejscowości, kierunków myślowych itp. Dla części z tych nazw, a także wyrazów, które traktujemy jako niewątpliwe elementy języka wartości w danej kulturze, badania statystyczne moga wykazać wysoki procent jakiegoś nacechowania wartościującego, ale zazwyczaj nie będzie ono dotyczyć wszystkich użyć ani też obejmować wszystkich badanych. Te n nale żą cy do pragmatyki rodzaj odmienności, ujawniający się w kontaktach językowych, może powodować spory, niechęci, poczucie obcości, czasem téz tendencje do ośmieszania inaczej myślacego i ocen i a ja c e g o ${ }^{1}$ [Puzynina 2014, 8].

Użytkownicy języka, jak pokazuje praktyka korespondencyjna poradni językowych, ale również wielość sytuacji, w której językoznawcy występują w roli biegłych sądowych w sprawach o zniesławienie, maja kłopot $z$ jednoznacznym rozpoznaniem, czy mamy do czynienia $z$ obraźliwym, pogardliwym odezwaniem się do kogoś bądź o kimś. I problem ten dotyka nawet najbardziej świadomych spośród nich. Jadwiga Puzynina [Puzynina 2016] wspomina na przykład różnice w odniesieniu do rzeczownika świr, które w pragmatycznej ocenie dziela ją i Andrzeja Bogusławskiego. A. Bogusławski uważa, że świr w każdym użyciu jest słowem obraźliwym. J. Puzynina $z$ kolei jest zdania, że tego określenia można

${ }^{1}$ Wyróżnienia w tekście - D.Z.J. 
użyć w pewnych sytuacjach żartobliwie: „oj ty świrze”. Wartościowanie w tym słowie zależy od różnych czynników - tematu, którego wypowiedź dotyczy, kontekstu wypowiedzi, stosunku tego, kto mówi, do tego, o kim lub do kogo się mówi, także od intonacji, od towarzyszących gestów itd. J. Puzynina w tym samym wywiadzie podkreśla:

Zwłaszcza wartościowania dotyczace nazw ludzi, przedmiotów, zdarzeń, odbieramy bardzo różnie. Czasem to różne rozumienie słów w poszczególnych użyciach wiąże się $z$ bardzo ogólnym ich znaczeniem. Przykładem może tu być przymiotnik dobry. $Z$ bliska mi profesor Renatą Grzegorczykową inaczej rozumiemy słowo dobroć. Obie wywodzimy się $z$ warstwy inteligenckiej, obie należymy do środowiska akademickiego, A tymczasem dla mnie dobroć wiąże się $z$ postawa, tj. ze stosunkiem do innego człowieka, a także $z$ chęcia pomocy czynnej temu, kto tego potrzebuje. Nieodzowne jest to poczucie potrzeby pomocy, jeśli już nie jakieś czynne działanie. Natomiast profesor Grzegorczykowa uważa, że wystarczy, jeżeli umiemy sobie wyobrazić, na czym polega czyjeś nieszczęście; działanie, nawet chęć działania, nie sa konieczne. W naszej dyskusji, opisanej w jednym $z$ moich artykułów, ona kładzie duży nacisk właśnie na wyobraźnię i dalej warszawska językoznawczyni podkreśla: „Co ważne w tej całej sprawie braku jednorodności w rozumieniu słów? To że różnice dotyczą szczególnie często wyrazów (i wyrażeń) nacechowanych aksjologicznie. Uwidoczniają to przytoczone wyżej przykłady. Może to dotyczyć całych grup użytkowników języka. Proszę wziaćc pod uwagę, powiedzmy słowa uczciwy i uczciwość. Jedni uważaja, że mamy tu do czynienia $z$ bezwzględna zasada, że nie ma sytuacji, w której można być nieuczciwym, na przykład kraść. Sa jednak tacy, którzy nie uznaja za nieuczciwość tego, że ktoś głodny kradnie bułkę w piekarni. Ale znowu, co do tych usprawiedliwiających okoliczności zdania są bardzo podzielone. Mówi się o białym kłamstwie, na przykład, wobec kogoś śmiertelnie chorego, przed kim zatajamy jego stan. Sa jednak tacy, którzy kategorycznie negują białe kłamstwo, twierdzac, że przysporzenie cierpienia nieuleczalnie choremu jest mniejszym złem niż powiedzenie mu nieprawdy. Sa tacy lekarze, sa tacy księża [Puzynina 2016].

\section{SPOSÓB WPROWADZANIA INFORMACJI PRAGMATYCZNEJ W SLOWNIKU POPRAWNOŚCIOWYM}

Osobną kwestię natury metodologicznej stanowi sposób wprowadzania informacji pragmatycznej w słowniku poprawnościowym. Tradycyjnie do tego celu służą w hasłach słownikowych, także w słowniku ortoepicznym, szczegółowe kwalifikatory. Te pozwalają na kondensację opisu właściwości pragmatycznych. Czasem jednak zastosowania kwalifikatora nie można uznać za wystarczające pokazanie okoliczności, w jakich użycie jednostki języka ma takie, a nie inne konsekwencje komunikacyjne, np. obraża czy deprecjonuje. Wydaje się, że czasem, by słownik ortoepiczny rzeczywiście spełniał swoją funkcję, okoliczności takie winny być przedstawione w sposób bardziej opisowy, narracyjny, nie da się ich bowiem zamknąć tylko w systemie kwalifikatorów. 


\subsection{Kwalifikatory pragmatyczne}

Jako wystarczajace byłoby może zamykanie informacji pragmatycznej w stosownym kwalifikatorze, np. w odniesieniu do takich wyrazów niebezpiecznych w przestrzeni publicznej (niepoż.?), które w odczuciu wszystkich albo części użytkowników języka deprecjonują, dyskryminują ludzi ze względu na ich tożsamość: narodowość (por. pejsol, parch), rasę (np. ciapaty, banan, kokos, oreo 'o osobach czarnoskórych'), religię (np. katol), płeć (por. słaba płeć, kura domowa 'o kobietach'), orientację seksualna (np. homoś, pedał) itd. albo określaja negatywne cechy wyglądu, umysłu itp. człowieka, także jego poglądy w sposób może nawet i prawdziwy, ale nieprzyjemny (np. kurdupel, głupek, debil, palant, platfus 'członek Platformy Obywatelskiej', pisior 'zwolennik albo członek partii PIS', moher 'osoba starsza, zwłaszcza kobieta o konserwatywnych poglądach'), dotycza pewnych nieprzyjaznych sposobów mówienia o ludzkich ułomnościach, na które nie mają wpływu, np. o ich chorobach (por. kaleka, upośledzony umysłowo, niedorozwinięty, opóźniony $w$ rozwoju). Podobne wyrazy funkcjonuja często w mowie potocznej i przez fakt, że są nośnikami krzywdzących stereotypów nie służą kształtowaniu dobrych relacji między ludźmi, a więc nie sprzyjają dobrej, prowadzącej do porozumienia komunikacji językowej. Słownik ortoepiczny, mający za zadanie dostarczenie wzorców więcej niż tylko p o p ra w n e g o, a więc wła ś ciwe go zachowania językowego, i kodyfikujący normy obyczajowe w zakresie użycia języka, powinien dziś przestrzegać przed konsekwencjami komunikacyjnymi i społecznymi posługiwania się $\mathrm{w}$ sferze publicznej wyrażeniami odczuwanymi (choćby tylko przez część użytkowników) jako obraźliwe czy wzbudzające niechęć wobec jakiejś osoby (lub grupy osób) ze względu na jej tożsamość, w celu jej społecznego wykluczenia albo jako sygnał braku życzliwości wobec osób odmiennych „Z natury” lub „Z własnego wyboru” (słuchających odmiennej niż inni muzyki, ubierających się inaczej czy majacych nietypowe lub tylko inne niż mówiący poglądy).

\subsection{Artykuły narracyjne (opisowe) związane $z$ wybranymi leksemami - exemplum: pan / pani}

Sa jednak jednostki leksykalne, których właściwości pragmatyczne sa tak złożone, że ich omówienie w słowniku wymagałoby jednak bardziej rozbudowanego komentarza, a nie tylko opatrzenia ich kwalifikatorem pragmatycznym. Jako przykład takich jednostek i należnych im komentarzy mogłyby posłużyć jednostki pan / pani.

Zwróćmy uwagę, że właściwe posługiwanie się rzeczownikami pan / pani wymaga od użytkowników języka wielu kompetencji natury pragmatycznej. Ważna ich funkcją w polszczyźnie jest komunikowanie honoryfikatywnego nacechowania rzeczownika, obok którego wyrazy 
te występują. Rzeczownikiem takim może być nazwa antroponimiczna (imię - w formie pełnej lub zdrobniałej, nazwisko, imię połaczone $z$ nazwiskiem) czy też rzeczownik tytularny (np. doktor, profesor, prokurator, prezydent).

Struktury „pan / pani + nazwa antroponimiczna lub rzeczownik tytularny" użyte nie w sposób adresatywny (tzn. nie podczas zwracania się do danej osoby), lecz referujący, narracyjny (gdy mówimy o kimś trzecim) maja zasięg ograniczony do pewnych okoliczności, stosowane sa np. $\mathrm{w}$ adresowaniu korespondencji czy podczas publicznej prezentacji nazwisk $z$ listy [por. Huszcza 2006, 113]. W innych okolicznościach w tekstach ściśle narracyjnych, jeżeli między nadawca a osobowym obiektem narracji nie zachodzi społeczna relacja jakiejś bliższej znajomości, nie poprzedza się rzeczowników tytularnych lub antroponimicznych wyrazem pan / pani [por. Huszcza 2006, 110-115; Łaziński 2006, 15]. Połączenie takie (pan prezydent, pan profesor) nadaje się tylko na okoliczności bardzo uroczyste, a także w sytuacjach, w których przemawiamy w obecności tych osób (prezydenta, profesora) i chcemy okazać im szczególny szacunek.

W miejscu pracy - w relacjach oficjalnych formuła wyrażajacca szacunek jest połączenie „pan / pani plus nazwa stanowiska lub stopień naukowy", np.: panie profesorze, pani dyrektor, panie kierowniku, pani prezes. Zwykle jednak pomija się tę część tytułu zawodowego, który obniża rangę rozmówcy. Do zastępcy dyrektora zwracamy się zatem panie dyrektorze, a do wiceministra - panie ministrze. Także o osobach, a zwłaszcza do osób, które w przeszłości pełniły ważne funkcje państwowe (np. funkcje premiera, prezydenta), zwyczajowo mówimy panie premierze (premier Mazowiecki), panie prezydencie (prezydent Kwaśniewski).

W niektórych środowiskach zawodowych, np. akademickim czy lekarskim, żywy jest w formułach adresatywnych zwyczaj skracania dystansu przez redukcje form typu panie profesorze, panie doktorze - do członu profesorze, doktorze (dotyczy to jednak wyłącznie zwracania się do mężczyzn).

Jednostki leksykalne pan / pani silnie kojarzone sa $z$ podstawowym celem grzeczności językowej, czyli wyrażaniem szacunku wobec drugiej osoby. W sytuacji „referującej” moga one jednak być oznaka złamania zasad etykiety - znakiem lekceważenia, a czasem - ironii [por. Łaziński 2006, 84]. I tak np., gdy mówi się o osobie znanej, poprzedzając jej nazwisko lub imię wyrazem pan / pani (np. pan Duda, pan Wałęsa, pan Stefan zamiast Stefan Niesiołowski) - podobny zabieg służy deprecjacji tej osoby. Lekceważenie, wyrażanie dystansu, ironii lub nawet poniżanie osób znanych za pomoca dodawania do antroponimów wyrazów pan / pani spotykane jest przede wszystkim w dyskursie publicznym, medialnym. Podobnie jest w wypadku „referujących” użyć rzeczowników pan / pani przed nazwiskiem takiego znanego polityka lub artysty, któremu tytuł nie przysługuje (np. pani Pawłowicz, pani Żmuda-Trzebiatowska), 
także twórcy jakiegoś znanego dzieła literackiego, malarskiego, filmowego itp. (np. obrazy pana Matejki, filmy pana Wajdy, wiersze pani Szymborskiej) lub w sytuacji, gdy rzeczowniki pan / pani sa użyte zamiast adekwatnych wobec osób duchownych rzeczowników ksiądz czy siostra. Jako lekceważące odczuwane jest również dodanie wyrazu pan / pani do nazwiska lub imienia autora tekstu w polemicznych wobec niego recenzjach [por. Łaziński 2006, 89-90], np. rozprawa pani Kowalskiej.

Rzeczowniki pan / pani łączą się z czasownikiem w 3. osobie 1. pojedynczej. Odstępstwa od tej reguły - np. Gdzie sie pan pchasz? - nie mieszczą się regułach grzeczności językowej.

Formuły ten pan / ta pani mogą być używane w prywatnej rozmowie, np. do dziecka: Nie mów tak, bo sprawisz tej pa ni przykrość. Mówienie jednak w taki sposób o kimś publicznie jest oznaka braku szacunku (por. wypowiedź ministra Ziobry o znanym profesorze medycyny: Już nikt nigdy przez tego pana życia pozbawiony nie będzie, posłanki Pawłowicz o innej posłance: ta pani).

Zwracanie się w relacjach prywatnych i zawodowych za pomoca formy panie lub pani poprzedzającej tylko nazwisko (np. panie Kowalski, pani Kowalska) zwykle nie jest przez użytkowników dobrze widziane, choć jest akceptowalne w środowiskach małych miejscowości, gdzie wszyscy się znaja.

W młodszym pokoleniu użytkowników języka upowszechnia się łączenie rzeczowników pan / pani z imionami (także zdrobniałymi): pani Ania, pan Wojtek, nawet w bezpośrednich zwrotach, i to do osób starszych i hierarchicznie wyższych lub nawet w kontakcie oficjalnym (pani Aniu, panie Wojtku), co więcej - bez obustronnego uzgodnienia (np. zwraca się tak student w korespondencji mejlowej do nauczyciela akademickiego). Taki sposób zwracania się przez krzewicieli stosunkowo nowego zwyczaju odczuwany jest przez jego zwolenników jako pozytywna oznaka sympatii. Coraz częściej omawiana formuła staje się także częścia „grzeczności handlowej". Zwracaja się tak do klientów pracownicy banków, agenci ubezpieczeniowi czy akwizytorzy. W tych okolicznościach funkcja pragmatyczna takiej formuly jest spersonalizowanie i ocieplenie kontaktu. Dla użytkowników przywiązanych do tradycji taka forma jest odczuwana jako poufała, akceptowana więc tylko wobec kogoś, z kim łączą nas rzeczywiście bliskie stosunki towarzyskie (nie na tyle jednak symetryczne, byśmy mogli „przejść na ty”), a nie w rozmowie $z$ osoba stojąca w hierarchii wyżej, np. $z$ przełożonym lub $z$ osobą znacznie starszą. Wśród tych użytkowników języka omawiana forma preferowana jest tylko w osobowych relacjach symetrycznych - stosowana przez obie strony interakcji i za zgodą obu rozmówców. Może być ewentualnie stosowana przez jednego $z$ nich, ale tylko starszego lub wyższego ranga w hierarchii społecznej czy zawodowej wobec osoby młodszej lub zajmujaccej niższą pozycję hierarchiczna - forma wyraża wtedy życzliwość i sympatię, ale również może stanowić sygnał asymetrii statusu partnerów. Dlatego dobrze w po- 
dobnych okolicznościach posługiwać się taka forma $z$ wyczuciem, by jedna ze stron interakcji nie czuła się dyskryminowana ze względu na wiek czy status. To bowiem, co w naszej intencji miało być sygnałem sympatii, może zostać zinterpretowane jako protekcjonalizm, traktowanie rozmówcy $z$ wyższością.

W sytuacjach codziennych ze słowami pan / pani Polacy używają czasem nazwy zawodu jako tytułu (np. panie kierowco, panie dozorco). Zwyczaj ten, choć powszechny, nie przez wszystkich użytkowników języka jest akceptowany. Podkreślanie w ten sposób niskiej funkcji zawodowej rozmówcy nie jest odbierane jako taktowne.

W warunkach pisemnej komunikacji oficjalnej (w mejlach, ankietach, ulotkach), gdy nie znamy płci odbiorcy, możemy zastosować 4 konwencje adresatywne, każda ma jednak swoje ograniczenia:

- zastosować ukośnik Pan / Pani;

- formę adresatywna żeńska lub jej fleksyjny wykładnik podać w nawiasie: Pan (Pani) lub Pan(i);

- użyć adresatywu Państwo;

- użyć form czasownikowych 2. os. 1. poj. łączących się zwykle z zaimkami ty, twój.

Wielość ukośników lub nawiasów w tekście nie jest wygodna (ekonomiczna) i nie wygląda najlepiej, por.: Szanowny Panie (Szanowna Pani), przesyłam Panu (Pani) nasza oferte sprzedaży zestawów fotowoltaicznych. Jeśli zainteresował Pana (Pania) prad ze słońca, doradzimy Panu (Pani) w wyborze urzadzeń i miejsca montażu.

Rozwiąanie nawiasowo-ukośnikowe ma również inny mankament - nie pozwala uwolnić się od „uwikłania w płeć” (a tę w interesującym nas kontekście chcielibyśmy właśnie „obejść”), ponadto kolejność wyrazów (najpierw forma pan, później pani) może być przez niektórych użytkowników języka (np. środowiska feministyczne) postrzegana jako dyskryminujaca kobiety. Pewnym rozwiązaniem jest zatem w takiej sytuacji zastosowanie formy Państwo, która - choć zasadniczo odnosi się do kilku osób obojga płci (przynajmniej dwojga) - w sytuacji odbioru konkretnej wypowiedzi może jednak odnosić się do adresata jednostkowego: Szanowni Państwo, przesyłam nasza oferte sprzedaży zestawów fotowoltaicznych. Jeśli zainteresował Państwa prad ze słońca, doradzimy Państwu $w$ wyborze urzadzeń $i$ miejsca montażu, a także wykonamy kalkulacje kosztów instalacji.

W niektórych okolicznościach (np. w przepisach kulinarnych, poleceniach i pytaniach egzaminacyjnych, podręcznikowych i ankietowych czy w ulotkach informacyjnych) bardziej naturalna będzie forma ty połączona $z$ 2. osoba czasownika lub (czasami) - bezosobowa, np.: Rozpuść sól $w$ szklance wody (Proszę rozpuścić sól $w$ szklance wody), W podanym zdaniu znajdź 3 rzeczowniki ( $W$ podanym zdaniu prosze znaleźć 3 rzeczowniki), lle godzin dziennie poświęcasz na przegladanie Internetu? Pewną ostrożność trzeba zachować, zastępując formę pan / pani formą 
ty w pisanych tekstach ofert (np. handlowych czy bankowych). Zmniejszenie za jej pomoca dystansu, kształtowanie bardziej partnerskiej relacji nie zawsze jest akceptowane przez starszych użytkowników języka.

Forma adresatywna pośrednią między pan / pani a ty sa połaczenie imienia - świadczacego o relacji na ty - ze zdaniem, w którym relacja między nadawca a odbiorca określona jest na pan / pani (np. Joasiu, czy może Pani podać nam przykład). Takie połaczenia maja charakter protekcjonalny albo służą skróceniu dystansu. Tak zwykle mówi ktoś wyższy ranga (np. wiekiem lub stanowiskiem) do kogoś młodego, np. profesor uczelni do studenta. W takich okolicznościach spotyka się to na ogół $z$ aprobatą.

\subsection{Artykuły opisowe związane $z$ kategoriami wyrazów (exempla: wyrazy dziecięce, metaforyczne nazwy osób)}

Wydaje się, że pragmatyczny aspekt normy językowej może być ujmowany w słowniku właściwych użyć języka nie tylko w „zakładkach pragmatycznych" haseł szczegółowych, ale także zostać ujęty kompleksowo jako hasło „teoretyczne” odnoszace się albo do właściwości pragmatycznych pewnych kategorii słów (jak np. deminutiwa, słownictwo dziecięce, metafory odnoszace się do osób).

Przyjrzyjmy się pod tym katem na przykład tzw. wyrazom dziecięcym. Wyrazy dziecięce to słowa w rodzaju: am, lulu, hajty, ała, myju, mniam, mniam, kaku itp. Składaja się one na tzw. język nianiek - język zwłaszcza kobiet, w mniejszym stopniu - mężczyzn, służący dorosłym budowaniu więzi z dzieckiem za pomoca słowa. Słownictwo tego rodzaju stanowi część rejestru leksyki ekspresywnej w ramach języka familijnego, ten zaś należy do stylu potocznego. Zdarza się wszakże, że niektóre wyrazy języka nianiek używane sa także między dorosłymi użytkownikami języka, jednak tylko w sytuacji nieoficjalnej i gdy rozmówców łączą bardzo bliskie więzi (np. słowo siusiu). Posługiwanie się nimi w sytuacji oficjalnej i wobec osób obcych, starszych (wiekowych), np. w domach seniorów lub wobec osób publicznie znanych, ma charakter deprecjatywny, ośmieszajacy, nie jest grzeczne. Jako taka może być zinterpretowana wypowiedź posłanki podczas posiedzenia parlamentu do innych posłów: tak smakuje opozycja, m n ia $m, m$ n ia $m$. Trzeba to jasno podkreślić, że posługiwanie się wyrazami dziecięcymi w sytuacji oficjalnej i wobec osób publicznych lub w odniesieniu do nich ma funkcję ośmieszająca, deprecjatywna, a nawet obraźliwą, o czym świadczy fragment pamiętnego felietonu $z$ tygodnika „Nie”, w którym autor o Janie Pawle II pisał, zwracajacc się do niego bezpośrednio:

Kochany staruszku! Połóż się do łóżka. Przykryj kołderką. Poczytaj sobie Katarzynę Grocholę albo jakiś lekki kryminał. Poćpaj kawiorku, pocmoktaj melbę, m n i a m, m n i a m. Puść se na wideo „Dzień świra” - uśmiejesz się zacnie. Podłub sobie w nosie 
albo między palcami u nóg, co tam lubisz. Trochę drzemki, potem kak u [J. Urban, Obwoźne sado-maso, „Nie” nr 33/2002].

Za inny przykład kategorii słów, które mogłyby zasługiwać na kompleksowy opis pragmatyczny w kontekście słownika użyć właściwych niech posłuża metafory nazywające osoby. Opisując innych ludzi ze względu na ich wygląd, cechy charakteru, poglądy itp., by oddać je w sposób bardziej obrazowy, korzystamy $z$ metafor, zarówno tych konwencjonalnych, utrwalonych w przenośnych znaczeniach wyrazów (np. mrówka - 'o kimś pracowitym'), jak i tworzonych indywidualne, innowacyjnie (np. bulterierka PIS-u).

Duża grupa metafor obu typów ma charakter deprecjonujący, a nawet obraźliwy. Należą do nich na przykład takie utrwalone w języku przenośnie, które oparte sa na rzeczownikach w znaczeniach dosłownych odnoszacych się do zwierząt niższego rzędu, zwłaszcza mięczaków, płazów, gadów, robaków, ryb itp.: truteń, gnida, menda, pijawka, rekin, płotka, ropucha, żmija, mięczak, wą̇̇, kameleon. Ogólnie posługiwanie się przenośnymi nazwami zwierząt w odniesieniu do ludzi wymaga wielkiej ostrożności, duża część $z$ nich ufundowana jest na negatywnych stereotypach, jakie przypisujemy w naszej kulturze wielu zwierzętom (np. głupotę - gęsi, złośliwość - małpie, hienie - agresywność) itp. Stąd posługiwanie się w odniesieniu do ludzi rzeczownikami gęś, małpa, hiena itp. może być odbierane jak inwektywa skierowana wobec tych osób. Podobnie funkcję deprecjatywna spełniają rzeczowniki pierwotnie odnoszące się do części ciała zwierząt (np. pysk, morda, łapa, kopyto) lub czynności przez nie wykonywanych albo też stanów, którym podlegaja, np. zdychać, żreć. Wszystkie wymienione i podobne im słowa, gdy używamy ich w odniesieniu do człowieka, deprecjonuja jego godność przez swego rodzaju animalizację (nadanie człowiekowi cech zwierzęcych).

Sytuacja jest analogiczna, jeśli sięgamy po metafory tworzone okazjonalnie, ale $z$ wykorzystaniem mechanizmu, o którym była mowa, por.: On jest $z$ pierwszego zawodu entomologiem, profesorem owadologii $i$ jego naturalne środowisko ekologiczne to wszy, mendy, gnidy, pluskwy, muchy plujki, żuki gnojniki i to jest również jego elekto rat. I to świadczy o potędze polskiej demokracji, nawet wszy, mendy maja swoja reprezentacje [J. Pietrzak, koncert 21 marca 2016 r.].

$Z$ kolei nazwy przedmiotów użyte metaforycznie do nazwania człowieka, por.: traba, cymbat, drewniak, młotek, moher, dzban itp., w jakimś stopniu reifikuja go (uprzedmiotawiaja) i dlatego sa przez użytkowników języka także odbierane jako deprecjonujące tak nazywane osoby.

Do metafor ludzkich niepożądanych w dialogu, w którym zależy nam na porozumieniu w klimacie szacunku, należą również przenośnie oparte na nazwach zawodów w naszej tradycji kulturowej nisko cenionych, takich jak: zawody ośmieszające (np. kuglarz, komik, komediant, magik, klaun), polegajace na przesadnym dozorowaniu (np. ekonom, żandarm, 
kapral, zomo) czy związane $z$ pozbawianiem życia ludzi lub zwierzat (np. hycel, rzeźnik, kat, oprawca).

\section{Bibliografia}

J.D. Apresjan, 1974, Leksicheskaia semantika. Sinonimicheskie sredstva iazyka, Moskwa; tłum. pol. Z. Kozłowska, A. Markowski, 2000, Semantyka leksykalna. Synonimiczne środki języka, Warszawa.

J.D. Apresjan, 1988, Informacja pragmatyczna $w$ słowniku jednojęzycznym [w:] Z. Zaron (red.), 2012, Z warsztatu leksykografa, Warszawa, s. 41-63; pierwodruk w: Прагматика и проблемы интенсиональности, Moskwa, s. 7-44.

M. Bańko, 2008, O normie i błędzie, „Poradnik Językowy” z. 5, s. 3-17.

A. Bogusławski, 1973, Właściwości pragmatyczne wyrażeń równoznacznych. Projekt schematu, „Pamiętnik Literacki” z. 3, s. 121-151.

A. Bogusławski, M. Danielewiczowa, 2005, Verba polona abscondita. Sonda słownikowa III, Warszawa.

A. Bogusławski, T. Garnysz-Kozłowska, 1979, Addendum to Polish phraseology. Introductory issue. Addenda do polskiej frazeologii. Zeszyt wstęny, Edmonton.

A. Bogusławski, J. Wawrzyńczyk, 1993, Polszczyzna, jaka znamy. Nowa sonda słownikowa, Warszawa.

W. Doroszewski (red.), 1976, Słownik poprawnej polszczyzny, Warszawa.

G. Gazdar, 1979, Pragmatics: Implicature, Presupposition, and Logical Form, New York.

R. Huszcza, 2006, Honoryfikatywność-gramatyka, pragmatyka, typologia, Warszawa.

R. Kalisz, 1993, Pragmatyka językowa, Gdańsk.

M. Łaziński, 2006, O panach i paniach. Polskie rzeczowniki tytularne i ich asymetria rodzajowo-płciowa, Warszawa.

A. Markowski (red.), 2018, Wielki słownik poprawnej polszczyzny, Warszawa.

A. Markowski, J. Puzynina, 1993, Kultura języka [w:] J. Bartmiński (red.), Wspótczesny język polski, Wrocław, s. 53-72.

R. Montague, (1968) 1974, Pragmatics [w:] R.H. Thomason (red.), Formal Philosophy. Selected Papers of Richard Montague, New Haven, s. 95-118.

Ch. Morris, 1938, Foundations of the theory of sings [w:] O. Neurath, R. Carnap, Ch. Morris (red.), International Encyclopaedia of United Science I, Chicago, s. 1-59.

J. Puzynina, 2014, Kłopoty z nazwami wartości (i wartościami), „Etnolingwistyka" nr 26, s. 7-20.

J. Puzynina, 2016, Zawsze rozmawiać, https://teologiapolityczna.pl/zawszerozmawiac-przeczytaj-wywiad-z-prof-jadwiga-puzynina [dostęp: 12.12.2019].

P. Stalmaszczyk, 2008, Semantyka formalna i pragmatyka: przeglad wybranych definicji, „Biuletyn Polskiego Towarzystwa Językoznawczego” LXIV, s. 9-24.

R.C. Stalnaker, 1970, Pragmatics, „Synthese” 22, s. 272-289.

R.C. Stalnaker, 1972, Pragmatics [w:] G. Harman, D. Davidson (red.), Semantics of Natural Language, Dordrecht, s. 380-397.

S. Szober, 1937, Słownik ortoepiczny: jak mówić i pisać po polsku, Warszawa.

S. Szober, 1948, Słownik poprawnej polszczyzny, Warszawa. 


\section{Pragmatic information in an orthoepic dictionary. Current state and needs}

\section{Summary}

For language users, language is a certain continuum along which the boundary between semantics and pragmatics blurs and where phenomena from both planes are related to the concept of language norm (linguistic standard, literary norm) and the proper use of linguistic units is not limited to complying with the rules of grammar or respecting their strict meaning. An important component of the proper use of language is the pragmatically adequate selection of the available language means. The question of a methodological nature is the way in which pragmatic information is introduced to such lexicons. Traditionally, usage labels are used for this purpose. Sometimes, however, in order for an orthoepic dictionary to really fulfil its function, pragmatic information should be presented in a more descriptive, narrative manner. The pragmatic aspect of the language norm can be described in a dictionary not only in the "pragmatic tabs" of specific entries but it can also be captured comprehensively, as a "theoretical article" relating either to the pragmatic properties of certain word categories (e.g. diminutives, children's vocabulary, metaphors relating to people).

Keywords: pragmatics - orthoepic dictionary - language norm - correctness.

Adj. Monika Czarnecka 


\section{O B J A Ś N I E N I W Y RAZ Ó W I Z W R O T Ó W}

Magdalena Smolen-Wawrzusiszyn

DOI: $10.33896 /$ PorJ.2021.4.6

(Katolicki Uniwersytet Lubelski Jana Pawła II,

e-mail: lumina@kul.lublin.pl)

ORCID: 0000-0002-7886-5894

\section{CZY GRUPA MOŻE BYĆ ŚREDNIOWALNA? GEOS W SPORZE O NOWY TERMIN W MATEMATYCE}

\section{WSTEPP}

Przedmiotem rozważań w niniejszym artykule jest funkcjonujący od co najmniej dekady w żargonie matematycznym termin grupa średniowalna. Został on zaproponowany jako krótszy wariant czteroelementowej nazwy grupa dopuszczajaca średnia niezmiennicza, będącej polskim ekwiwalentem angielskojęzycznej frazy amenable group.

Asumptem do podjęcia tego tematu była prośba jednego $z$ przedstawicieli środowiska matematyków o ocenę normatywną neologizmu średniowalny, który stał się obiektem sporu i dość emocjonalnej wymiany poglądów. ${ }^{1}$ Celem niniejszego artykułu jest analiza zagadnienia $z$ perspektywy lingwistycznej oraz uzasadnienie argumentów przedstawionych matematykom do rozważenia w spornej dla nich kwestii. W szerszej perspektywie badawczej podjęty problem stanowi studium przypadku z zakresu dyskutowanej w lingwistyce normatywnej problematyki, jaka jest status zapożyczeń (zwłaszcza angielskich) w polszczyźnie, w szczególności zaś - status terminów obcojęzycznych w polskich językach specjalistycznych. ${ }^{2}$

W prezentowanej tu interpretacji normatywnej neologizmu średniowalny oraz jego fakultatywnych zamienników zostały uwzględnione następujace elementy składowe: 1) wykładnia formalna - zasady słowotwórstwa polskiego w odniesieniu do tworzenia formacji przymiotnikowych, 2) kryteria poprawności tworzenia terminów specjalistycznych, 3) wykładnia matematyczna - precyzja znaczeniowa i funkcjonalność proponowanych wariantów terminologicznych oraz ich (ewentualna) akceptacja wśród użytkowników dyskursu matematycznego.

1 Sytuacja ta została przedstawiona w artykule Czy matematycy sa „amenable”? przyjętym do druku w „Wiadomościach Matematycznych” 56 (2), 2020 [w druku].

2 Por. np. Dunaj, Mycawka 2017; Kolasa 2014; Naruszewicz-Duchlińska 2016; Witalisz 2019. 


\section{2. ŹRÓDLO TERMINU I JEGO PERCEPCJA W DYSKURSIE MATEMATYCZNYM}

Jak już wspomniano, termin grupa średniowalna pojawił się w dyskursie matematycznym jako polski odpowiednik angielskojęzycznej nazwy amenable group. Kwerenda internetowa wykazała, że w środowisku matematyków problem $z$ adaptacją tej nazwy w polszczyźnie zauważono już niemal dekadę temu. W sierpniu 2011 r. na forum strony matematyka.pl zamieszczono następujące pytanie: ${ }^{3}$

(1) Jaka jest polska nazwa dla amenable grup?, (...) tj. grupy lokalnie zwartej, która dopuszcza istnienie pewnej średniej prawostronnie (równoważnie, lewostronnie) niezmienniczej na $\mathrm{L} \infty(\mathrm{G})$ (w sensie miary Haara) (...) Czy jest jakieś polskie przyjęte tłumaczenie słowa amenable w kontekście grup i algebr Banacha?4

W postach do tego wątku pojawiły się następujące odpowiedzi: ${ }^{5}$

(2) U nas na analizie funkcjonalnej profesor (...) tłumaczył to pojęcie jako „grupa średniowalna”. W paru innych miejscach też widziałem takie tłumaczenie, więc przypuszczalnie jest to przyjęta forma.

(3) Pojęcie w google pojawia się rzeczywiście, ale tylko u niego (...) To słowo po polsku brzmi jednak nieco... średniowalnie.

(4) Cóż, jest to zapewne jedno $z$ tych pojęć, których zazwyczaj nie tłumaczy się na polski, bo wszyscy wiedzą o co chodzi (po angielsku), a jest wystarczająco zaawansowane, by w zasadzie nie występowało w literaturze polskojęzycznej. Podobnie, jak $\mathrm{np}$. pojęcie filtr generyczny (teoria forcingu) w zasadzie nie występuje w naturze, bo wszyscy (?) mówia „dżenerik” (czyli generic).

(5) W środowisku matematyków zajmujących się równaniami funkcyjnymi termin amenable group zwykło się tłumaczyć jako grupa dopuszczająca średnia niezmienniczą. Słowo średniowalny brzmi rzeczywiście, mówiąc oględnie, średnio.

Ta raczej skromna - jeśli chodzi o liczbę uczestników ${ }^{6}$ - ale znacząca dla sprawy dyskusja ujawniła współistnienie trzech stanowisk wśród specjalistów odnośnie do traktowania angielskiego terminu: 1) pozostawienie go w oryginalnej, angielskiej wersji językowej; 2) tłumaczenie w postaci wyrażenia grupa średniowalna; 3) tłumaczenie o charakterze omownym 'grupa dopuszczająca średnia niezmienniczą'. W cytowanych wypowiedziach pojawiły się też elementy oceny i argumentacji normatywnej wobec wskazywanych rozwiązan. Przyjęcie terminu grupa śre-

3 https: / / matematyka.pl/viewtopic.php?t=260623 [dostęp: 25.07.2020].

4 Cytowane fragmenty, które stanowią egzemplifikację analizowanego zagadnienia, sa oznaczane w tekście ciagła numeracja poprzedzajaca prezentowany materiał źródłowy.

5 Wszystkie cytaty pochodzą $z$ wyżej wskazanej strony i sa podane w wersji oryginalnej, bez żadnych zmian językowo-stylistycznych i redakcyjnych.

${ }^{6}$ Informacje pozyskane od dyskutantów zaangażowanych w omawianą kwestię potwierdzaja na razie niewielka liczebność środowiska polskich matematyków zajmujacych się zagadnieniem amenable group. 
dniowalna jest uzasadniane kryterium uzualnym, czyli potwierdzeniem występowania takiego tłumaczenia w wypowiedziach / zapisach innych matematyków. Pozostawienie angielskojęzycznej wersji terminu jest argumentowane również odwołaniem do pewnego uzusu w dyskursach specjalistycznych, w których zdarza się, że istnieje konieczność akceptacji formy obcojęzycznej $z$ uwagi na jej nieprzetłumaczalność na język polski (zazwyczaj sa to sytuacje wymagające wieloelementowego odpowiednika w polszczyźnie - niewygodnego w komunikacji - dla dużo krótszej formy wyjściowej). W dwóch wypowiedziach formacja średniowalny została oceniona negatywnie ze względów estetycznych (brzmieniowych).

Po raz kolejny watek amenable group został podjęty w Internecie we wrześniu 2015 r. przez autora bloga zatytułowanego Być matematykiem. Problem $z$ adaptacja amenable group na polskim gruncie przywołano tu w dyskusji nad innym terminem specjalistycznym (zwarta grupa) i w odniesieniu do interesującego nas terminu zamieszczono następujące wypowiedzi: ${ }^{7}$

(6) Czasem nie ma jeszcze polskich odpowiedników wprowadzonych pojęć. Myślę np. o amenable group. Od biedy można powiedzieć grupa dopuszczająca średnią niezmiennicza, co jest zbyt długie jak na nazwę pojęcia. A poza tym, co tu dopuszczać? To słowo weszło do żargonu matematycznego. Jest jeden dopust... Boży.

(7) Widzę, że była już na ten temat krótka dyskusja na matematyka.pl, ale nie mogę się powstrzymać przed małym protestem. Odpowiednik (grupa średniowalna) istnieje i jest używany, choć nie mogę wykluczyć, że jedynie w Warszawie. Nawet zapominając na chwilę o relacji Warszawa vs. Reszta Świata, jestem ogólnym zwolennikiem wprowadzania polskich odpowiedników. Osobiście istnienie takowych odbieram zawsze jako świadectwo dbałości autora o język polski (i jego rozwój) oraz dojrzałości dziedziny (jeśli jakieś pojęcie zostało przetłumaczone, to widocznie okazało się owocne).

(8) Dziękuję za zwrócenie uwagi na tę nazwę. Przy wprowadzaniu polskich odpowiedników angielskich nazw pojęć należy moim zdaniem zachować rozsądek i iść na jakiś kompromis. Wszystkiego nie spolszczać. Osobiście neologizm średniowalna nie podoba mi się, ale to kwestia gustu. Czy spolszcza się słowo computer do np. rachmistrz? Nie, w ususie językowym jest tylko inna pisownia. Ale np. Czesi maja počitač, zaś Francuzi ordinateur.

Kolejna dyskusja, która przetoczyła się wśród matematyków, miała już miejsce w przestrzeni realnej, a została sprowokowana użyciem jednego $z$ wyżej wskazanych tłumaczeń amenable group w rozprawie doktorskiej. Jednym $z$ głosów w tej dyskusji - z perspektywy językoznawczej - sa przedstawione rozważania.

7 Wszystkie cytaty pochodza ze strony https://byc-matematykiem.pl/ zwarta-grupa/ [dostęp: 25.07.2020]. 


\section{DYSKUSJA}

\subsection{Wykładnia formalna}

Jak podaja opracowania $z$ zakresu słowotwórstwa polskiego, formant -alny jest wykładnikiem słowotwórczym dwóch kategorii przymiotników: 1) odrzeczownikowych, np. medialny, multiregionalny) oraz 2) odczasownikowych, np. definiowalny, sterowalny, przy czym - zdaniem H. Jadackiej - „połączenia $z$ tematami werbalnymi wydaja się częstsze i naturalniejsze" [Jadacka 2001, 102]. Przymiotniki tworzone od czasowników to $\mathrm{w}$ większości tzw. czasowniki o znaczeniu potencjalnym, ${ }^{8}$ czyli takie, które wyrażają możliwość / niemożliwość wykonania / działania / podlegania itp., np.: ${ }^{9}$

definiowalny 'taki, który można zdefiniować'

porównywalny 'taki, który można porównać'

niepoliczalny 'taki, którego nie można policzyć'

nierozpuszczalny 'taki, którego nie można rozpuścić'

Analizy prowadzone przez L. Ptak wykazały dodatkowo, że

współczesny język polski wykazuje pewna tendencję do tworzenia przymiotników potencjalnych $z$ formantem -alny od czasowników obcych, zwłaszcza w przekładach tekstów z dziedzin nauki, terminologii specjalistycznej [Ptak 2009, 96].

Jeśli chodzi o przymiotniki $z$ formantem -alny tworzone od rzeczowników, to mają one znaczenie 'dotyczący czegoś, związany z czymś'; sa dużo rzadsze od formacji odczasownikowych i w większości należą do słownictwa dziedzinowego, np.: ${ }^{10}$

medialny 'związany $z$ mediami'

mitochondrialny 'zwiazany $z$ funkcjonowaniem lub budowa mitochondrium'

hegemonialny 'związany $z$ dominacją uzyskaną dzięki przewadze lub władzy nad innymi'

Warto jeszcze dodać, iż zdaniem niektórych badaczy

formant -alny doskonale nadaje się do tłumaczenia analogicznych formacji obcych $z$ formantami pochodzacymi od łac. -abilis (ang. -able) [Kurkowska 1953, 53].

Badania H. Jadackiej wskazują też na wzrastająca produktywność przyrostka -alny po 1989 r. w stosunku do badanych przez nia formacji przymiotnikowych z lat 1945-1964. We współczesnej polszczyźnie ten-

8 Na temat przymiotników $z$ formantem -alny o znaczeniu innym niż potencjalne zob. L. Ptak 2009, 87-90.

9 Eksplikację znaczeń podaję za: Wielki słownik języka polskiego [online] [dostęp: 25.07.2020].

$10 \mathrm{Jw}$. 
dencja do tworzenia formacji z tym sufiksem nadal wzrasta, zwłaszcza w obszarze komunikacji specjalistycznej, gdzie istotny wpływ na wybory językowe mają dwie tendencje charakterystyczne dla współczesnych innowacji jezzykowych: 1) tendencja do precyzji informacji, 2) tendencja do skrótu (ekonomizacji wypowiedzi).

\subsection{Kryteria poprawności terminów}

Dyskutowany w artykule neologizm średniowalny, jako formacja należaca do terminologii nauk matematycznych, wymaga również weryfikacji uwzględniającej kryteria poprawności terminów specjalistycznych. Jak bowiem wyjaśniono we wpisie na stronie Rady Języka Polskiego,

kodyfikacji terminów dokonują odpowiednie gremia, ustalające terminologię danej dziedziny życia. Kodyfikacja w języku ogólnym dokonuje się poprzez umieszczenie danego wyrazu w słowniku języka ogólnego. Jeśli wyrazy [z zakresu leksyki specjalistycznej-M. S.-W.], występują w tekstach z odpowiedniej dziedziny, to znaczy, że sa w uzusie danej grupy zawodowej jako profesjonalizmy. Jeśli mają swe definicje i są opublikowane w jakimś spisie terminologii - sa terminami. ${ }^{11}$

W haśle problemowym Terminologia znajdujacym się w Wielkim słowniku poprawnej polszczyzny PWN zostały wymienione następujące kryteria, najczęściej uwzględniane w ocenie nowych terminów:

1) zasada funkcjonalności, czyli kryterium właściwego wypełniania luk w nazewnictwie;

2) zasada logiczności - „składniki poszczególnych systemów terminologicznych powinny samym swoim brzmieniem nasuwać trafne skojarzenia $z$ odnoszacymi się do nich terminami";

3) zasada systemowości, „która wymaga, aby termin właściwie wyznaczał (poprzez formę i znaczenie) swoje miejsce w całym systemie słownictwa specjalnego, a tym samym i miejsce nazywanego pojęcia w systemie pojęć danej dziedziny";

4) zasada reproduktywności, „zgodnie $z$ która każdy nowy termin powinien mieć budowę umożliwiajaca tworzenie nazw pochodnych";

5) zasada ekonomiczności, „zgodnie $z$ którą termin powinien być możliwie krótki (nie - wielowyrazowy), łatwy do wymawiania i zawierać tylko te informacje, które sa potrzebne do identyfikacji desygnatu";

6) zasada poprawności, „postulująca zgodność terminu $z$ ogólnojęzykowa i profesjonalna normą językowa" [s. 1681-1686].

11 http://www.rjp.pan.pl/index.php?option=com_content\&view=article\&id= 996:kodyfikacja-terminow\&catid=44\&Itemid=208 [dostęp: 27.07.2020]. 
Z kolei A. Witalisz, analizując przydatność kryteriów poprawności językowej do oceny anglicyzmów profesjolektalnych, zwróciła uwage na to, iż

w ocenie języka odmian zawodowych należy pamiętać, że poszczególne kryteria moga odpowiadać potrzebom różnych użytkowników języka oraz że muszą być zastosowane w odniesieniu do konkretnej potrzeby komunikacyjnej, a nie odgórnie i dla wszystkich [Witalisz 2019, 52].

\subsection{Interpretacja ${ }^{12}$}

Jak przedstawione dane i ustalenia teoretyczne odnoszą się do interesujaccego nas przypadku? Cytując przywołana wyżej w internetowej argumentacji definicję amenable group, warto przypomnieć, że

jest to grupa lokalnie zwarta, która dopuszcza istnienie pewnej średniej prawostronnie (równoważnie, lewostronnie) niezmienniczej na $L \infty(\mathrm{G})$ (w sensie miary Haara). ${ }^{13}$

$Z$ definicji wynika więc, że formalnie i merytorycznie punktem odniesienia do polskiego terminu jest rzeczownik średnia. W zwiazku $z$ tym poprawna formacja przymiotnikowa o znaczeniu potencjalnym utworzona od takiej podstawy byłby leksem średnialny, który znaczyłby 'zwiąany ze średnią, dotyczący średniej'. Jednak, zdaniem matematyków, formację tę trudno zaakceptować, ponieważ jej struktura nie podpowiada jednoznacznie, ani nawet w przybliżeniu, faktycznego znaczenia w odniesieniu do funkcji w statystyce. O ile w wypadku grupy średnialnej matematycy maja watpliwości co do tego, czy dobrze oddaje zamierzony sens, o tyle neologizm średniowalny jest formalnie niepoprawny. Aby opisana wyżej systemowa reguła tworzenia przymiotników potencjalnych miała zastosowanie, w jego wypadku musiałby istnieć - akceptowany w terminologii specjalistów - leksem średniować, który byłby właściwa podstawa derywacyjną. W języku matematycznym takiego czasownika jednak nie ma, brak zatem wyrazu motywujaccego dla przymiotnika średniowalny. Dodajmy jeszcze, że gdyby leksem średniować istniał, to grupa średniowalna byłaby grupa, która można średniować, co dla matematyków nie znaczyłoby 'wyposażać w średnią, lecz 'uśredniać' - byłoby to więc określenie niespełniające kryterium precyzji znaczeniowej, nieodpowiednie jako komponent terminu specjalistycznego.

Jeśli chodzi o ocenę w zakresie kryteriów poprawności terminów, należy stwierdzić, że oba wskazane przymiotniki - średnialny oraz średniowalny - odpowiadają zasadzie ekonomiczności: są krótkie i wygodne w użyciu. To właśnie podporządkowanie się tendencji do ekonomizacji

12 Wykładnia znaczeń matematycznych w podanym zastosowaniu opiera się na interpretacji prof. A. Bobrowskiego; zob. przypis 1.

13 Zob. przypis 3. 
najprawdopodobniej sprowokowało matematyków do włączenia omawianego neologizmu do ich dyskursu bez poddania go weryfikacji normatywnej. ${ }^{14}$ Co więcej, neologizm ten szybko się zadomowił - jak pokazuje matematyczny uzus, formacja średniowalny spełnia także wymóg reproduktywności, co potwierdza pojawiajacy się w tekstach specjalistycznych rzeczownik średniowalność, por.:

(9) W trakcie referatu omówię grupy metryczne, tzn. grupy z niezmienniczymi metrykami oraz ultraprodukty takich grup. W dalszej części podam warunki prostotę i średniowalność ultraproduktów metrycznych grup oraz przykłady, np. pewne klasy grup liniowych nad nieskończonymi ciałami, grupy Higmana-Thompson oraz grupa IET. ${ }^{15}$

(10) Powyższa definicja nie jest historycznie pierwszą definicją średniowalności, a raczej geometryczną charakteryzacja. ${ }^{16}$

Niestety, brak poprawności systemowej nakazuje negatywnie ocenić ten przymiotnik i utworzony od niego rzeczownik. Przypomnijmy, że w przywołanej wcześniej dyskusji internetowej pojawiły się krytyczne głosy odnośnie do interesujacej nas formacji przymiotnikowej także ze względów brzmieniowych. Wydaje się, że oba przymiotniki: zarówno średnialny, jak i średniowalny, moga rodzić obiekcje ze względu na kryterium estetyczne. Dodajmy jednak, że wskazany jest tu pewien margines tolerancji, ponieważ po pierwsze, jest to kryterium subiektywne (bierze się w nim pod uwagę preferencje językowe użytkowników języka), a po drugie - mamy do czynienia $z$ terminologia specjalistyczna, w której wspomniane kryterium nie odgrywa najistotniejszej roli.

$\mathrm{W}$ poszukiwaniu polskiego odpowiednika ang. ameanable group, który spełniałby najistotniejsze dla terminów specjalistycznych kryteria poprawności, można by rozważyć frazę grupa średniowa, która dotychczas nie pojawiła się w żargonie matematyków, a której znaczenie da się eksplikować jako 'grupa zwiąana ze średnią'. Brzmienie tej nazwy może, co prawda, wzbudzać zastrzeżenia podobne jak w wypadku formacji średnialny czy średniowalny, poza tym przymiotnik średniowy może nasuwać skojarzenia ze średnia jakościa, czyli raczej słaba jakością. ${ }^{17}$ Formacja ta ma jednakże walory, którym na szali kryteriów oceny in-

14 Por. następujące stwierdzenie H. Jadackiej odnoszące się do zjawisk słowotwórstwa współczesnego: „W porównaniu ze stanem bezpośrednio powojennym uderza dążenie do rozwiązań najprostszych, bezrefleksyjnych, rutynowych, często także niedbałych, słowem - łatwych i wygodnych, może nawet tandetnych" [Jadacka 2001, 156].

15 https://math.uni.wroc.pl/seminar-item/2805 [dostęp: 17.10.2020].

16 http://pnowak.impan.pl/index/pub_files/piotr-nowak-uam.pdf [s. 9].

17 Jest to odniesienie do skojarzeń dla określenia średni utrwalonych w potocznej polszczyźnie, w której średni oznacza często 'niezbyt dobry, nieciekawy' [por. hasło średni w sjp. pwn, https://sjp.pwn.pl/szukaj/\%C5\%9Bredni.html] [dostęp: 17.10.2020]. 
nowacji terminologicznych należy przypisać znacząca wagę, jeśli chodzi o potencjał jej akceptowalności: 1) jest to innowacja utworzona zgodnie $z$ regułami systemu słowotwórczego, ${ }^{18}$ 2) nie wzbudza zastrzeżeń w zakresie kryterium ekonomiczności, 3) jest przejrzysta i precyzyjna znaczeniowo - znaczenie strukturalne jest komunikowane przez człony składowe derywatu, 4) wpisuje się w model słowotwórczy wykorzystywany $\mathrm{w}$ terminologii matematycznej, por. terminy takie jak przestrzeń ośrodkowa, funkcja liniowa, rozmaitość różniczkowa.

\section{PODSUMOWANIE}

Kwestia terminologicznego odpowiednika angielskiej nazwy amenable group $\mathrm{w}$ polskim dyskursie matematycznym jest zagadnieniem in statu nascendi. Zdaniem A. Witalisz „sztuczne tworzenie neologizmów rodzimych i unikanie zapożyczeń nie jest korzystnym rozwiazaniem w wypadku odmian zawodowych polszczyzny" [Witalisz 2019, 55]. Jednak sytuacja, która wywołała prezentowane tu rozważania, pokazuje, że matematycy wyraźnie sygnalizuja potrzebę polskojęzycznego odpowiednika omawianego zapożyczenia. Nie mając usankcjonowanego normatywnie i uzualnie polskiego odpowiednika, używaja - w zależności od zwyczaju wąskiego (uczelnianego) środowiska, $z$ którym sa związani - albo frazy grupa średniowalna, albo nazwy grupa dopuszczajaca średnia niezmiennicza bądź jej wariantów. Widoczny jest także różny stosunek specjalistów do istniejących propozycji nazewniczych.

Konkludując przedstawione w powyższej interpretacji argumenty, kontrowersje wokół dyskutowanego terminu i jego lingwistyczna ocenę należy podsumować następująco. Aby systemowa reguła tworzenia przymiotników $z$ sufiksem -alny miała poprawne zastosowanie w odniesieniu do wyrazu średniowalny, powinien być spełniony następujacy warunek formalny: istnieje - akceptowany w terminologii specjalistów - czasownik średniować, który byłby formalna podstawa czasownikową. Tak utworzony przymiotnik wykazuje znaczenie 'taki, który można średniować'. Nie istnieje jednak w żargonie matematycznym czasownik średniować, nie ma więc podstawy systemowej przymiotnika średniowalny. $Z$ kolei opcja utworzenia przymiotnika od bazy rzeczownikowej, gdzie podstawa jest wyraz średnia, skutkuje powstaniem formacji średnialny o znaczeniu 'związany ze średnia, dotyczacy średniej'. Tę formację odrzucaja jednak użytkownicy dyskursu, wskazując na brak przejrzystości znaczeniowej tego leksemu w kontekście specjalistycznym, w którym miałby być stosowany.

18 Jak podaje H. Jadacka, sufiks -owy to bardzo produktywny w polszczyźnie po 1989 r. przyrostek, który tworzy przymiotniki od baz rzeczownikowych, por. np. akcyzowy, biznesowy, laserowy, modowy [Jadacka 2001, 101]. 
Wobec braku akceptacji normatywnej dla wyżej wymienionych neologizmów jako alternatywa dla zwolenników polskojęzycznego odpowiednika angielskiej frazy amenable group został zaproponowany termin grupa średniowa. Argumenty uzasadniające jego funkcjonalność znajduja oparcie w kryteriach uznawanych za najważniejsze dla oceny poprawności polskiej terminologii specjalistycznej, wydaje się więc, że powinny pozytywnie wpłynąć na ewentualna akceptację tej nazwy w profesjolekcie matematyków - o tym jednak przesądza już oni sami.

\section{Bibliografia}

B. Dunaj, M. Mycawka, 2017, O potrzebnych i niepotrzebnych zapożyczeniach $z$ języka angielskiego, „Annales Universitatis Paedagogicae Cracoviensis. Studia Linguistica" 12.1, s. 67-80.

R. Grzegorczykowa, 1984, Zarys słowotwórstwa polskiego, Warszawa.

H. Jadacka, 2001, System słowotwórczy polszczyzny (1945-2000), Warszawa.

H. Jadacka, 2007, Kultura języka polskiego. Fleksja, słowotwórstwo, składnia, Warszawa.

I. Kolasa, 2014, Anglicyzmy $w$ korpusie mówionym rozmów między pracownikami korporacji [w:] M. Łukasik, B. Mikołajewska (red.), Języki specjalistyczne wczoraj, dziś i jutro, Warszawa, s. 159-175.

H. Kurkowska, 1953, Budowa stowotwórcza przymiotników polskich, Warszawa.

A. Markowski, 2012, Wielki słownik poprawnej polszczyzny PWN, Warszawa.

A. Nagórko, 1987, Zagadnienia derywacji przymiotników, Warszawa.

A. Nagórko, 2007, Zarys gramatyki polskiej, Warszawa.

A. Naruszewicz-Duchlińska, 2016, W naszym teamie - kilka uwag o socjolekcie korporacyjnym, „LingVaria” 22, s. 97-106.

L. Ptak, 2009, Przymiotniki o znaczeniu potencjalnym $w$ językach czeskim, słowackim i polskim, Wrocław.

A. Witalisz, 2019, Kryteria oceny poprawności anglicyzmów $w$ profesjolektach, „Poradnik Językowy” z. 8, s. 46-57.

P. Żmigrodzki (red.), Wielki słownik języka polskiego PAN (online); http://www. wsjp.pl 
DOI: 10.33896/PorJ.2021.4.7

PRZEMYSŁAW E. GEBBAL, WŁADYSŁAW T. MIODUNKA, DYDAKTYKA I METODYKA NAUCZANIA JEZYKA POLSKIEGO JAKO OBCEGO, Wydawnictwo Naukowe PWN, Warszawa 2020, ss. 454

Publikacja z zakresu glottodydaktyki polonistycznej jest podręcznikiem przeznaczonym - jak piszą we Wstępie autorzy - głównie dla osób przygotowujących się do pracy w zawodzie lektora języka polskiego jako obcego i drugiego lub nauczyciela polonisty we współczesnej szkole, w której przybywa uczniów $z$ doświadczeniem migracyjnym. Jest to trzecia pozycja w najnowszej serii Wydawnictwa Naukowego PWN poświęconej glottodydaktyce, po Metodyce nauczania języka niemieckiego Zofii Chłopek [2018] i Dydaktyce języków obcych. Wprowadzenie P.E. Gębala [2019].

Podręcznik składa się $z$ dwóch odmiennych, równych objętościowo, części: I. Dydaktyka języka polskiego w świecie - jej tradycje, dotychczasowy rozwój $i$ perspektywy oraz II. Metodyka nauczania i uczenia sie języka polskiego jako obcego $i$ drugiego. Jest opatrzony wstępem, bibliografia, streszczeniami w językach angielskim, ukraińskim i rosyjskim, zawiera także obszerne aneksy z materiałami dodatkowymi, omawianymi w tekście głównym.

Prezentowany jest w nim dorobek glottodydaktyki polonistycznej jako dziedziny akademickiej. Zgodnie z poczatkowymi rozważaniami definicyjnymi do glottodydaktyki polonistycznej należą dydaktyka języka polskiego jako obcego i drugiego oraz metodyka nauczania języka polskiego jako obcego i drugiego. Do zakresu dydaktyki autorzy zaliczaja badania uwarunkowań społecznych procesu nauczania polszczyzny (kim są uczący się, jakie są ich motywacje, jaki jest kontekst edukacyjny, kim sa nauczyciele) oraz opracowywanie propozycji programowych (cele, treści kształcenia, ich wybór i progresja) [s. 26-27].

Część I, poświęcona dydaktyce, składa się $z$ siedmiu rozdziałów. W pierwszym zawarto rozważania dotyczące definicji i przedmiotu glottodydaktyki polonistycznej, dydaktyki oraz metodyki języka polskiego jako obcego i drugiego. Rozdział drugi zbiera informacje o rozmówkach, słownikach (od Lexiconu J. Mączyńskiego) i gramatykach (od P. Statoriusa-Stojeńskiego), tworzonych od XVI w. do 1939 r. jako pomoce w nauczaniu języka polskiego jako obcego. Przegląd podręczników i opracowań teoretycznych jest kontynuowany w następnym rozdziale, poznajemy w ten sposób zmiany podejść metodycznych przyswajanych przez glottodydaktykę polska (od metody bezpośredniej i audiolingwalnej do podejścia komunikacyjnego). Kolejnym zagadnieniem $z$ zakresu dydaktyki jest charakterystyka uczących się języka polskiego za granicą i ich motywacji, typów 
szkół (poziom podstawowy, średni, wyższy), w których moga uczyć się polszczyzny, nauczycieli i lektorów języka polskiego w różnych krajach świata oraz ich kształcenia [rozdz. 4]. Następnie W.T. Miodunka zajął się kwestia polskiej polityki językowej, której częścia jest promocja polszczyzny w świecie i rozpoczęcie certyfikacji znajomości języka polskiego, podnoszącej prestiż naszego języka [rozdz. 5]. Przedstawił tu wiele prac $z$ tego zakresu, m.in. W. Lubasia, R. Szula, J. Mazura, A. Pawłowskiego, a także dane dotyczące liczby przystępujących do egzaminów i ośrodków prowadzących certyfikację. W rozdziale szóstym P. Gębal zawarł wiadomości dotyczące nauczania języka polskiego jako drugiego i jako języka edukacji szkolnej, jego organizacji, programów i koncepcji dydaktycznych. Przegląd tematów należących do dydaktyki języka polskiego jako obcego i drugiego zamykają krótkie opisy teorii wpływających na nauczanie języków: kognitywizmu, konstruktywizmu, teorii poznania i uczenia się, pragmatyzmu pedagogicznego, wielokulturowości, wielojęzyczności, neuroedukacji [rozdz. 7].

Drugi dział glottodydaktyki polonistycznej - metodyka nauczania języka polskiego jako obcego i drugiego - według podanej przez autorów definicji „uszczegóławia koncepcje dydaktyczne, przystosowując je do konkretnej praktyki edukacyjnej i odpowiadajac na pytania, jak nauczać i jak efektywnie się uczyć". Jej celem ,jest opracowywanie konkretnych metod i technik nauczania” [s. 27]. W części II publikacji znajdziemy sześć rozdziałów prezentujących dorobek glottodydaktyki polonistycznej w tym zakresie. Zebrano w niej wiadomości na temat rozwijania kompetencji językowych (fonologicznej, ortograficznej, gramatycznej, leksykalnej i semantycznej); rozwijania rozumienia ze słuchu i rozumienia tekstu pisanego, produkcji i interakcji ustnej i pisemnej oraz działań mediacyjnych; nauczania kultury polskiej; technologii informacyjno-komunikacyjnych; organizacji i planowania kursów i zajęć, a także metod testowania znajomości polszczyzny jako języka obcego.

Charakter podręcznika ujawnia spojrzenie na treści zawarte w wybranych podrozdziałach. Rozdział ósmy, którego przedmiotem jest rozwijanie kompetencji lingwistycznych, odnosi się do Programów nauczania języka polskiego jako obcego. Poziomy A1-C2 [Janowska 2016], opartych na podejściu komunikacyjnym. Fragment poświęcony rozwijaniu kompetencji fonologicznej W.T. Miodunka rozpoczął od przedstawienia systemu zasobu samogłosek i spółgłosek języka polskiego, ${ }^{1}$ podkreślił konieczność skupienia się na nauczaniu spółgłosek, począwszy od ich percepcji, a także przydatność podejścia kontrastywnego, zwrócił uwagę na opracowania zajmujące się najtrudniejszymi aspektami polskiej wymowy, a nasteppnie wymienił hasłowo techniki nauczania wymowy (za Programami) i niektóre pomoce dydaktyczne (bez kilku nowszych).

W rozdziale dziewiątym P. Gębal omówił kolejne podejście do nauczania języka polskiego jako obcego i drugiego, mianowicie podejście działaniowe, które podejściu komunikacyjnemu przeciwstawił. Na wstępie autor wyjaśnił, że w tym podejściu uczący się jest postrzegany jako autonomiczny użytkownik języka,

${ }^{1}$ Można zauważyć tu kilka usterek, np. zaliczenie samogłoski $y$ do średnich, a $e$ i o do niskich; pominięcie spółgłoski $x \mathrm{w}$ bezdźwięcznych; zaliczenie spółgłoski $n$ do spółgłosek wargowych (dwuwargowych) i pominięcie tu $b$ i $p$. 
który wykonuje określone zadania społeczne za pomoca komunikowania się i scharakteryzował je następująco:

W przeciwieństwie do dydaktyki komunikacyjnej, traktującej rozwijanie poszczególnych sprawności językowych (rozumienia ze słuchu, rozumienia tekstu pisanego, mówienia i pisania) jako zasadniczy cel dydaktyczny, dydaktyka działaniowa ukierunkowana jest na podejmowanie działań językowych. To właśnie dzięki nim dochodzi do rozwijania kompetencji językowej, osadzonej w szerokim kontekście społecznym, na który dydaktyka komunikacyjna nie zwracała aż takiej uwagi, gdyż oczekiwała punktowego rozwijania poszczególnych sprawności językowych [s. 26-265].

Podział działań językowych odnosi się do czterech kontekstów realizacji komunikacji: rozumienia tekstów, tworzenia tekstów, wymiany informacji, przetwarzania istniejących tekstów (...). Wszystkie wymienione działania mogą być realizowane w formie ustnej i pisemnej [s. 265].

Przykładem rozdziału dotyczącego rozwijania działań językowych może być ten dotyczacy produkcji i interakcji ustnej. P. Gębal zamieścił w nim uwagi na temat procesów mentalnych zachodzacych podczas mówienia oraz czynników psychologicznych i kulturowych wpływających na mówienie, przywołał wskazówki metodyczne: zasady rozwijania tej umiejętności (przygotowanie, powtarzanie, odtwarzanie, tworzenie), reguły tworzenia zajęć i postępowania na nich oraz techniki ćwiczeniowe (za Programami).

Autorzy Dydaktyki i metodyki nauczania języka polskiego jako obcego chcieli przedstawić czytelnikom jak najszerszy kontekst historyczny i teoretyczny dotyczący rozwoju glottodydaktyki polonistycznej dziedziny akademickiej, co sprawiło, że publikacja ta różni się od innych metodyk nauczania języków obcych i języka polskiego jako obcego. Podręcznik A. Seretny i E. Lipińskiej pt. ABC metodyki nauczania języka polskiego [2005], który autorzy przywołują we Wstepie, przede wszystkim przybliża techniki nauczania poszczególnych podsystemów polszczyzny i sprawności językowych (rozumienia ze słuchu, rozumienia tekstów pisanych, mówienia i pisania) oraz kontroli wyników nauczania wraz z przykładami zadań ilustrujacymi wszystkie techniki. Daje on czytelnikom - przyszłym i początkujacym lektorom języka polskiego jako obcego - praktyczną wiedzę o opracowywaniu ćwiczeń i prowadzeniu lekcji języka polskiego jako obcego. Metodyka nauczania języków obcych H. Komorowskiej [2001; 2005], będaca modelem dla autorek $A B C$ metodyki, również

ma charakter praktycznego poradnika, $z$ którego nauczyciel może się dowiedzieć, jak zaplanować kurs językowy, jak przygotować program nauczania, jak opracować konspekt lekcji, jak przeprowadzić na jego podstawie zajęcia, jak wybrać właściwą metodę nauczania i odpowiednie materiały [Komorowska 2005, 9],

a także poznać techniki nauczania języka i sprawności językowych oraz sprawdzania wyników nauczania, które zostały przez autorkę objaśnione i w części opatrzone przykładami. Również Metodyka nauczania języka niemieckiego. Podręcznik dla studentów germanistyki i poczatkujacych nauczycieli $Z$. Chłopek [2018], wydany w tej samej serii, co omawiana tu publikacja, przynosi podstawowe i praktyczne informacje o procesie uczenia się i nauczania języka obcego, 
nauczaniu elementów języka i sprawności językowych oraz sposobach kontroli osiagnięć uczniów. Prezentowane są w niej liczne przykłady zadań lekcyjnych i zadań dla studentów korzystających $z$ podręcznika wraz z ich omówieniami na końcu każdego rozdziału.

Z tego krótkiego przeglądu wynika, że publikacje metodyczne mają charakter praktyczny, zawieraja opisy technik stosowanych w nauczaniu języków obcych i przykłady konkretnych zadań. Dydaktyka i metodyka nauczania języka polskiego jako obcego natomiast jest poświęcona prezentacji dorobku badaczy tworzacych w obszarze glottodydaktyki polonistycznej i zapoznaniu przyszłych lektorów języka polskiego jako obcego $z$ refleksją teoretyczną kształtujaca współczesne nauczanie języka polskiego jako obcego i drugiego. Jest to publikacja, która nie ma odpowiedników w dotychczasowej literaturze przedmiotu.

\section{Bibliografia}

Z. Chłopek, 2018, Metodyka nauczania języka niemieckiego. Podręcznik dla studentów germanistyki i początkujacych nauczycieli, Warszawa.

I. Janowska i in., 2016, Programy nauczania języka polskiego jako obcego. Poziomy A1-C2, Kraków.

H. Komorowska, 2005, Metodyka nauczania języków obcych, Warszawa.

A. Seretny, E. Lipińska, 2005, ABC metodyki nauczania języka polskiego jako obcego, Kraków.

Marta Piasecka

(Uniwersytet Warszawski, e-mail: marta.piasecka@uw.edu.pl)

ORCID: 0000-0001-6444-5867 


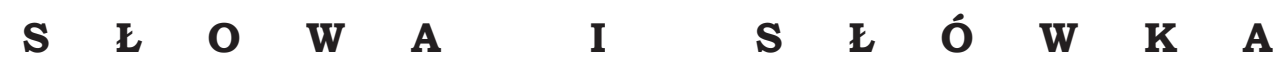

DOI: $10.33896 /$ PorJ.2021.4.8

\section{SPOEEM, SPOEECZNOŚĆ, SPOEECZEŃSTWO}

W XVI-wiecznym słowniku łacińsko-polskim Jana Mączyńskiego z 1564 r. (Lexicon latino-polonicum...) interesująca nas rodzina wyrazów jest reprezentowana przez następujące leksemy: spolnie, spolność, spolny, wszospolność, wszospolny, po społu, społecznie, społeczny, społek, społem, wespołek [zob. Kuraszkiewicz 1963]. Jest to więc słownictwo dawne, dobrze zadomowione w polszczyźnie. Różna jest jednak jego geneza. Aleksander Brückner cała tę rodzinę wyrazów wywodzi od podstawy pół < psł. * polø [BSEJP], podobnie Wiesław Boryś, który ponadto podaje etymologie niektórych wyrazów lub wyrażeń - por. społem < psł. * sı polъmъ 'z połowa; razem'; pospołu < stpol. po społu < stpol. społu 'razem z innymi; wspólnie' [BorSEJP]. Podobna genezę należy przypisać formom spolnie, spolność, spolny (por. współczesne wspólnie, wspólność, wspólny). Sa to zatem formy rodzime o genezie prasłowiańskiej, istotny jest tu jednak także wpływ języka czeskiego, który upowszechnił w polszczyźnie niektóre formy, poczynając od XVI w. - por. pol. społek 'towarzystwo, spółka' < czes. spolek 'spółka, wspólnota', pol. społeczny < czes. společny 'wspólny', pol. społeczność < czes. společnost 'wspólnota, spółka; społeczeństwo', pol. społecznie < czes. společně 'wspólnie, razem' [zob. BSB]. O infiltracji języka czeskiego w wypadku tych wyrazów świadczy to, że formy czeskie sa powszechnie notowane już w średniowieczu, podczas gdy formy polskie upowszechniają się dopiero w okresie średniopolskim (XVI-XVIII w.), a pamiętać należy, że w XV i XVI w. język czeski był uznawany za wzorcowy w porównaniu $z$ polszczyzną. Poświadczenie tych procesów znajdujemy m.in. w inwokacji do Kazania wtórego [o] miłości ku ojczyźnie z Kazań sejmowych Piotra Skargi:

To wam rozkazuję - mówi Pan Jezus - abyście się społecznie miłowali. Pokój mój daję wam, pokój mój zostawuję wam [Skarga 30].

Brak jednak wśród tych wyrazów formy społeczeństwo, która w dzisiejszej polszczyźnie ma chyba największą frekwencję. Nie występuje ona w tekstach ani z XVI, ani z XVII w., a w wieku XVIII pojawia się dopiero w jego drugiej połowie, pierwotnie jako rzadziej występujacy synonim rzeczownika społeczność.

Liberiusz papież społeczność brał $z$ heretykami. 
Ludzie $z$ sobą łączący się, żeby podług pewnych przepisów do społecznego kresu doszli, zowią się spoleczeństwem.

Społeczność jest jedną moralną istnością, której członkami są obywatele.

Słowność w interesach, ludzkość w obcowaniu, są to ogniwa, z których się składa łańcuch porządnego wspołeczeństwa między ludźmi [SL].

Łatwo zauważyć, że w powyższych cytatach rzeczownik społeczeństwo ma dwa znaczenia: 'zbiór osób kierujących się wspólnymi zasadami / przepisami ładu społecznego; wspólnota', 'obcowanie ludzi, utrzymywanie kontaktów międzyludzkich'. Oba te znaczenia w większym zakresie sa rejestrowane w tekstach średniopolskich w odniesieniu do wyrazu społeczność, jak wiemy o genezie XVI-wiecznej, możemy zatem przyjąć, że druga połowa XVIII w. to okres, w którym forma starsza (społeczność) zaczyna powoli ograniczać zakres swego występowania, a forma nowsza (społeczeństwo) ten zakres zwiększa, ale nie uzyskuje jeszcze prymatu. Jest to faza, w której zaczyna się zaznaczać nowe szerokie znaczenie rzeczownika społeczeństwo ('ogół ludzi pozostających we wzajemnych relacjach - duża wspólnota'), a zarazem zaczyna się utrwalać jako główne węższe znaczenie rzeczownika społeczność ('ludzie należący do poszczególnych środowisk - mniejsza wspólnota').

Procesy kształtowania się dominant znaczeniowych obu wyrazów trwały bez mała dwieście lat. Witold Doroszewski w Słowniku języka polskiego z połowy XX w. podaje trzy znaczenia hasła społeczeństwo: 1. 'ogół ludzi pozostajacych we wzajemnych stosunkach wynikajacych $z$ ich udziału w procesach produkcyjnych i w życiu kulturalnym; ogół obywateli danego kraju, okręgu, miasta itp.', 2. 'ludzie poszczególnych środowisk zawodowych, społecznych', 3. daw. a) 'towarzystwo, obcowanie $z$ kimś', b) 'wspólność, wspólnota', a odpowiednie znaczenia hasła społeczność odsyła do nich, nie ma więc watpliwości, że to społeczeństwo jest hasłem prymarnym, nadrzęnym [SJPDor, VIII]. Z kolei w słownikach pod redakcją Stanisława Dubisza [USJP 2003; WSJP PWN 2018] oba te hasła maja już rozdzielne pojedyncze znaczenia, przy czym w haśle społeczeństwo parafraza znaczeniowa dotyczy ogółu ludzi (dużej wspólnoty), a w haśle społeczność - z kwalifikatorem książk. ludzi poszczególnych środowisk (mniejszej wspólnoty). Na podstawie tych notacji można przyjąć, że proces krystalizacji dominant znaczeniowych obu tych rzeczowników został zakończony na przełomie XX i XXI w.

We współczesnej polszczyźnie właśnie rzeczownik społeczeństwo stanowi centrum leksykalne tej rodziny wyrazów, należy także do słownictwa podstawowego (wspólnego różnym odmianom języka ogólnopolskiego), co znajduje wyraz w licznych połaczeniach wyrazowych (np. społeczeństwo cywilizowane, demokratyczne, obywatelskie, konsolidacja społeczeństwa), związkach frazeologicznych (np. wyrzutek społeczeństwa / społeczny, być, zostać, znaleźć się poza nawiasem społeczeństwa) i zestawieniach terminologicznych (np. społeczeństwo owadów), w których występuje. Odsyłajacc do ich odpowiednich notacji słownikowych, warto przytoczyć na zakończenie tego szkicu jedno z tzw. skrzydlatych słów, zawierające konstatację dotyczaca „wspólnotowości” (wszak istota społeczeństwa na niej się zasadza) polskiego społeczeństwa, która możemy odnieść zarówno do naszej historii, jak i do współczesności: 
Jesteśmy żadnym społeczeństwem. Jesteśmy wielkim sztandarem narodowym [Cyprian Kamil Norwid].

S.D.

\section{Bibliografia}

BorSEJP - W. Boryś, Słownik etymologiczny języka polskiego, Kraków 2005.

A. Brückner, Słownik etymologiczny języka polskiego, Warszawa 1970.

BSB - M. Basaj, J. Siatkowski, Bohemizmy w języku polskim. Słownik, Warszawa 2006.

W. Kuraszkiewicz (oprac.), Wyrazy polskie w słowniku łacińsko-polskim Jana Maczyńskiego, Wrocław 1963.

H. Markiewicz, A. Romanowski, Skrzydlate słowa, Warszawa 1990.

P. Skarga, Kazania sejmowe, oprac. J. Tazbir, M. Korolko, Warszawa 2003.

SJPDor. - W. Doroszewski (red.), Słownik języka polskiego, t. VIII, Warszawa 1966.

SL - S.B. Linde, Słownik języka polskiego, t. V, Lwów 1859, wyd. Warszawa 1995.

USJP - S. Dubisz (red. nauk.), Uniwersalny słownik języka polskiego, t. IV, Warszawa 2003.

B. Vydra, Słownik polsko-czeski, Praga 1951.

WSJP PWN - S. Dubisz (red. nauk.), Wielki słownik języka polskiego PWN, t. IV, Warszawa 2018. 


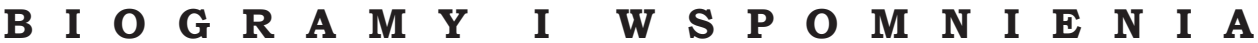

DOI: $10.33896 /$ PorJ.2021.4.9

\section{TERESA IGLIKOWSKA (1926-2021)}

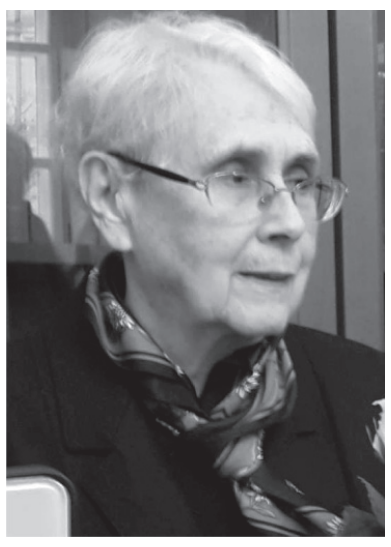

19 stycznia 2021 roku odeszła od nas Pani Teresa Iglikowska, która tworzyła podwaliny rodzacej się w połowie XX wieku warszawskiej glottodydaktyki polonistycznej, autorka cennych prac z tej dziedziny, zbiorów ćwiczeń, a także współautorka pierwszego podręcznika języka polskiego dla cudzoziemców opracowanego metodycznie $z$ myślą o niezaawansowanych, czyli używając dzisiejszej terminologii - przeznaczonego dla poziomu A1. Była mistrzem akademickiej dydaktyki, nauczycielem wielu pokoleń polonistów zagranicznych, którzy dziś sa pracownikami naukowymi wydziałów slawistycznych na uniwersytetach europejskich, amerykańskich i azjatyckich, tłumaczami polskiej literatury, autorami monografii poświęconych polskiej kulturze i historii.

Studia polonistyczne na Uniwersytecie Warszawskim rozpoczęła w $1948 \mathrm{r}$. Pracę magisterska pt. $Z$ historii funkcji przyimka na $w$ języku polskim, napisana pod kierunkiem Witolda Doroszewskiego, obroniła w 1952 r., a rozprawę doktorska pt. „Viertzig Dialogi” Mikołaja Volckmara-jako podstawa badania języka polskiego $w$ XVII $w$. zaczęła przygotowywać na początku lat 60 . XX w. ${ }^{1}$

Swoje zainteresowania językoznawcze ujawniła już na II roku studiów, po którym odbył się pierwszy letni obóz dialektologiczny na Warmii i Mazurach. Wzięła w nim udział razem $z$ innymi studentami i pracownikami Zakładu Języka Polskiego, stanowiącego wówczas część Wydziału Humanistycznego, a później Wydziału Filologicznego UW.

W grudniu 1950 r. została zastępca asystenta. Funkcję tę pełnili najzdolniejsi studenci, którzy nie prowadzili zajęć, ale zajmowali się sprawami administracyjnymi Zakładu, pomagali w pracach zakładowej biblioteki i byli opiekunami poszczególnych grup studenckich. Bezpośrednio po studiach rozpoczęła okres

${ }^{1} \mathrm{Z}$ badań archiwalnych przeprowadzonych przez P. Kajaka, przygotowujacego opracowanie na temat historii „Polonicum” oraz dokonań warszawskiej szkoły glottodydaktyki polonistycznej, wynika, że przewód doktorski miała Teresa Iglikowska otwarty 25 VI 1963 r., a promotorem jej pracy miał być prof. W. Doroszewski. 
tzw. aspirantury, w czasie której prowadziła zajęcia dydaktyczne $z$ gramatyki języka polskiego, ze stylistyki i kultury języka. Współpracowała także $z$ Pracownia Historii Języka, w której pod kierunkiem prof. Haliny Konecznej przygotowywała hasła do tworzonego w tym czasie Słownika Jana Chryzostoma Paska.

W roku akademickim 1956/57 wyjechała jako wykładowca do Chin, gdzie w pekińskim Instytucie Języków Słowiańskich prowadziła zajęcia $z$ gramatyki języka polskiego, do dziś ciepło wspominane przez jej dawnych słuchaczy. Był wśród nich prof. Yang Deyou, wybitny chiński polonista i anglista, który wspomina w jednym ze swoich listów, że zaczął studiowanie języka polskiego w 1956 r. i stał się wówczas miłośnikiem kultury polskiej. ${ }^{2}$ Po powrocie z Chin Teresa Iglikowska była na krótko zatrudniona w Zakładzie Metodyki Nauczania Języka Polskiego, którym kierował w tym czasie prof. Bronisław Wieczorkiewicz, a później przeszła do Zakładu Stylistyki i Kultury Języka, który w końcu lat 50. został przeniesiony z Wydziału Dziennikarstwa na Wydział Filologiczny, a kierowała nim wówczas prof. Halina Kurkowska.

Oprócz odbywania kursowych zajęć dla studentów filologii polskiej Teresa Iglikowska wykładała w tym czasie także na kursach języka polskiego jako obcego, bo nauczanie obcokrajowców - jak wielokrotnie podkreślała - dawało jej najwięcej satysfakcji. Jak wspominała, w ramach pensum prowadziła całoroczne lektoraty języka polskiego dla cudzoziemców, organizowane przez Biuro Międzynarodowych Kursów dla Slawistów, przekształcone później w Studium, następnie w Instytut, a w końcu w Centrum Języka Polskiego i Kultury Polskiej dla Cudzoziemców. ${ }^{3}$ Ze wszystkimi tymi instytucjami współpracowała przez cały czas bardzo aktywnie, układając programy studiów, opracowując materiały dydaktyczne dla słuchaczy i uczac języka polskiego na kolejnych lektoratach nie tylko w ciagu roku akademickiego, ale także na kursach wakacyjnych dla slawistów. Po pierwszym takim kursie w 1958 roku wspólnie z Haliną Kurkowską, Mieczysławem Szymczakiem i Eugenią Sowińska opracowała pierwsze opublikowane drukiem Materiały do lektoratu języka polskiego. ${ }^{4}$ Jej autorstwa była wydana jako osobna książka część II tych materiałów, przeznaczona do nauczania grup średnio zaawansowanych.

Jednocześnie $z$ opracowywaniem skryptów do nauczania cudzoziemców zbierała Teresa Iglikowska materiały do przygotowywanego wspólnie $z$ Halina Kurkowską Słownika frazeologicznego języka polskiego, którego Zeszyt próbny

2 Jego słowa przytacza Beata Polanowska-Sygulska z Uniwersytetu Jagiellońskiego $\mathrm{w}$ artykule pt. Historia pewnej przedmowy. Na marginesie chińskiego tłumaczenia „Unfinished Dialogue” [2015, 21]. Podobna wypowiedź profesora Yang Deyou przekazał jego syn, który w 2014 r. odbierał w jego imieniu nagrodę „Polonicum”, por. A. Mazurkiewicz 2014 , s. 42.

${ }^{3}$ W 2006 roku Centrum Języka Polskiego i Kultury Polskiej dla Cudzoziemców obchodziło 50-lecie swojego istnienia. Jego historie przedstawił w tomie jubileuszowym S. Dubisz w szkicu pt. Do czego glottodydaktyka jest potrzebna? Tytutem wprowadzenia - na 50-lecie „Polonicum” [2006].

${ }^{4}$ Materiały te [Iglikowska 1958; Kurkowska, Sowińska 1958; Szymczak 1958] sa wspominane $\mathrm{m}$.in. przez W. Jekiela jako opracowywane w wyniku doraźnych potrzeb zwiazanych $z$ kursami, powielane na powielaczu w niewielkiej liczbie egzemplarzy, nieustannie wznawiane i nieustannie poprawiane, ale mimo to rozchwytywane i w kraju, i za granica [por. Jekiel 2006, 46]. 
ukazał się w 1963 r., a w 1966 r. Zeszyt pierwszy, grupujacy polskie frazeologizmy zwiąane tematycznie $z$ czasem, przestrzenia, ilością, liczba i stopniem [Iglikowska, Kurkowska 1966]. Słownik miał układ tematyczny, co znacznie ułatwiało korzystanie $z$ niego przy tworzeniu tekstu oraz podczas pracy nad przekładem. Nic dziwnego, że mimo wydania go jako publikacji o niskiej jakości pod względem technicznym i w niewielkim nakładzie, do dziś jest pozycją poszukiwana przez polonistów w Polsce i za granica. Nigdy nie zostały jednak opracowane kolejne zeszyty Słownika. Być może dlatego, że drogi autorek rozeszły się i każda zajęła się innymi ważnymi zadaniami. Halina Kurkowska razem z Danuta Buttler i Halina Satkiewicz rozpoczęły prace nad bardzo potrzebnym w dydaktyce polonistycznej podręcznikiem do kultury języka, a Teresa Iglikowska w 1964 roku przeniosła się z Zakładu Stylistyki i Kultury Języka do Instytutu Języka i Kultury Polskiej dla Cudzoziemców „Polonicum”, ${ }^{5}$ gdzie rozpoczęła razem $z$ Lidia Kacprzak pracę nad podręcznikiem do nauczania języka polskiego jako obcego dla grup niezaawansowanych. Część pierwsza podręcznika przeznaczona do pracy ze studentami, zawierajacca teksty, ćwiczenia oraz metodycznie zaprezentowany materiał gramatyczny, była gotowa już w 1968 r., a wkrótce potem ukazała się mniejsza objętościowo część druga z komentarzem gramatycznym, informacjami dotyczacymi wymowy polskiej oraz charakterystyki komunikacyjnej języka polskiego.

Podręcznik do dziś jest uważany za jeden z najlepszych pod względem metodycznym. ${ }^{6}$ Chociaż dialogi odnoszą się do realiów sprzed 50 lat, lektorzy często wykorzystuja go jeszcze teraz na swoich zajęciach ze względu na perfekcyjnie wprowadzane zagadnienia gramatyczne, doskonale dobrane ćwiczenia fonetyczne i partie utrwalajace poznany materiał językowy. Każda z 30 lekcji została przez autorki zaprojektowana jako spójna całość, w której nie ma zbędnych słów ani przypadkowych komentarzy. Cudzoziemiec uczący się polskiego jest prowadzony krok po kroku, opanowuje kolejne trudności gramatyczne i poznaje nowe słowa bez zbytniego wysiłku, nie oczekując nawet pomocy lektora. Część druga podręcznika zawierajaca komentarz gramatyczny jest już nieco trudniejsza, ale za to wszelkie wyjaśnienia sa w niej oparte na rzetelnej wiedzy językoznawczej, dotyczącej m.in. zróżnicowania polskich końcówek deklinacyjnych, oboczności występujących w odmianie rzeczowników i czasowników, funkcji spółgłosek historycznie miękkich oraz dyftongicznej wymowy samogłosek nosowych. Niewatpliwą wartościa tej części podręcznika jest prezentacja całościowa poszczególnych zagadnień gramatycznych, np. pokazanie wszystkich możliwych w polszczyźnie końcówek rzeczownika w mianowniku albo wszystkich alternacji tematycznych, a nie tylko wybranych, najbardziej przydatnych komunikacyjnie, jak to jest w większości podręczników wydawanych współcześnie. Takie podej-

${ }^{5}$ L. Kacprzak w opracowaniu pt. Polonicum Uniwersytetu Warszawskiego [2006, 24-25] wymienia kolejne etapy zatrudnienia Teresy Iglikowskiej w Instytucie „Polonicum”: 1964-1969 na stanowisku lektora, 1969-1978 na stanowisku wykładowcy, 1978-1983 na stanowisku starszego wykładowcy.

6 Opinię tę potwierdzaja liczni autorzy, m.in. W. Jekiel we wspomnieniach dotyczących początków „Polonicum” [por. Jekiel 2006, 46] oraz J. Porayski-Pomsta w rozdziale zawierającym charakterystykę podręczników opracowanych w „Polonicum” [por. PorayskiPomsta 2006, 220-222]. 
ście wynikało $z$ potrzeby przekazania uczacym się nie tylko umiejętności mówienia po polsku, ale także wiedzy o polszczyźnie, która zdaniem Teresy Iglikowskiej jest bardzo pomocna w poznawaniu języka obcego.

Równie cenna publikacją Teresy Iglikowskiej okazały się Ćwiczenia gramatyczno-leksykalne na lektoraty języka polskiego dla cudzoziemców. Wielokrotnie wznawiane, są niezastapiona pomocą dydaktyczną na każdym kursie języka polskiego jako obcego. Część pierwsza dotyczy różnych sposobów wyrażania w języku polskim subiektu, atrybutu, obiektu oraz nazywania samej czynności. W części drugiej autorka zebrała ćwiczenia dotyczące wyrażania miejsca, kierunku i czasu, łącznie $z$ określaniem pory dnia i godziny. Także w tym zbiorze czytelnik znajdzie wszystkie możliwe konstrukcje pełniące w tekście konkretne funkcje składniowe, bez pominięcia żadnej, nawet tej, która zalicza się do wyjątków.

Ze wszystkich tych publikacji korzystałam jako początkujący lektor języka polskiego, prowadząc zajęcia na wakacyjnych kursach dla cudzoziemców organizowanych przez „Polonicum”. Wtedy także poznałam osobiście Teresę Iglikowska - osobę skromna, nierzucająca się w oczy, ale ciesząca się prawdziwym autorytetem wśród słuchaczy. Były to jej ostatnie lata przed przejściem na emeryturę w 1983 roku, która jednak nie przerwała aktywności naukowej Teresy Iglikowskiej. Była obecna na wszystkich konferencjach naukowych organizowanych w Instytucie Języka Polskiego, uczestniczyła w pracach Oddziału Warszawskiego Towarzystwa Kultury Języka, pomagała od strony merytorycznej w tworzeniu programów kolejnych wakacyjnych kursów języka polskiego dla cudzoziemców, dopingowała młodych pracowników naukowych do zdobywania stopni naukowych, pomagała im zaplanować ciekawe metodycznie zajęcia. Szkoda tylko, że nie zebrała nigdy w postaci monografii swoich poglądów na metodykę nauczania języka polskiego jako obcego i nie dostosowała swoich podręczników oraz zbiorów ćwiczeń do nowych oczekiwań programowych, żeby mogły służyć kolejnym pokoleniom słuchaczy.

Przez całe życie na swój sposób pozostawała wierna sobie i swojej wiedzy językoznawczej, która potrafiła umiejętnie łączyć z potrzebami glottodydaktycznymi. Wychowała grono uczniów, mimo że nie miała tytułu profesora i nie prowadziła własnego seminarium. Byłam jednym $z$ nich, najpierw jako pracownik Instytutu Języka Polskiego odbywajacy zajęcia na wakacyjnych kursach języka i kultury polskiej dla cudzoziemców, później jako lektor na Uniwersytecie „La Sapienza” w Rzymie, wreszcie jako wykładowca na wrześniowych kursach dla tłumaczy i na studiach podyplomowych dla przyszłych lektorów. Wszędzie towarzyszyły mi prace Pani Teresy i jej idea, aby podstawa nabywania przez studentów umiejętności komunikacyjnych była zawsze wiedza naukowa. To było jej najważniejsze przesłanie.

W czasie jedynej krótkiej wizyty w domu Pani Teresy mogłam przekonać się, jak bogatą bibliotekę zgromadziła na niewielkiej powierzchni. Na półkach stały wszystkie tomy słowników S.B. Lindego i W. Doroszewskiego, prace językoznawcze polskie i zagraniczne wydawane w czasie ostatnich kilkudziesięciu lat. Interesowała się wszystkim, co mogło się przydać w pracy lektora. W czasie licznych spotkań oficjalnych i prywatnych rozmawiałyśmy nie tylko o najskuteczniejszych metodach nauczania cudzoziemców języka polskiego i o nowych tenden- 
cjach w glottodydaktyce, ale także o przeszłości Wydziału Polonistyki, z którym obie byłyśmy zwiazane zawodowo i naukowo.

Parę lat temu w czasie jednego $z$ takich spotkań Pani Teresa przekazała mi trzy strony wspomnień $z$ początkowego okresu swojego zatrudnienia na Uniwersytecie Warszawskim i zdjęcia z pierwszych obozów dialektologicznych, organizowanych przez prof. W. Doroszewskiego w latach 1950 i 1951. Prosiła, aby wykorzystać te materiały w pracy na temat dziejów językoznawstwa warszawskiego, przygotowywanej wówczas przez Towarzystwo Kultury Języka. W przekazanym tekście opisała swoje koleżanki i kolegów ze studiów - Barbarę Bartnicką, Irminę Judycka, Tadeusza Drewnowskiego, Hipolita Szkiłązia i Janusza Siatkowskiego oraz prowadzących zajęcia językoznawcze w czasie, kiedy studiowała, czyli Witolda Doroszewskiego, Halinę Kurkowską, Janinę Kraszewską i Wandę Pomianowską. Na jednym $z$ obozowych zdjęć, $z$ których dwa dołączam do tego wspomnienia, stoi w towarzystwie Jana Tokarskiego, na drugim obok Stanisława Skorupki. Jak wielokrotnie podkreślała, w czasie studiów dane jej było przebywać w towarzystwie najwybitniejszych polskich językoznawców.

Swój udział w życiu akademickim i wkład do glottodydaktyki warszawskiej skromnie bagatelizowała. Doceniali to jednak inni. W 2015 roku otrzymała tytuł honorowego członka Towarzystwa Kultury Języka, a w 2016 roku została odznaczona medalem 200-lecia Uniwersytetu Warszawskiego. Jak mówiła, odbierając te oficjalne wyróżnienia, dla niej najważniejszy był zawsze przyjazny stosunek własnego środowiska do tego, co robiła.

Chociaż świat jest tak urządzony, że każdy kiedyś musi odejść, wydawało się, że nie dotyczy to Pani Teresy Iglikowskiej. Do ostatnich dni była aktywna, interesowała się planami konferencyjnymi Wydziału, mimo panujacej pandemii utrzymywała kontakt telefoniczny z pracownikami „Polonicum” i z koleżankami z Towarzystwa Kultury Języka. Kiedy odeszła i nagle, niespodziewanie zabrakło Jej wśród nas, każdy rozumiał, że straciliśmy niezwykłego człowieka o rzadko dziś spotykanej osobowości. Pod tym, co napisali w nekrologu Jej współpracownicy z Centrum Języka Polskiego i Kultury Polskiej „Polonicum” chętnie podpisze się każdy, kto miał okazję spotkać Ja choć raz na swojej akademickiej drodze: „Żegnamy Mistrzynię, w której znajdowaliśmy wsparcie, dobroć i przyjaźń”.

Elżbieta Wierzbicka-Piotrowska (Uniwersytet Warszawski, e-mail: elzbieta.piotrowska@uw.edu.pl) ORCID: 0000-0002-2310-2814 

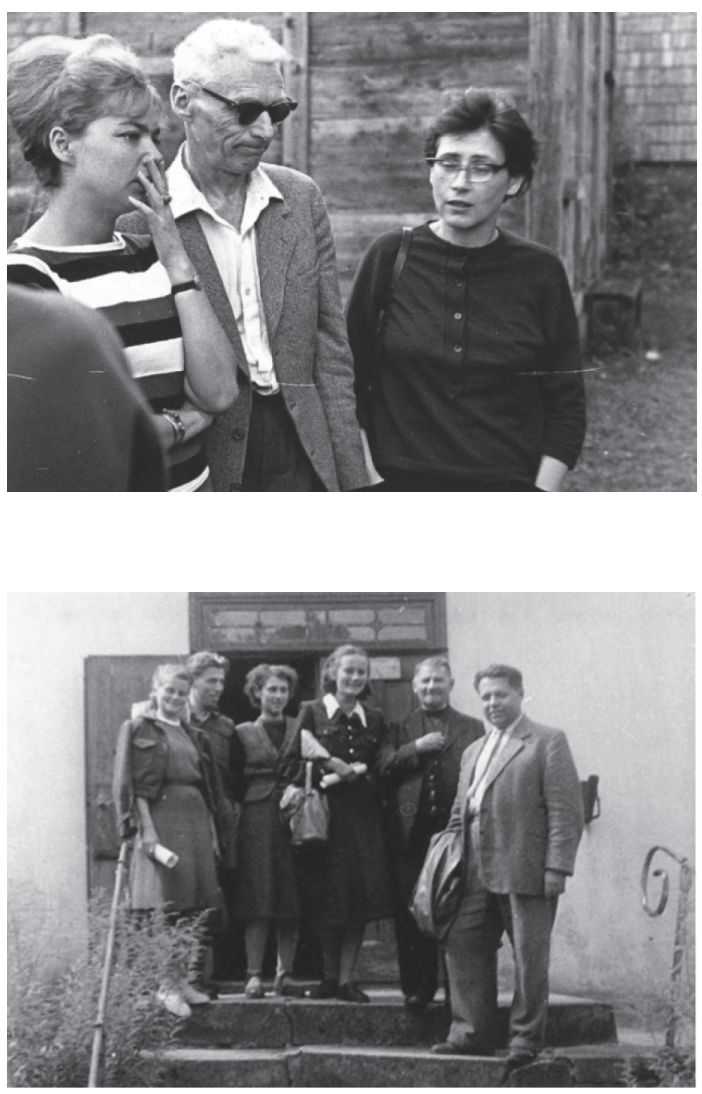

Teresa Iglikowska (pierwsza $z$ prawej) na obozie dialektologicznym na Warmii i Mazurach w 1950 r.
Teresa Iglikowska (czwarta z prawej) na obozie dialektologicznym na Warmii i Mazurach w 1951 r.

\section{Bibliografia}

S. Dubisz, Do czego glottodydaktyka jest potrzebna? Tytułem wprowadzenia - na 50-lecie „Polonicum” [w:] D. Knysz-Tomaszewska, J. Porayski-Pomsta, K. Wrocławski, Na chwałe i pożytek nasz wzajemny, Warszawa 2006, s. $15-18$.

T. Iglikowska, Materiały do lektoratu języka polskiego, z. II, Warszawa 1958.

T. Iglikowska, H. Kurkowska, Mały słownik frazeologiczny, z. 1: Czas, przestrzeń, ilość, liczba, stopień, Warszawa 1966.

T. Iglikowska, L. Kacprzak, Język polski dla cudzoziemców: podręcznik dla niezaawansowanych, cz. 1 i 2, Warszawa 1968 (kolejne wydania: 1974, 1978, 1988).

T. Iglikowska, Ćwiczenia gramatyczno-leksykalne na lektoraty języka polskiego dla cudzoziemców, cz. 1 i 2, Warszawa 1975 (kolejne wydania: 1979, 1990, 1995).

W. Jekiel, Pierwsze lata [w:] D. Knysz-Tomaszewska, J. Porayski-Pomsta, K. Wrocławski, Na chwałe i pożytek nasz wzajemny, Warszawa 2006, s. 43-52. 
H. Kurkowska, E. Sowińska, Materiały do lektoratu języka polskiego, cz. III, Warszawa 1958.

A. Mazurkiewicz, Nagroda POLONICUM 2014, „Kwartalnik Polonicum” nr 18/2015, s. 41-44.

B. Polanowska-Sygulska, Historia pewnej przedmowy. Na marginesie chinskiego tłumaczenia „Unfinished Dialogue” (2015), „Archiwum Filozofii Prawa i Filozofii Społecznej" nr 2/2015, s. 20-26.

J. Porayski-Pomsta, Podręczniki do nauki języka polskiego opracowane $w$ Polonicum. Próba oceny glottodydaktycznej [w:] D. Knysz-Tomaszewska, J. Porayski-Pomsta, K. Wrocławski, Na chwałe i pożytek nasz wzajemny, Warszawa 2006, s. 217-227.

M. Szymczak, Materiały do lektoratu języka polskiego, cz. I, Warszawa 1958 (kolejne wydania: 1961, 1965). 


\section{INFORMACJE DLA AUTORÓW „PORADNIKA JĘZYKOWEGO”}

Prosimy Autorów o nadsyłanie artykułów, rozpraw, recenzji publikacji językoznawczych oraz sprawozdań z konferencji, sympozjów i spotkań, ponieważ chcemy, aby „Poradnik Językowy” w szerokim zakresie informował o życiu naukowym w kraju i za granicą.

Uprzejmie prosimy Autorów o przestrzeganie następujących zasad redakcyjnych:

- Objętość artykułu nie powinna przekraczać 14 stron znormalizowanego maszynopisu (ok. 25000 znaków ze spacjami), objętość recenzji zaś - stron 7 (ok. 12000 znaków ze spacjami).

- Prosimy o dołączenie do tekstu artykułu krótkiego (10 wersów) streszczenia i słów kluczowych w języku polskim. Streszczenie powinno zawierać: 1) uzasadnienie podjętych badań; 2) prezentację uzyskanych wyników; 3) omówienie zastosowanej metody badawczej.

- W cudzysłowie podajemy tytuły czasopism oraz cytaty - jeżeli nie sa wyodrębnione w inny sposób (np. inną wielkością pisma).

- Kursywa wyodrębniamy wszystkie omawiane wyrazy, zwroty i zdania, ponadto tytuły książek i części prac, tzn. rozdziałów i artykułów, oraz zwroty obcojęzyczne wplecione w tekst polski.

- Podkreślenia tekstowe oznaczamy spacja (druk rozstrzelony).

- Znaczenie wyrazów podajemy w łapkach ".

- Prace należy dostarczać w formie papierowej oraz wersji elektronicznej na konto: poradnikjezykowy@uw.edu.pl

- Autorów przysyłajacych swoje prace po raz pierwszy prosimy o czytelne podanie imienia, nazwiska, tytułu naukowego lub zawodowego, numeru ORCID, nazwy ośrodka naukowego (przy którym chca afiliować tekst artykułu), adresu prywatnego, adresu e-mail i numeru telefonu. Pliki prosimy przysyłać w formacie edytora MS Word (*doc, *.rtf).

- Autorzy sa zobowiazani do złożenia oświadczenia o oryginalności autorskiej tekstów.

Redakcja nie zwraca tekstów niezamawianych. 


\section{N F O R M A C J A O P R E N U M E R A C I E}

\section{„PORADNIKA JĘZYKOWEGO”}

Ceny „Poradnika Językowego” w roku 2021:

prenumerata roczna (10 numerów) - 170,00 zł, opłata za pojedynczy numer - 17,00 zł.

Zamówienia na pojedyncze egzemplarze pisma można składać bezpośrednio na stronie wydawnictwa: www.elipsa.pl lub kierować na adres e-mail: sklep@elipsa.pl

\section{Prenumerata krajowa i zagraniczna}

Zamówienia na prenumeratę $\mathrm{w}$ wersji papierowej można składać bezpośrednio na stronie

RUCH SA, www.prenumerata.ruch.com.pl

Ewentualne pytania prosimy kierować na adres e-mail: prenumerata@ruch.com.pl lub kontaktując się z Centrum Obsługi Klienta „RUCH” pod numerami: 226937000 lub 801800803 - czynne w dni robocze w godzinach $7^{00}-17^{00}$. Koszt połaczenia wg taryfy operatora.

Zamówienia na prenumeratę przyjmują również:

KOLPORTER SA, www.kolporter.com.pl, e-mail: prenumerata.warszawa@kolporter.com.pl tel. 22 355-04-71 do 75

GARMOND PRESS SA, e-mail: prenumerata.warszawa@garmondpress.com.pl tel. 22 837-30-08

Subscription orders for all magazines published in Poland available through the local press distributors or directly through:

Foreign Trade Enterprise ARS POLONA SA, ul. Obrońców 25, 03-933 Warszawa www.arspolona.com.pl,e-mail: arspolona@arspolona.com.pl 